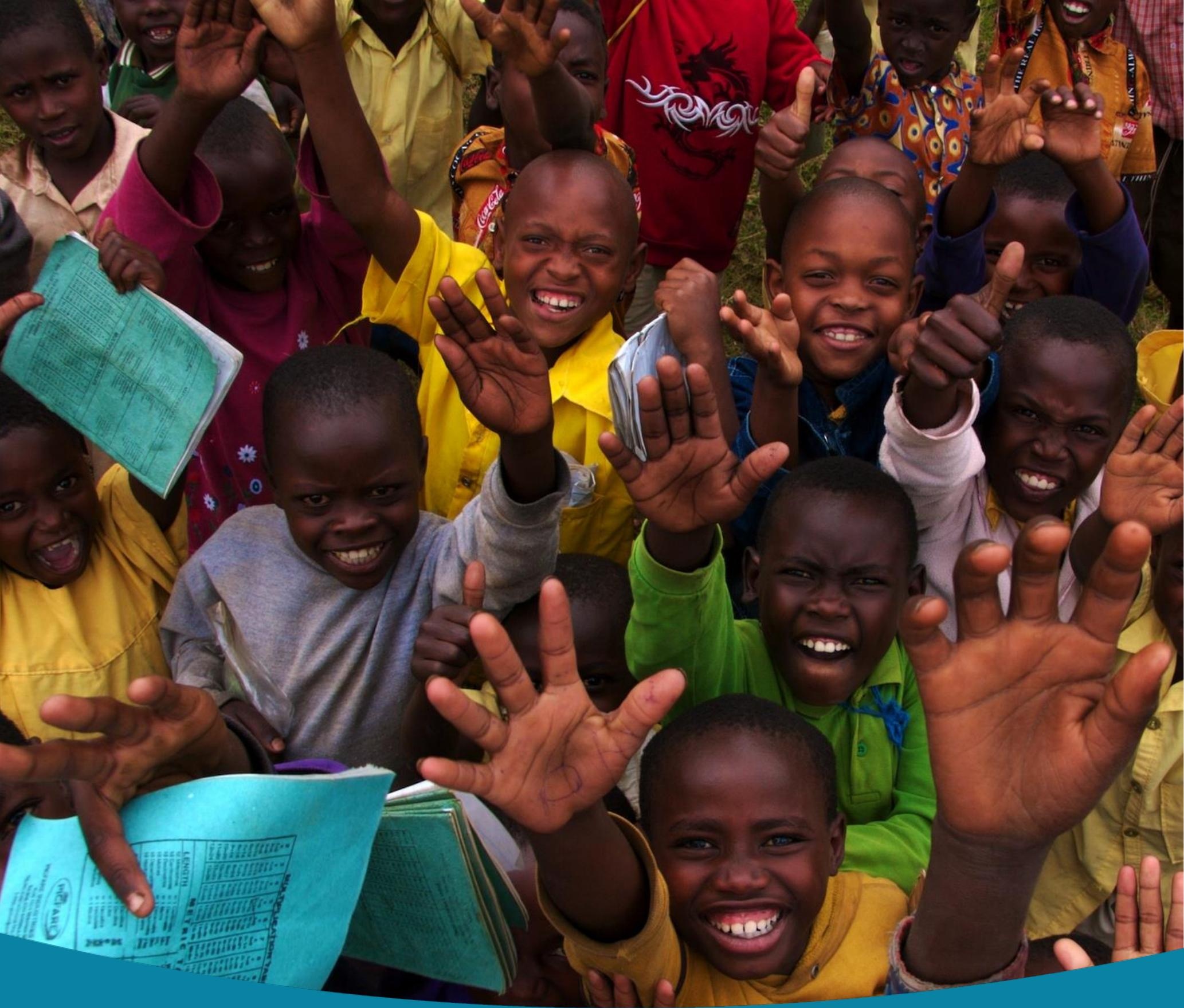




\section{About CEDIL}

The Centre of Excellence for Development Impact and Learning (CEDIL) is an academic consortium supported by the UK government through UK Aid. The mission of the Centre is to test innovative methodologies in evaluation and evidence synthesis and promote evidence-informed development. CEDIL-supported projects fall into three programmes of work: evaluating complex interventions, enhancing evidence transferability, and increasing evidence use.

\section{CEDIL syntheses working papers}

The CEDIL Syntheses Working Paper series publishes innovative research syntheses of the impact of interventions in low- and middle-income countries in the form of evidence and gap maps, systematic reviews, meta-analyses and other synthesis products.

\section{About this working paper}

This paper is a report on a country evaluation map that makes existing development evaluations in Uganda accessible to users for supporting evidence-informed decisionmaking across government, development partners, and civil society.

Suggested citation: White H., Lubanga T., Rathinam F., Taremwa R., Kachero B., Otike C., Apunyo R., Siddiqui Z., Joshi A., Saran A., and Obuku E. 2021. Development evaluations in Uganda 2000-2018: A Country Evaluation Map. CEDIL Syntheses Working Paper 1. Oxford: Centre of Excellence for Development Impact and Learning (CEDIL). Available at:

https://doi.org/10.51744/CSWP1

Cover design: PhilDoesDesign

Cover picture credit: "Hands Up" by SimonWhitaker is licensed under CC BY-NC 2.0

Copyright: (c) 2021 This is an open-access article distributed under the terms of the Creative Commons Attribution License, which permits unrestricted use, distribution, and reproduction in any medium, provided the original author and source are credited. 


\title{
Development evaluations in Uganda 2000-2018: A Country Evaluation Map
}

\author{
Authors \\ Howard White \\ The Campbell Collaboration \\ Timothy Lubanga \\ Office of the Prime Minister, Government of Uganda \\ Francis Rathinam \\ Athena Infonomics \\ Roland Bless Taremwa \\ Office of the Prime Minister, Government of Uganda \\ Benjamin Kachero \\ Office of the Prime Minister, Government of Uganda
}

Caroline Otike

Africa Centre for Systematic Reviews and Knowledge Translation, Makerere University

Robert Apunyo

Africa Centre for Systematic Reviews and Knowledge Translation, Makerere University

Zeba Siddiqui

International Initiative for Impact Evaluation

Anagha Joshi

Australian Institute of Family Studies

Ashrita Saran

Campbell South Asia

Ekwaro Obuku

Africa Centre for Systematic Reviews and Knowledge Translation, Makerere University

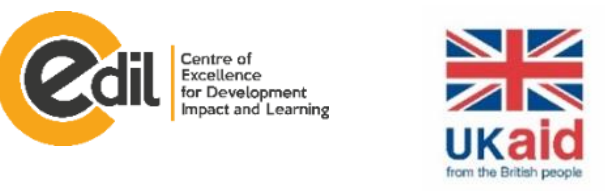




\section{Contents}

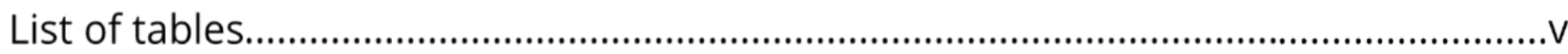

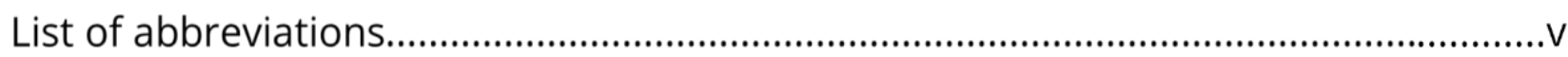

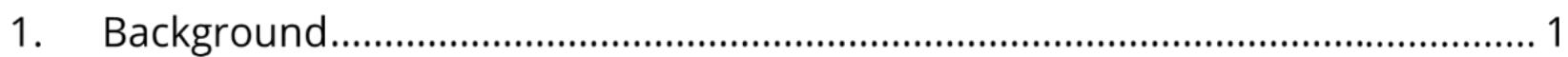

1.1 The purpose of the evaluation map .................................................................... 1

1.2 Scope of the evaluation map ................................................................................ 1

1.3 Why it is important to develop the evaluation map ............................................2

1.4 Existing EGMs and/or relevant systematic reviews..........................................2

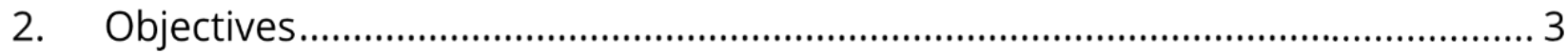

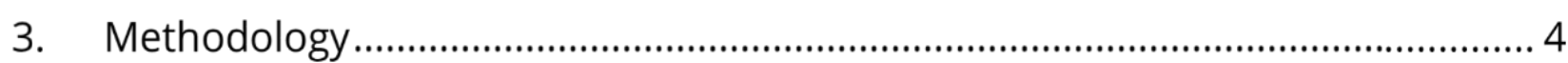

3.1 Defining country evaluation maps ................................................................. 4

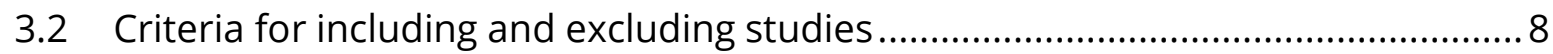

4. Stakeholder engagement in preparation of the map ....................................... 12

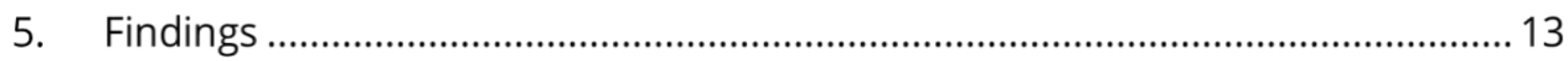

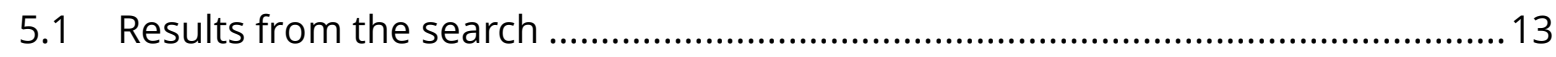

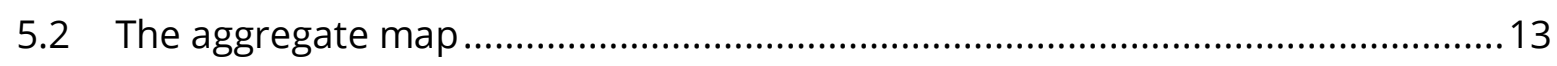

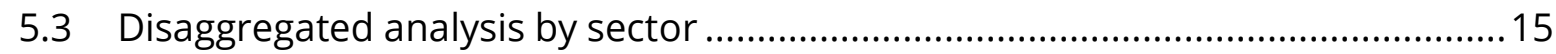

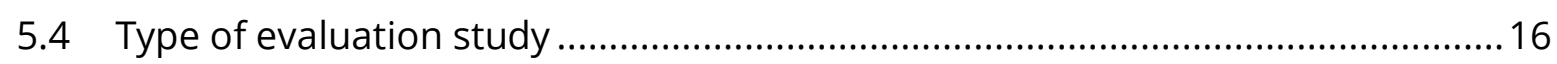

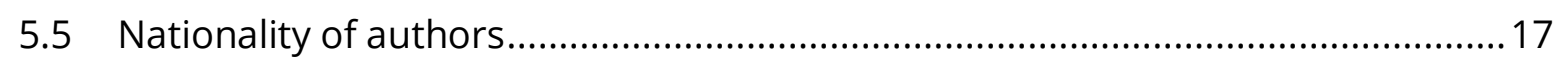

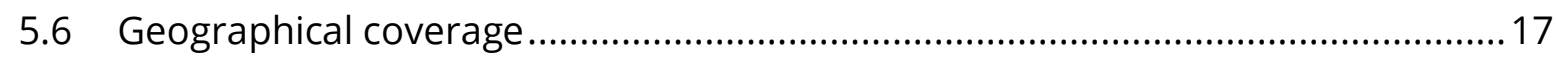

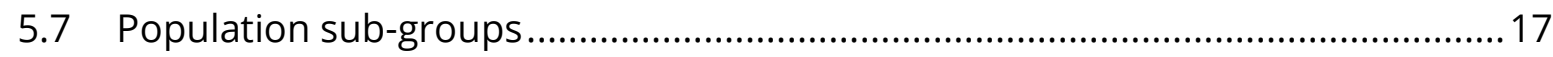

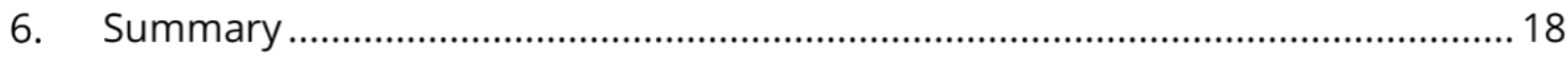

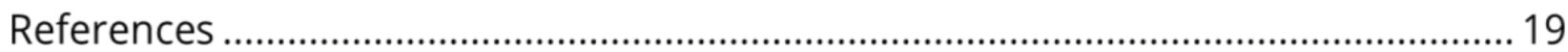

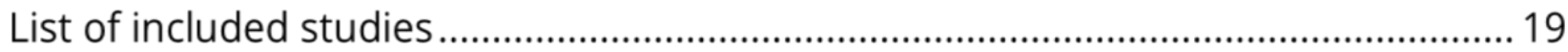

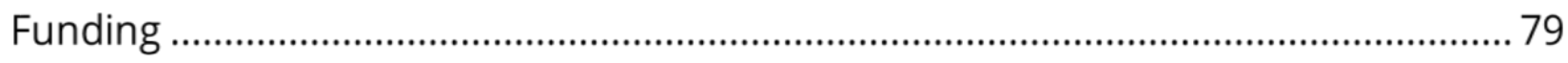

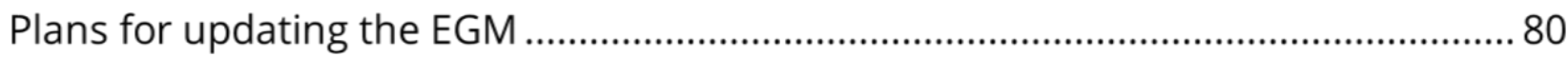




\section{List of tables}

Table 1: Intervention categories and sub-categories....................................................... 5

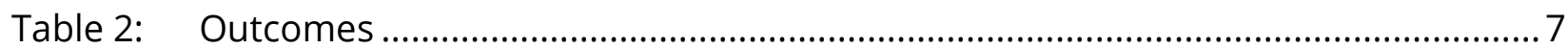

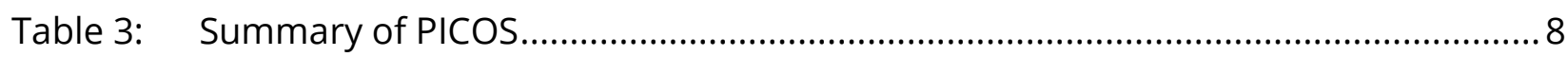

Table 4: Source of studies in the evaluation map ......................................................... 13

Table 5: $\quad$ Aggregate map (number of studies) ….............................................................. 14

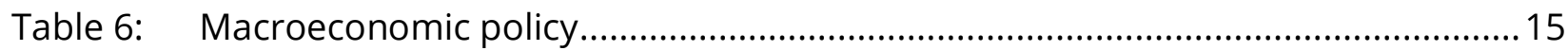

Table 7: Economic development evaluations by sub-sector ............................................. 15

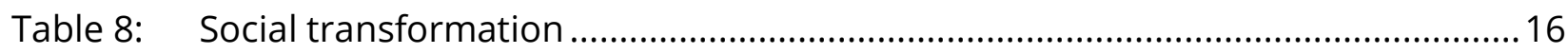

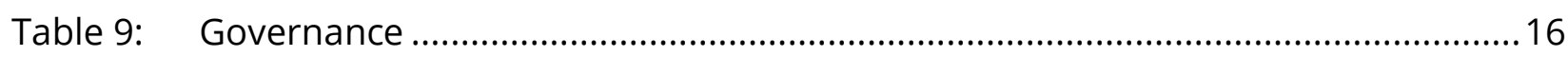

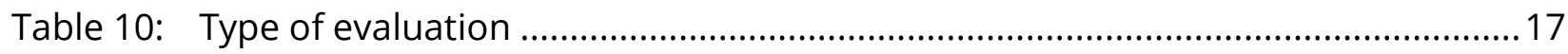

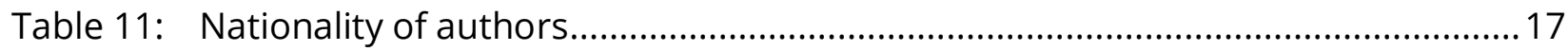

\section{List of abbreviations}

$\begin{array}{ll}\text { AfDB } & \text { African Development Bank } \\ \text { EGM } & \text { Evidence and gap map } \\ \text { M\&E } & \text { Monitoring and Evaluation } \\ \text { NGO } & \text { Non-governmental organisation } \\ \text { OECD } & \text { Organisation for Economic Co-operation and Development } \\ \text { OPM } & \text { Office of the Prime Minister } \\ \text { SDGS } & \text { Sustainable Development Goals } \\ \text { UNDP } & \text { United Nations Development Programme } \\ \text { UNICEF } & \text { United Nations Children's Fund } \\ \text { USAID } & \text { US Agency for International Development } \\ \text { VNR } & \text { Voluntary National Review }\end{array}$




\section{Background}

\subsection{The purpose of the evaluation map}

Evaluations are intended to serve two purposes: accountability and lesson learning. The lesson learning function of evaluations is a public good. Lessons from one programme can inform decisions about a similar programme elsewhere. However, this lesson learning function is undermined by the fact that there is low discoverability of completed evaluations. Many have a short shelf life, not reaching an audience beyond the few people with a direct interest in that specific evaluation. Hence, while there is an increasing drive to use evidence, and more funding to generate new evidence, much existing evidence goes unread and unused. For example, the formative and process evaluations routinely conducted by large government and donor-funded programmes are generally not disseminated beyond the immediate stakeholder group and are generally not included in any databases. Similarly, researcher-driven impact evaluations, published in academic journals and working paper series, may not be easily available to policymakers.

This country evaluation map seeks to make recent development evaluations from Uganda visible and available in a single repository, identifying potential gaps in knowledge and opportunities for synthesising existing evidence for the use of policymakers in Uganda. Users can submit studies for inclusion in the map, thus giving the map a repository function.

The country evaluation is a specific type of evidence and gap map (EGM). EGMs take many forms; these can include maps of impact evaluations and effectiveness reviews but may also include process evaluations and mega maps which map just systematic reviews (Saran and White, 2018; White et al., 2020).

\subsection{Scope of the evaluation map}

The country evidence map will include all evaluations of development interventions implemented in Uganda from 2000 to 2018. 'Evaluation' is defined to include all major design types, i.e. formative, process, outcome, and impact evaluations. 'Development' is broadly defined to cover all interventions intended to either directly or indirectly improve the wellbeing of the Ugandan people. Technical studies (e.g. trials of new drugs to be used in other markets or testing new agricultural inputs) are excluded, although efficacy and effectiveness evaluations of the adoption and use of these technologies under field conditions are included. 


\subsection{Why it is important to develop the evaluation map}

A preliminary scoping search suggested that there have been at least 500 evaluations of development interventions in Uganda since 2000. Most of these studies are not known to potential users. Moreover, as the number of evaluations grows, so does the scope for learning from the body of evidence contained in a group of studies on a particular issue. It is widely accepted that rigorous evidence synthesis of all available, relevant evidence is a superior approach compared to taking decisions based on one study that may prove to be an exception or on literature reviews based on non-systematic selection of studies.

\subsection{Existing EGMs and/or relevant systematic reviews}

To our knowledge this will be the first country evaluation map for all development evaluations for a single country. The Africa Centre for Evidence has published sectorspecific maps for South Africa, e.g. for human settlements. ${ }^{1}$ Some countries, including Uganda, have a national evaluation database, but the studies in the database have not been mapped. ${ }^{2}$ Moreover, such databases are not based on a systematic search.

1 https://africacentreforevidence.org/human-settlements-evidence-map description/\#

2 The Uganda database has not been maintained and there is not currently a working link to the database. 


\section{Objectives}

The primary objective of the Uganda country evaluation map is to make the existing evaluations accessible to users, so as to support evidence-informed decision-making across government, development partners, and civil society.

The secondary objectives are to:

(i) Identify gaps in available evidence, and clusters of evidence suitable for systematic reviews;

(ii) Raise awareness of the use of evidence in policy and practice;

(iii) Initiate discussions around evaluation trends in Uganda, and systemic effects on evaluation transparency and quality; and

(iv) Provide proof of concept for the approach and testing use of country evaluation maps, as this map will be the first country evaluation map covering all sectors.

The research question being addressed to support these objectives is: what is the extent of the evidence base of evaluations of development programmes in Uganda? 


\section{Methodology}

\subsection{Defining country evaluation maps}

Saran and White (2018) define EGMs as:

A systematic visual presentation of the availability of relevant evidence of effects for a particular policy domain. The evidence is identified by a search following a prespecified, protocol. Maps are accompanied by a descriptive report to summarise the evidence for stakeholders such as researchers, research commissioners, policy makers, and practitioners. Evidence maps summarise what evidence there is, not what the evidence says.

Similar to EGMs, country evaluation maps systematically search for relevant systematic reviews and primary studies based on a pre-specified protocol, and provide a graphical representation of available evidence. The scope of a country evaluation map includes all policy domains that affect the welfare of the people of the country, and include all types of evaluations, i.e. formative, process, outcome, and impact evaluations.

\subsubsection{Evaluation map framework}

The framework was developed through the following process:

Stage 1: Initial framework constructed through consultation of strategy and policy documents as identified above;

Stage 2: Consultation with the Office of the Prime Minister (OPM) of Uganda on the proposed framework;

- Stage 3: Piloting framework with 10-20 included studies. The framework was finalised once the first 20 studies were coded.

\subsubsection{Population}

The relevant population for this map is both the people (including refugees) and institutions of Uganda. Hence, all residents of Uganda are included. The Ugandan diaspora, including Ugandan refugees in other countries, are not included. Population sub-groups that are coded are: rural/urban, poor, people with disabilities, children, youth, aged, ethnic minorities, refugees, and conflict-affected persons. 


\subsubsection{Intervention}

The map covers all development interventions. The categorisation of the interventions follows the categories in Uganda's Vision 2040. ${ }^{3}$ The Vision has four main categories:

- Macroeconomic policies;

- Economic development;

- Social transformation;

- Governance.

The document text under each of these headings was used to identify sub-categories. For the initial coding some minor amendments were made to consolidate categories. As a result of the content found in studies, we relabelled two of the categories to better reflect what is in the studies:

- Economic development replaced Macroeconomic policies;

Sector development replaced Economic development;

Social transformation remained unchanged;

- Governance remained unchanged.

In addition, the sub-category 'Care and protection of vulnerable groups' has been replaced by the more commonly used term 'Social protection'. The final labels are shown in Table 1.

\section{Table 1: Intervention categories and sub-categories}

\begin{tabular}{|c|c|c|}
\hline Category & Sub-category & Description \\
\hline \multirow[t]{5}{*}{$\begin{array}{l}\text { Economic } \\
\text { development }\end{array}$} & Macroeconomic strategies & $\begin{array}{l}\text { Inflation policy. Government debt and } \\
\text { borrowing }\end{array}$ \\
\hline & Savings and investments & $\begin{array}{l}\text { Savings including savings groups. } \\
\text { Investment incentives }\end{array}$ \\
\hline & Financial services & Banking sector. Microfinance \\
\hline & Balance of payments & Exchange rate policy. Reserve management \\
\hline & Public finance & $\begin{array}{l}\text { Government revenue (taxation but not tariff } \\
\text { barriers) and expenditure (fiscal policy) }\end{array}$ \\
\hline \multirow{3}{*}{$\begin{array}{l}\text { Sector } \\
\text { development }\end{array}$} & Tourism & Internal and external tourism \\
\hline & $\begin{array}{l}\text { Agricultural and water } \\
\text { resources }\end{array}$ & $\begin{array}{l}\text { Agricultural development. Water resource } \\
\text { management (irrigation, watershed } \\
\text { development for agricultural purposes). } \\
\text { Includes rural roads }\end{array}$ \\
\hline & $\begin{array}{l}\text { Energy, minerals, oil and } \\
\text { gas }\end{array}$ & Energy sector \\
\hline
\end{tabular}

\section{${ }^{3}$ http://npa.ug/wp-content/themes/npatheme/documents/vision2040.pdf}




\begin{tabular}{|c|c|c|}
\hline Category & Sub-category & Description \\
\hline & Industry & $\begin{array}{l}\text { Industrial promotion and policy. Industrial } \\
\text { zones }\end{array}$ \\
\hline & Trade & $\begin{array}{l}\text { Imports and export policies and incentives, } \\
\text { including tariffs }\end{array}$ \\
\hline & $\begin{array}{l}\text { Science, technology, } \\
\text { engineering and } \\
\text { innovation (including } \\
\text { knowledge and ICT) }\end{array}$ & $\begin{array}{l}\text { R\&D. Incentives. Investment in telecoms and } \\
\text { IT }\end{array}$ \\
\hline & Labour force & $\begin{array}{l}\text { Labour market policy and interventions. } \\
\text { Employment programmes }\end{array}$ \\
\hline & Urban development & $\begin{array}{l}\text { Urban planning, investment in the urban } \\
\text { environment (except housing). Includes } \\
\text { urban transport and road safety }\end{array}$ \\
\hline & Land & Land policy such as land ownership rights \\
\hline \multirow[t]{7}{*}{$\begin{array}{l}\text { Social } \\
\text { transformation }\end{array}$} & $\begin{array}{l}\text { Population, health and } \\
\text { nutrition }\end{array}$ & $\begin{array}{l}\text { Population, health and nutrition including } \\
\text { water, sanitation, and hygiene }\end{array}$ \\
\hline & \begin{tabular}{|l|} 
Education and literacy \\
(including early childhood \\
development (ECD))
\end{tabular} & Schooling at all levels. Adult education \\
\hline & $\begin{array}{l}\text { Social protection (care } \\
\text { and protection of } \\
\text { vulnerable groups) }\end{array}$ & $\begin{array}{l}\text { Social safety nets such as pensions. Also } \\
\text { includes conditional cash transfers }\end{array}$ \\
\hline & Housing & Housing policies and programmes \\
\hline & National culture & Museums, theatre, etc. \\
\hline & $\begin{array}{l}\text { Gender equality and } \\
\text { women's empowerment }\end{array}$ & $\begin{array}{l}\text { Gender equality policies. Women's rights - } \\
\text { awareness raising, etc. }\end{array}$ \\
\hline & $\begin{array}{l}\text { Climate change, } \\
\text { environment and natural } \\
\text { resources }\end{array}$ & $\begin{array}{l}\text { Environmental and climate change, including } \\
\text { nature resource management }\end{array}$ \\
\hline \multirow[t]{6}{*}{ Governance } & Constitutional democracy & Constitutional framework \\
\hline & Rule of law & Justice and police interventions \\
\hline & $\begin{array}{l}\text { Electoral and political } \\
\text { processes }\end{array}$ & Support to national and local elections \\
\hline & $\begin{array}{l}\text { Transparency and } \\
\text { accountability }\end{array}$ & Support to free press. Anti-corruption \\
\hline & $\begin{array}{l}\text { Government effectiveness } \\
\text { and regulatory quality }\end{array}$ & $\begin{array}{l}\text { Institutional development for government } \\
\text { agencies and regulatory authorities }\end{array}$ \\
\hline & $\begin{array}{l}\text { Peace, security, and } \\
\text { defence }\end{array}$ & $\begin{array}{l}\text { Peace keeping and security interventions. } \\
\text { Post-conflict interventions }\end{array}$ \\
\hline
\end{tabular}




\subsubsection{Outcomes}

The outcomes are based on the Sustainable Development Goals (SDGs), again with some minor consolidation (see Table 2). The Government of Uganda has committed to developing a roadmap to achieve the SDGs, ${ }^{4}$ so the country evaluation map will be a useful tool in that work.

In order to reduce ambiguity in coding we combined some SDGs. The poverty and economic growth SDGs (1 and 8) are combined under 'Economic development'. This approach does not contradict the multi-dimensional nature of poverty since the whole point of the SDGs, and their predecessor Millennium Development Goals, is to emphasis outcomes other than economic ones; hence the other dimensions of poverty are captured across the SDGs, e.g. health in SDG3. Energy and industry are combined (SDGs 7 and 9) as energy falls under industry so the outcomes are closely related. SDGs 12-15 all relate to environmental outcomes and so are readily combined, which is one of the steps undertaken to limit the number of columns in which a single study is coded.

In one case we separate out the SDG - agriculture and nutrition. Nutrition outcomes may come from a range of interventions, some agricultural and some not. The outcomes that fell in the aggregated category will fall clearly in one or the other. For example, food security measured by number of meals a day falls under nutrition, whereas calorific equivalence of domestic food production falls under agriculture.

\section{Table 2: Outcomes}

Economic development (including poverty and employment) - SDGs 1 and 8

Sustainable agriculture - SDG 2

Nutrition - SDG 2

Health and wellbeing - SDG 3

Education - SDG 4

Gender - SDG 5

Water and sanitation - SDG 6

Energy, industry and infrastructure provision - SDGs 7 and 9

Urban development - SDG 11

Environmental sustainability - SDGs 12,13,14, and 15

Peace and justice - SDG 16

Global partnerships - SDG 17

Inequality - SDG 10

4 https://opm.go.ug/2018/09/22/opm-in-uganda-to-launch-sdgs-roadmap-in-october-2018/ 
Table 3 summarises the inclusion criteria for studies in the map. Following the standard approach, these inclusion criteria are defined according to the PICOS; that is:

- Population: who are the eligible target group for the interventions evaluated in the study?

- Intervention: what sort of interventions are eligible for inclusion?

- Comparison: what sort of comparison groups are eligible (applies only to effectiveness studies)?

- Outcomes: what outcomes are eligible for inclusion?

- Study designs: What study designs are eligible for inclusion?

\section{Table 3: Summary of PICOS}

\begin{tabular}{|l|l|}
\hline Population & Ugandan citizens or people resident in Uganda (including refugees) \\
\hline Intervention & $\begin{array}{l}\text { All interventions to increase the welfare of Ugandan citizens or people } \\
\text { resident in Uganda (including refugees), either directly or indirectly. } \\
\text { Excludes: studies that test a technology rather than adoption of a } \\
\text { technology }\end{array}$ \\
\hline Comparison & Not applicable \\
\hline Outcomes & All outcomes (as captured by SDGs), including intermediary outcomes \\
\hline Studies & $\begin{array}{l}\text { All evaluations of a socio-economic development intervention of any } \\
\text { evaluation design. Multi-country evaluation reports and reviews were } \\
\text { included provided the study had sufficient codable information clearly } \\
\text { related to Uganda }\end{array}$ \\
\hline
\end{tabular}

\subsection{Criteria for including and excluding studies}

\subsubsection{Types of study designs}

All evaluation designs will be included. The main typology is based on a modification of Scriven's (1967) distinction between formative and summative evaluations. Evaluations will be classified as being as one of five types:

- Formative evaluations: these are evaluations undertaken at the early stages of a programme or during a pilot to inform programme design;

- Impact evaluations: these are evaluations that make a quantitative assessment of the difference the intervention makes to the indicators of interest. Only studies with a comparison group, or which otherwise control for selection bias (e.g. instrumental variables) will be coded as impact evaluations. Before-versus-after studies with no comparison group will be coded as outcome evaluations (even if they make claims about impact). Impact evaluation designs will be coded as randomised controlled trials and other impact evaluations;

\footnotetext{
${ }^{5}$ Trials of new drugs or industry or scientific testing of, for example, communications equipment are not included. However, studies in which these products are used with intended end users are included.
} 
Process evaluations: ex -post assessments of the intervention, usually focusing on issues such as management and implementation and stakeholder perceptions. Process evaluations may be either qualitative or quantitative, in the latter case reporting data such as characteristics of programme participants and trends on outcomes;

- Outcome evaluations: report project area (treated population) outcomes before and after, or just after, the intervention with no comparison group. We do not consider such designs to be valid measures of impact so keep them separate from impact evaluations;

- Evaluation synthesis: studies summarising several evaluation studies from Uganda. This does not include multi-country studies for which Uganda is one case study, but studies summarising two or more evaluations undertaken in Uganda.

Since the inclusion criteria pertain to the evaluation of development interventions in Uganda, systematic reviews are not included in this map. However, synthesis of sets of Ugandan evaluations are included.

\subsubsection{Types of settings}

The map includes all evaluation studies undertaken in Uganda regardless of setting.

\subsubsection{Search strategy}

Evaluations, especially process and formative evaluations, are predominately grey literature published on agency websites rather than in academic journals. Therefore, a traditional search of academic databases will not identify many of these studies.

The country EGM thus uses a search strategy customised for different sources based on the source of the study and study type. There are four such sources:

- Evaluations commissioned by official development partners, such as the US Agency for International Development (USAID) and the World Bank (we call these externally commissioned evaluations);

Locally commissioned evaluations by government agencies;

- Evaluations commissioned by non-governmental agencies; and

- Impact evaluations that are searched for separately in the 3ie database, which is the largest single comprehensive source of impact evaluations.

Externally commissioned evaluations: the main development partners each have a global evaluation repository that can be searched by country, hence allowing identification of Ugandan studies. The main such repositories to be searched are:

- United Nations Development Programme (UNDP) Evaluation Resource Centre, selecting country Uganda: https://erc.undp.org/i

USAID's Development Experience Clearinghouse, selecting evaluations (Final Evaluation Report and Special Evaluation) and then Uganda:

https://dec.usaid.gov/dec/content/evaluations.aspx; 
United Nations Children's Fund (UNICEF) evaluation database, selecting Uganda: www.unicef.org/evaldatabase/;

World Bank documents and reports (advanced search), selecting Uganda and a number of document types (impact evaluation, project performance audit/assessment report, project/implementation completion report, country assistance evaluation, sector and thematic evaluation): http://documents.worldbank.org/curated/en/home;

- Other official agencies, such as Sida, deposit their reports in the Organisation for Economic Co-operation and Development's (OECD) Development Assistance Committee Evaluation Research Centre, which is searched for Uganda: www.oecd.org/derec/?hf=5\&b=0\&s=score.

Finally, the 3ie impact evaluation repository (www.3ieimpact.org/evidence-hub/impactevaluation-repository) is searched for impact evaluations, using country Uganda.

Where the database allows a data range then the search is for 2000 -. If that is not possible then records pre-2000 were removed by manual screening.

Locally commissioned studies: To identify locally commissioned studies, staff of the Monitoring and Evaluation (M\&E) Department of OPM) wrote to the evaluation sections of all government agencies to ask them to supply evaluations completed in the last 10 years.

NGO-commissioned studies: These are grey literature that will not be identified through the usual databases. Hence, we searched Google and Google Scholar using the very general search string 'Uganda evaluation' (not an exact string), applying the $>=2000$ date range. Piloting showed that this approach did identify NGO-commissioned studies and Masters thesis not already included (with limited duplication of studies that are included from the search of repositories listed above). We also included names of some of the major nongovernmental organisations (NGOs) working in Uganda in the search string, e.g. ActionAid, Aga Khan Foundation, CARE, Concern, Heifer International, Hunger Project, International Rescue Committee, Oxfam, PANOS Eastern Africa, PATH, Save the Children, Sightsavers International, Water Aid, Worldwide Fund for Nature, and World Vision.

In addition to the above, it is expected that further evaluations will be submitted as a result of dissemination of the Evaluation Map.

It is recognised that this is not a full search to the standards of the Campbell Collaboration. Such a search would include a database search and a search of Masters and PhD theses from the main universities in Uganda. This search is not possible given the budget constraints of this map, but will be carried out if further funds become available. If that is possible we will also compare the results from this customised quick search to a full database search.

\subsubsection{Screening and selection of studies}

The screening and coding tools were developed based on the framework and piloted on a set of studies from across sources. Staff from Makerere and OPM received training in screening and coding to carry out the bulk of the work. Screening was conducted either in the 
databases themselves, in an Excel download of the search results, or using EPPI-Reviewer depending on the source. Where search results could be downloaded to a spreadsheet, screening was performed on the spreadsheet. If not, one screener screened online results, entering accepted studies into EPPI-Reviewer where they were rescreened by two screeners. All screening and coding was done by two researchers independently, with third-party reconciliation.

\subsubsection{Data extraction, coding, and management}

The studies were coded to extract bibliographic information, and the interventions, outcomes, and filters reported above. Coding was done in duplicate with third-party reconciliation.

\subsubsection{Units of analysis}

The units of analysis for the map are the individual studies where each entry represents a combination of an SDG and a type of evaluation. However, a single study may be entered multiple times depending on issues covered and study design employed (e.g., a study may count as both an impact evaluation and a process evaluation). That is, a single study may be coded under more than one intervention sub-category and more than one outcome if appropriate.

\subsubsection{Quality appraisal}

Critical appraisal will not be undertaken at this stage, but is considered for future editions of the map should funding become available.

\subsubsection{The online map}

An interactive online version of the map is generated using EPPI-Mapper. ${ }^{6}$ The map includes a link to each study. Since many of the studies in the map are grey literature it is a challenge to ensure all links continue to work if the study does not have a DOI. All links will be checked each time the map is updated.

\subsubsection{Dissemination and use}

Dissemination and use is expected to come from:

- Co-creation of the map with the OPM and the Africa Centre for Systematic Reviews, Makerere University;

- Engagement with the Uganda Evaluation Association so the map is known and used by their members;

- Promoting the map to the Uganda Management Institute for use on the diploma in M\&E.

\section{${ }^{6}$ https://eppi.ioe.ac.uk/cms/Default.aspx?tabid=3790}




\section{Stakeholder engagement in preparation of the map}

This framework for the map was developed through a consultation process. The initial framework was constructed through consultation of strategy and policy documents and OPM. The framework and later the draft and final reports were discussed with the Advisory Group for their inputs and feedback. 


\section{Findings}

\subsection{Results from the search}

The search was conducted in January and February 2019. The 3ie database is updated quarterly on a sectoral basis, so included studies are likely to be from early 2018 and before.

Table 4 shows the databases searched and number of studies in each database. We identified 617 evaluation reports. All included studies are published. Of these, just under $60 \%$ are reports and working papers and $40 \%$ are journal papers (there is just one exception, which is a dissertation).

Table 4: Source of studies in the evaluation map

\begin{tabular}{|l|c|c|}
\hline Source & Located & Included \\
\hline UNDP & 45 & 45 \\
\hline UNICEF & 16 & 16 \\
\hline 3ie database & 220 & 220 \\
\hline African Development Bank (AfDB) & 18 & 11 \\
\hline OECD DEReC & 88 & 25 \\
\hline World Bank & 79 & 79 \\
\hline USAID & 139 & 139 \\
\hline Grey literature (google) & 67 & 73 \\
\hline OPM manual search & 20 & 20 \\
\hline Total & 692 & 617 \\
\hline
\end{tabular}

Given the customised search approach, all or nearly all studies found were eligible for inclusion. The exception was the OECD DEReC, where reports were excluded either because they were multi-country studies with insufficient information on Uganda to be included or duplicates of studies found in other repositories. In the case of AfDB, the table captures screening out by date, which was part of the search in other cases. In the case of the Google search, 'located' refers to those identified as eligible by screening and uploaded to EPPIReviewer, of which four were then excluded on rescreening.

\subsection{The aggregate map}

Table 5 shows the 'aggregate map', i.e. the total number of studies by intervention and outcome categories (the map is transposed compared to the online map so as to fit on the page). The colour coding is based on the arbitrary thresholds of: (1) well-evidenced area: 20 or more studies; (2) moderately evidenced area: 10-19 studies; and (3) poorly evidenced area: fewer than 10 studies. 
Table 5: Aggregate map (number of studies)

\begin{tabular}{|c|c|c|c|c|c|}
\hline Code & $\begin{array}{l}\text { Macroeconomic } \\
\text { policy }\end{array}$ & $\begin{array}{c}\text { Economic } \\
\text { development }\end{array}$ & $\begin{array}{c}\text { Social } \\
\text { transformation }\end{array}$ & Governance & Total \\
\hline $\begin{array}{l}\text { Economic development (including poverty } \\
\text { and employment) - SDGs } 1 \text { and } 8\end{array}$ & 73 & 59 & 37 & 16 & 123 \\
\hline Nutrition - SDG 2 & 3 & 6 & 16 & 1 & 17 \\
\hline Sustainable agriculture - SDG 2 & 9 & 45 & 14 & 3 & 44 \\
\hline Health and wellbeing - SDG 3 & 22 & 18 & 285 & 18 & 297 \\
\hline Gender - SDG 5 & 8 & 8 & 37 & 7 & 42 \\
\hline Water and sanitation - SDG 6 & 6 & 24 & 13 & 5 & 26 \\
\hline $\begin{array}{l}\text { Energy, industry and infrastructure } \\
\text { provision - SDGs } 7 \text { and } 9\end{array}$ & 19 & 47 & 8 & 3 & 42 \\
\hline Urban development - SDG 11 & 3 & 8 & 3 & 2 & 8 \\
\hline Global partnerships - SDG 17 & 7 & 4 & 6 & 5 & 12 \\
\hline Inequality - SDG 10 & 5 & 6 & 15 & 6 & 19 \\
\hline Total & 93 & 151 & 412 & 65 & 617 \\
\hline
\end{tabular}


The most heavily populated cell by far is the effect of social transformation interventions on health and wellbeing outcomes, with 285 studies. This reflects the preponderance of health research in the impact evaluation field. There are 13 other well-evidenced cells, five of which lay in the social transformation column, with each of education, gender and governance being well-evidenced. At the outcome level, economic is generally wellevidenced (being so for three of the four intervention categories). Finally, environmental sustainability, sustainable agriculture, energy and infrastructure and water and sanitation are well-evidenced for selected cells. More detail is reported on these cells below.

There are a reasonable number of moderately populated cells, especially in the social transformation column, but also including agriculture, education, governance, energy, and environmental sustainability. Nonetheless, there are some notable gaps, in particular a lack of studies related to nutrition, urban development, and inequality outcomes. In addition, the focus of many governance intervention evaluations appears to be mainly on governance outcomes, and much less on how these interventions affect a broader range of outcomes.

\subsection{Disaggregated analysis by sector}

Macroeconomic policy evaluations are reasonably spread across all sectors except balance of payments (Table 6). Evaluations of financial services and savings are not necessarily evaluations of interventions at the macro level; they also include microfinance interventions and savings groups and other interventions to support savings.

\section{Table 6: Macroeconomic policy}

\begin{tabular}{|l|c|c|}
\hline & Count & \% \\
\hline Financial services & 34 & 36.6 \\
\hline Savings and investments & 22 & 23.7 \\
\hline Macroeconomic strategies & 19 & 20.4 \\
\hline Public finance & 15 & 16.1 \\
\hline Balance of payments & 3 & 3.2 \\
\hline
\end{tabular}

Nearly half of the economic development intervention evaluations relate to agriculture and water resources. There are also many studies related to science, energy, and transport. Areas where more evaluations may have been expected given the importance of the issue are labour force, urban development, and land.

Table 7: Economic development evaluations by sub-sector

\begin{tabular}{|l|c|c|}
\hline Sub-category & Count & \% \\
\hline Agricultural and water resources & 73 & 48.3 \\
\hline $\begin{array}{l}\text { Science, technology, engineering, and innovation } \\
\text { (including knowledge and ICT) }\end{array}$ & 23 & 15.2 \\
\hline Energy, minerals, oil and gas & 18 & 11.9 \\
\hline
\end{tabular}




\begin{tabular}{|l|c|c|}
\hline Sub-category & Count & \% \\
\hline Transport infrastructure & 18 & 11.9 \\
\hline Industry & 8 & 5.3 \\
\hline Labour force & 7 & 4.6 \\
\hline Urban development & 6 & 4.0 \\
\hline Land & 5 & 3.3 \\
\hline Trade & 3 & 2.0 \\
\hline Tourism & 2 & 1.3 \\
\hline
\end{tabular}

Two-thirds of social transformation interventions are in the area of health, but there are also a reasonable number of evaluation studies across all other sub-sectors except housing, for which there are only three studies (Table 8).

Table 8: Social transformation

\begin{tabular}{|l|c|c|}
\hline & Count & \% \\
\hline Population, health, and nutrition & 275 & 66.7 \\
\hline Education and literacy (including ECD) & 74 & 18.0 \\
\hline Care and protection of vulnerable groups & 69 & 16.7 \\
\hline Climate change, environment, and natural resources & 39 & 9.5 \\
\hline Gender equality and women's empowerment & 34 & 8.3 \\
\hline Housing & 3 & 0.7 \\
\hline
\end{tabular}

The largest area for governance intervention evaluations is government effectiveness (Table 9), which includes evaluations assessing capacity-building activities for government officials. However, there are also a number of evaluations across all other sub-categories.

Table 9: Governance

\begin{tabular}{|l|c|c|}
\hline & Count & \% \\
\hline Government effectiveness and regulatory quality & 22 & 33.8 \\
\hline Transparency and accountability & 18 & 27.7 \\
\hline Peace, security, and defence & 17 & 26.2 \\
\hline Rule of law & 12 & 18.5 \\
\hline Constitutional democracy & 9 & 13.8 \\
\hline Electoral and political processes & 8 & 12.3 \\
\hline
\end{tabular}

\subsection{Type of evaluation study}

Nearly $60 \%$ of studies contain process evaluation evidence and over $40 \%$ impact evaluations. There are very few formative evaluations, which may reflect that such studies often do not make it to the public domain. 
Table 10: Type of evaluation

\begin{tabular}{|l|c|c|}
\hline & Count & \% of studies \\
\hline Impact evaluation & 267 & 43 \\
\hline Process evaluation & 351 & 57 \\
\hline Formative evaluation & 21 & 3 \\
\hline Outcome evaluation & 24 & 4 \\
\hline Total studies & 617 & \\
\hline
\end{tabular}

Very notably, we found no synthesis of Ugandan evaluations. While we found several studies that included Uganda as one of several countries in an evaluation of a specific intervention, little or no attention appears to have been paid to learning from the bodies of evidence.

\subsection{Nationality of authors}

Over $40 \%$ of included studies have no Ugandan author and over a quarter a non-Ugandan lead author. Fewer than 15\% have an all Ugandan team, and a similar amount have a Ugandan lead author with non-Ugandan team members.

Table 11: Nationality of authors

\begin{tabular}{|l|c|c|}
\hline & Count & $\begin{array}{c}\text { \% of total } \\
\text { studies }\end{array}$ \\
\hline Ugandan lead author with non-Ugandan authors & 88 & 14.3 \\
\hline Ugandan authors with non-Ugandan lead & 162 & 26.3 \\
\hline No Ugandan authors & 262 & 42.5 \\
\hline All Ugandan authorship & 85 & 13.8 \\
\hline Authors not named & 22 & 3.6 \\
\hline Total & 617 & \\
\hline
\end{tabular}

\subsection{Geographical coverage}

Just over half of the studies have national coverage, though that may be overstated as it may include studies for which the geographical focus was unclear. For those evaluations for which geographical focus could be determined, most are in the central region, which includes Kampala, followed by Northern, which has been an area of donor focus on account of its post-conflict status.

\subsection{Population sub-groups}

There are many studies on children (118 studies) and youth (96) but also a fair number on the aged (41). There are also many studies for conflict-affected persons (66), though fewer for refugees (14). There are very few evaluations related to people with disabilities (just four). 


\section{Summary}

The Uganda country evaluation map puts in the public domain 617 evaluations of development interventions in Uganda, which were published in 2000 or later.

A main purpose of the map is to increase the discoverability and therefore use of the evaluation evidence base. The map has been co-produced with both the OPM and researchers at the Africa Centre for Systematic Reviews and Knowledge Translation. The OPM has been using the map as part of its planning process (see below). The studies in the map have been one source for a scoping study of research on women's groups in Uganda. The scoping review included studies with any research design; the map provided seven relevant studies, four of which had not been located from other sources. ${ }^{7}$

The country evaluation map was first presented at the 2019 Evaluation Week. As noted above, the results show a concentration of studies undertaken under health and well being (SDG 3). As a follow up, the OPM embarked on developing an Evaluation Agenda for the health sector (with support from CLEAR-AA). The draft Evaluation Agenda is being finalised, and will be validated by April 2021.

The OPM also led Uganda's Voluntary National Review (VNR) of the implementation of the SDGs, with the report being presented by the Minister for General Duties at the UN High Level Political Forum in October 2020. The VNR was predominantly a desk review of existing evidence on SDG implementation. The OPM used the EGM to identify recent relevant studies across the different SDGs. ${ }^{8}$

The OPM has also embarked on developing the Evaluation Agenda for the National Development Plan III (2020/21-2024/25), which will be structured around the 18 programmes of the Plan. This presents another opportunity to utilise the map.

These examples will hopefully encourage other uses - such as learning lessons from past experience as to how best respond to the crisis caused by COVID-19.

One of the benefits of co-production is greater local dissemination and utilisation of the research product. At the same time, the most important finding of the map is that there are many opportunities to synthesise national studies to learn sector-specific lessons. However, the map shows that that sort of research has not been undertaken - even though there are many cells with good or moderate levels of evidence. This map provides a starting point for such research being undertaken to inform policy and programme design.

\footnotetext{
7 The map is not yet published but details may be found here https://womensgroupevidence.org/ourwork/country-specific-evidence-synthesis-on-women-s-groups-in-Uganda.

8 https://sdgs.opm.go.ug/vnr-presentation-to-the-high-level-political-forum/ 


\section{References}

Saran A. and White H. (2018). Evidence and gap maps: A comparison of different approaches. Campbell Systematic Reviews, 14: 1-38. https://doi.org/10.4073/cmdp.2018.2

Scriven, M. (1967). 'The methodology of evaluation', pp. 39-83 in R.W. Tyler, R.M. Gagne, and M. Scriven (eds.) Perspectives of Curriculum Evaluation. Chicago, IL: Rand McNally.

White H., Albers B., Gaarder M., et al. (2020). Guidance for producing a Campbell evidence and gap map. Campbell Systematic Reviews, 16:e1125. https://doi.org/10.1002/cl2.1125

\section{List of included studies}

Abola C. (2018). Evaluation of the GoU Rural Water Supply and Sanitation Programme (RWSSP) 2010 - 2017. Kampala: Office of the Prime Minister - Uganda, pp.64. Available at: http://www.mwe.go.ug/sites/default/files/library/SPR\%202018\%20\%20FINAL.pdf.

Abola C, Omach P, Anena C, Ochen A E, and Ateenyi B. (2009). Evaluation of Norwegian Development Cooperation through Norwegian Non-Governmental Organisations in Northern Uganda (2003-2007). Oslo: NORAD: Norad, pp.152. Available at: http://www.oecd.org/countries/uganda/42886936.pdf.

Abramsky T, Devries K, Kiss L, Nakuti J, Kyegombe N, Starmann E, Cundill B, Francisco L, Kaye D, Musuya T, Michau L, and Watts C. (2014). Findings from the SASA! Study: a cluster randomized controlled trial to assess the impact of a community mobilization intervention to prevent violence against women and reduce HIV risk in Kampala, Uganda. BMC Medicine, 12(1), pp.122.

Abramsky T, Devries K M, Michau L, Nakuti J, Musuya T, Kiss L, Kyegombe N, and Watts C. (2016). Ecological pathways to prevention: How does the SASA! community mobilisation model work to prevent physical intimate partner violence against women? BMC Public Health, 16(1), pp.339.

Abramsky T, Devries K M, Michau L, Nakuti J, Musuya T, Kyegombe N, and Watts C. (2016). The impact of SASA! a community mobilisation intervention on women's experiences of intimate partner violence: secondary findings from a cluster randomised trial in Kampala, Uganda. Journal of Epidemiology and Community Health, 70(8), pp.818-825.

Abubaker B, Berhanu G, Abdulhamid I, Kumbi S, Lulseged S, Mengistu Y, Bhore A V, Bhosale R, Varadhrajan V, Gupte N, Jayagowri S, Suryavanshi N, Tripathy S, Mmiro F, Mubiru M, Onyango C, Taylor A, Musoke P, Nakabiito C, and Abashawl A. (2008). Extended-dose nevirapine to 6 weeks of age for infants to prevent HIV transmission via breastfeeding in Ethiopia, India, and Uganda: an analysis of three randomised controlled trials. The Lancet, 372(9635), pp.300-313. 
Academy for Educational Development. (2007). Fuel Efficient Stove Programs in IDP settings - Summary Evaluation Report, Uganda. Washington D.C: United States Agency for International Development, pp.39. Available at:

https://www.google.com/url?sa=t\&rct=j\&q=\&esrc=s\&source=web\&cd=1\&ved=2ahUKE wig1 teG9f_IAhWI-

KQKHU7jDBgQFjAAegQIAxAC\&url=https\%3A\%2F\%2Fpdf.usaid.gov\%2Fpdf_docs\%2FPd acm098.pdf\&usg=AOvVaw0r8MSpNkNeXlqwVAYAKn5E.

Achath S, and Gunaratne L. (2009). Implementation Completion and Results Report for Uganda - Energy for Rural Transformation Project. Washington D.C: World Bank, pp.106. Available at:

http://documents1.worldbank.org/curated/en/414141468108858762/pdf/ICR12880Re vise1 revious0records10111.pdf.

Acworth J, and Ratter A. (2005). Conservation of afro-montane forest \& mountain gorillas in a landscape context: 'life of project' performance evaluation. Washington D.C: USAID, pp.95. Available at: https://pdf.usaid.gov/pdf_docs/PDACG165.pdf

Adelman S, Alderman H, Gilligan D O, and Lehrer K. (2008). Evaluation of the Irish Aid (Uganda) Country Strategy Paper 2007-2009. Washington D.C: World Bank, pp.2. Available at: https://www.semanticscholar.org/paper/The-impact-of-alternative-foodfor-education-on-and-Gilligan-Leher/b085f2ec8302553d9c3eb462a5a9df9d2c823249.

Adorna C, and Broughton B. (2012). UNDAF Uganda 2010-2014 Mid Term Review. New York: United Nations Development Programme (UNDP), pp.108. Available at: https://erc.undp.org/evaluation/documents/detail/7150.

Advanced marketing systems. (2017). Final report: evaluation of the northern Karamoja growth, health and governance project in Karamoja Region, Uganda. Washington D.C: USAID, pp.107. Available at: https://pdf.usaid.gov/pdf_docs/PA00SVZZ.pdf.

Agha S, Balal A, and Ogojo O F. (2002). The impact of a microfinance program on client perceptions of the quality of care provided by private sector midwives in Uganda. Health Services Research, 39(6), pp.2081-2100.

AH Consulting. (2017). Mid-term evaluation of the Kampala institutional and infrastructure development project (KIIDP 2). Kampala: Kampala Capital City Authority. Available at: http://documents1.worldbank.org/curated/pt/541101523286845586/pdf/KIIDP-IIAudited-Financial-Statements-June-2017.pdf.

Akelem E, Otikal K, Otutu N, and Okiror E. (2018). Amuria District Local Government District Development Plan - Mid Term Review. Amuria: Amuria District Local Government. Available at:

https://www.amuria.go.ug/sites/files/Amuria\%20Midterm\%20Review\%20Report\%2020 18.pdf.

Alamo S, Wabwire M F, Ekoru K, Sunday P, Laga M, and Colebunders R L. (2012). TaskShifting to Community Health Workers: Evaluation of the Performance of a Peer-Led Model in an Antiretroviral Program in Uganda. AIDS Patient Care and STDs, 26(2), pp.101-107. 
Alastair A, Bree A, Lindsay S, Eirini F, Okot B, McCollister F, and Boothby N. (2011). The impact of the school-based Psychosocial Structured Activities (PSSA) program on conflict-affected children in northern Uganda. Journal of Child Psychology and Psychiatry, 52(11), pp.1124-1133.

Alderman H. (2007). Improving Nutrition through Community Growth Promotion: Longitudinal Study of the Nutrition and Early Child Development Program in Uganda. World Development, 35(8), pp.1376-1389.

Alderman H, Gilligan D O, and Lehrer K. (2012). The Impact of Food for Education Programs on School Participation in Northern Uganda. Economic Development and Cultural Change, 61(1), pp.187-218.

Alderman H, Konde-Lule J, Sebuliba I, Bundy D, and Hall A. (2006). Effect on weight gain of routinely giving albendazole to preschool children during child health days in Uganda: cluster randomised controlled trial. BMJ.

Alfonso Y N, Bishai D, Bua J, Mutebi A, Mayora C, and Ekirapa K E. (2015). Cost-effectiveness analysis of a voucher scheme combined with obstetrical quality improvements: quasi experimental results from Uganda. Health Policy and Planning, 30 (1), pp.88-99.

Allan king and associates. (2004). Final evaluation of the Dairy Consortium Activity 2001 2004: Uganda -- final report. Washington D.C: USAID, pp.74. Available at: https://pdf.usaid.gov/pdf_docs/PDACG162.pdf.

All-Yirga G, and Akintunde A. (2006). Multinational Fifth Line of Credit to East African Development Bank (EADB) Project Performance Evaluation Report. Abidjan: African Development Bank, pp.59. Available at: http://idev.afdb.org/sites/default/files/Evaluations/2020-03/Multinational\%20\%20Fifth\%20Line\%20of\%20Credit\%20to\%20East\%20African\%20Development\%20Bank \%20\%28EADB\%29\%20-\%20PPER.pdf.

Alsan M M, and Cutler D M. (2013). Girls' education and HIV risk: Evidence from Uganda. Journal of Health Economics, 32 (5), pp.863-872.

Alvesson H M, Bertoncino C, and Priyadarshi M. (2006). Implementation completion report for Uganda - Nutrition and Early Childhood Development Project. Washington D.C: World Bank, pp.72. Available at: http://documents.worldbank.org/curated/en/652311468113067497/Uganda-Nutritionand-Early-Childhood-Development-Project.

Ambroso G, Meier-Ewert GS, Parker L, and Richardson L. (2016). Evaluation of UNHCR's Response to the L3 South Sudan Refugee Crisis In Uganda and Ethiopia. Geneva: UNHCR, pp.139. Available at: https://data2.unhcr.org/en/documents/download/62782.

Amuron B, Levin J, Birunghi J, Namar G, Coutinho A, Grosskurth H, and Shabbar J. (2011). Mortality in an antiretroviral therapy programme in Jinja, south-east Uganda: a prospective cohort study. AIDS Research and Therapy, 8(1), pp.39. 
Anastasi E, Borchert M, Campbell O M, Sondorp E, Kaducu F, and Hill Lange I. L. (2015). Losing women along the path to safe motherhood: why is there such a gap between women's use of antenatal care and skilled birth attendance? A mixed methods study in northern Uganda. BMC Pregnancy and Childbirth, 15(1), pp.287.

Anderson k, Basalirwa R, Mwesigwa H J.W.B, Okorio J, and Sserunkuma D. (2006).

Africare/Uganda: Uganda food security initiative -- phase 2: final evaluation report.

Washington D.C: USAID, pp.134. Available at:

https://pdf.usaid.gov/pdf_docs/PDACG740.pdf.

Anderson T. (2018). MyChild Solution in Uganda: An External Evaluation -Transfer of Work Processes to Existing Health. Tallinn: Tallinn University, pp.23. Available at: https://shifo.org/doc/rmnch/ShifoExternalEvaluationTransferProcessUganda.pdf.

Ankomah A, Spicehandler J, Kibuuka F, and Mobley S. (2013). USAID/Uganda AFFORD: health marketing initiative project evaluation: improving the lives of Ugandans. Washington D.C: USAID, pp.98. Available at: https://pdf.usaid.gov/pdf_docs/PA00JJRR.pdf.

Anyanwu J C, and Erhijakpor A E.O. (2009). Health Expenditures and Health Outcomes in Africa. African Development Review, 21(2), pp.400-433.

Arati B. (2006). Implementation completion report for Uganda - Lake Victoria Environmental Management Project. Washington D.C: World Bank, pp.59. Available at: http://documents.worldbank.org/curated/en/287101468121509023/Uganda-LakeVictoria-Environmental-Management-Project.

Arensberg W. (2007). Uganda: Bwindi Impenetrable National Park and Mgahinga Gorilla National Park Conservation Project (PPAR). Washington D.C: World Bank, pp.47. Available at: http://www.oecd.org/derec/worldbankgroup/39618444.pdf.

Arensberg W. (2007). Project performance assessment report for Uganda - Bwindi Impenetrable National Park and Mgahinga Gorilla National Park Conservation Project. Washington D.C: World Bank, pp.44. Available at: http://documents.worldbank.org/curated/en/208211468176928861/Uganda-BwindiImpenetrable-National-Park-and-Mgahinga-Gorilla-National-Park-ConservationProject.

Asadullah A, McIntyre N, and Kigobe M A. X. (2008). Evaluation of five satellite products for estimation of rainfall over Uganda / Evaluation de cinq produits satellitaires pour l'estimation des précipitations en Ouganda. Hydrological Sciences Journal, 53(6), pp.1137-1150.

Asebe E, and Martinez R. (2000). Uganda - First Urban Project. Washington D.C: World Bank, pp.55. Available at:

http://documents1.worldbank.org/curated/en/844241468317660632/pdf/multiOpage. pdf.

Ashburn K, Kerner B, Ojamuge D, and Lundgren R. (2017). Evaluation of the Responsible, Engaged, and Loving (REAL) Fathers Initiative on Physical Child Punishment and Intimate Partner Violence in Northern Uganda. Prevention Science, 18(7), pp.854-864. 
Asiimwe J B, Bagyendera J, Balyeku A, Emmet W, Namudda J, and Kalangwa A. (2015). Evauation of USAID/Ugandas district-based technical assistance (DBTA) model as applied under Strengthening Tuberculosis and HIV/AIDS Responses (STAR) projects in east east-central and south-west Uganda. Washington D.C: USAID, pp.56. Available at: https://www.usaid.gov/sites/default/files/documents/1860/Attachment\%20NSTARS\%20Merged\%20Report.pdf.

Asingwire N, Muhangi D, Asiimwe J B, Kyomuhendo S, and Buyungo P. (2016). Process Evaluation of GOU Uganda Family Planning Programs and Policies to Design Robust Impact Evaluations: Increasing Demand through Male Involvement and Promotion among Young People: Office of the Prime Minister.

Atuyambe L M, Kibira S P.S, Bukenya J, Muhumuza C, Apolot R R, and Mulogo E. (2015). Understanding sexual and reproductive health needs of adolescents: evidence from a formative evaluation in Wakiso district, Uganda. Reproductive health, 12(1), pp.35.

Austrian K. (2011). Safe and smart savings products for vulnerable adolescent girls in Kenya and Uganda: Results from the Uganda pilot evaluation. Kampala: Population council, pp.20. Available at: https://knowledgecommons.popcouncil.org/departments_sbsrpgy/6/.

Averch C E, and Harlow M. (2007). Evaluation of DCA guarantee programs \& impact: 20022007 -- final report. Washington D.C: USAID, pp.74. Available at: https://pdf.usaid.gov/pdf_docs/PDACK985.pdf.

Awor P, Wamani H, Tylleskar T, Jagoe G, and Peterson S. (2014). Increased Access to Care and Appropriateness of Treatment at Private Sector Drug Shops with Integrated Management of Malaria, Pneumonia and Diarrhoea: A Quasi-Experimental Study in Uganda. PLOS ONE, 9(12), pp.e115440.

Ayiasi R M, Kolsteren P, Batwala V, Criel B, and Garimoi O C. (2016). Effect of Village Health Team Home Visits and Mobile Phone Consultations on Maternal and Newborn Care Practices in Masindi and Kiryandongo, Uganda: A Community-Intervention Trial. PLOS One, 11(4), pp.e0153051.

Ayiasi R M, Muhumuza C, Bukenya J, and Garimoi O C. (2015). The effect of prenatal counselling on postpartum family planning use among early postpartum women in Masindi and Kiryandongo districts, Uganda. Pan African Medical Journal, 21(1), pp.138.

Azuba R, Zziwa A S, Muhumuza J, and Vittum K. (2018). Evaluation: supporting access to justice, fostering peace and equity (SAFE) program. Washington D.C: USAID, pp.82. Available at: https://pdf.usaid.gov/pdf_docs/PA00TDP4.pdf.

Babel M S, and Turyatunga E. (2014). Evaluation of climate change impacts and adaptation measures for maize cultivation in the western Uganda agro-ecological zone.

Theoretical and applied climatology, 119(1-2), pp.239-254.

Bagyendera J K, Nshakira N, Mwesigwa J M, Nahabwe P, and Gumisiriza D. (2014). The Evaluation Report for The Joint UN Programme of Support on AIDS in Uganda (JUPSA 
2011-2014). New York: United Nations Development Programme, pp.108. Available at: https://erc.undp.org/evaluation/documents/detail/8713.

Bagyendera J K, Ssemakula H M, Arinaitwe J, and Mwesigw J.M. (2018). United Nations development assistance framework (UNDAF) 2016-2020 for Uganda: Mid-term evaluation. New York: UNDP, pp.79. Available at: https://erc.undp.org/evaluation/evaluations/detail/9774\#.

Balikowa D. (2011). A Review of Uganda's Dairy Industry. Kampala: Dairy Development Authority, pp.89. Available at: http://www.fao.org/3/a-aq292e.pdf.

Bandiera O, Buehren N, Burgess R, Goldstein M, Gulesci M, Rasul I, and Munshi. (2017). Women's Empowerment in Action: Evidence from a Randomized Control Trial in Africa. Washington D.C: World Bank, pp.43. Available at: https://www.povertyactionlab.org/sites/default/files/research-paper/WomensEmpowerment-in-Action_Bandeiera-et-al.July2017.pdf.

Bangirana P, Allebeck P, Boivin M, Chandy J, Page C, Ehnvall A, and Musisi S. (2011). Cognition, behaviour and academic skills after cognitive rehabilitation in Ugandan children surviving severe malaria: A randomised trial. BMC neurology, 11(1), pp.96.

Bangirana P, Allebeck P, and Boivin MJ. (2011). Cognition, Behaviour and Academic Skills After Cognitive Rehabilitation in Ugandan Children Surviving Severe Malaria: A Randomised Trial. BMC Neurol. 2011, and 11:96.

Bangirana P, Giordani B, Chandy C J, Page C, Opoka R O, and Boivin M J. (2009). Immediate Neuropsychological and Behavioral Benefits of Computerized Cognitive Rehabilitation in Ugandan Pediatric Cerebral Malaria Survivors. Journal of Developmental \&, and Behavioral Pediatrics, 30(4), pp.310-318.

Baptiste R J, Siobhan G, Malik J, and Hamba Y. (2016). Monitoring and evaluation of emergency plan progress II (MEEPP II) performance evaluation. Washington D.C: USAID, pp.181. Available at: https://pdf.usaid.gov/pdf_docs/PBAAF059.pdf.

Bardfield L, Lugalambi G, Pratt B A, and Augustine W. (2018). Evaluating USAID/Uganda'S social and behaviour change communication activity: evidence-based learnings and strategic recommendations. Washington D.C: USAID, pp.121. Available at: https://pdf.usaid.gov/pdf_docs/PA00TDP5.pdf.

Barigye $H$, Levin J, Maher D, Tindiwegi G, Atuhumuza E, Nakibinge S, and Grosskurth H. (2010). Operational evaluation of a service for prevention of mother-to-child transmission of HIV in rural Uganda: barriers to uptake of single-dose nevirapine and the role of birth reporting. Tropical Medicine \& International Health, 15(10), pp.11631171.

Barofsky J, Anekwe T D, and Chase C. (2015). Malaria eradication and economic outcomes in sub-Saharan Africa: Evidence from Uganda. Journal of Health Economics, 44, pp.118136.

Barr A, Bategeka L, Guloba M, Kasirye I, Mugisha F, and Serneels P. (2012). Management and Motivation in Ugandan Primary Schools: An impact evaluation report. England: 
Partnership for Economic Policy, pp.42. Available at: https://portal.pepnet.org/documents/download/id/20172.

Barron P, Balyeku A, Kebba A, Lalobo C, and Nankinga J. (2007). Final evaluation of UPHOLD, [Uganda] program for human and holistic development (UPHOLD). Washington D.C: USAID, pp.71. Available at: https://pdf.usaid.gov/pdf_docs/PDACL386.pdf.

Baryomunsi C, Mbonye A, Oguttu J, and Nakato L. (2002). Community Reproductive Health Project (CREHP II) Final Evaluation Report. Geneva: CARE, pp.27. Available at: https://www.careevaluations.org/evaluation/crehp-final-evaluation-report/.

Bass J, Neugebauer R, Clougherty K F, Verdeli H, Wickramaratne P, Ndogoni L, Speelman L, Weissman M, and Bolton P. (2006). Group interpersonal psychotherapy for depression in rural Uganda: 6-month outcomes: Randomised controlled trial. British Journal of Psychiatry, 188(6), pp.567-573.

Beemer H L. (2015). Implementation Completion and Results Report for A Uganda-Post Primary Education and Training. Washington D.C: World Bank, pp.97. Available at: http://documents.worldbank.org/curated/en/462481468306254644/Uganda-PostPrimary-Education-and-Training-Adaptable-Program-Lending-Project.

Beltramo T, Blalock G, Levine D, and Simons A. (2015). The effect of marketing messages and payment over time on willingness to pay for fuel-efficient cookstoves. Journal of Economic Behavior \& Organization, 118, pp.333-345.

Benavente J, Gidudu H E, Nshakira N, Ramadhan H, and Tapera J. (2009). End-of-project evaluation of the ACE program: final evaluation report. Washington D.C: USAID, pp.103. Available at: https://pdf.usaid.gov/pdf_docs/PDACP438.pdf.

Bendavid E, Holmes C, Bhattacharya J, and Miller G. (2012). HIV development assistance and adult mortality in Africa. JAMA, 307(19), pp.2060-2067.

Bender P A. (2002). Implementation completion report for Uganda - Primary Education and Teacher Development Project. Washington D.C: World Bank, pp.71. Available at: http://documents1.worldbank.org/curated/en/349991468110948689/pdf/multiOpage. pdf.

Benin S, Nkonya E, Okecho G, Pender J, Nahdy S, and Mugarura S. (2007). Assessing the impact of the National Agricultural Advisory Services (NAADS) in the Uganda rural livelihoods. Washington D.C: International Food Policy Research Institute, pp.92. Available at: http://www.ifpri.org/publication/assessing-impact-national-agriculturaladvisory-services-naads-uganda-rural-livelihoods.

Benin S, Nkonya E, Okecho G, and Randriamamon J. (2012). Impact of the National Agricultural Advisory Services (Naads) program of Uganda: Considering Different Levels of Likely Contamination with the Treatment. American Journal of Agricultural Economics, 94(2), pp.386-392.

Benin S, Nkonya E, Okecho G, Randriamamonjy J, Kato E, Lubade G, and Kyotalimye M. (2011). Returns to spending on agricultural extension: the case of the National 
Agricultural Advisory Services (NAADS) program of Ugandat. Agricultural Economics, 42(2), pp.249-267.

Berry J, Wood J, Odaet K, and Balemesa T. (2003). Local Solutions to Global Challenges:

Towards Effective Partnership in Basic Education - Uganda. Amsterdam: Netherlands Ministry of Foreign Affairs, pp.134. Available at:

http://www.oecd.org/countries/uganda/35148753.pdf.

Betancourt T S, Newnham E A, Brennan R T, Verdeli H, Borisova I, Neugebauer R, Bass J, and Bolton P. (2012). Moderators of Treatment Effectiveness for War-Affected Youth with Depression in Northern Uganda. Journal of Adolescent Health, 51(6), pp.544-550.

Betubiza E. (2014). Implementation Completion and Results Report for The Uganda-Avian and Human Influenza Preparedness and Response Project. Washington D.C: World Bank, pp.46. Available at:

http://documents1.worldbank.org/curated/en/706761468308686255/pdf/ICR31440P1 10200IC0disclosed07010140.pdf.

Betubiza E, and Lufafa A. (2014). Final Evaluation of the Avian and Human Influenza Preparedness and Response Project (AHIP). Washington D.C: World Bank, pp.46. Available at:

http://documents.worldbank.org/curated/en/660961475114036848/UgandaPreparedness-And-Control-Of-Avian-Influenza.

Bigira V, Kapisi J, Clark T D, Kinara S, Mwangwa F, Muhindo M K, Osterbauer B, Aweeka F T, Huang L, Achan J, Havlir D V, Rosenthal P J, Kamya M R, and Dorsey G. (2014).

Protective Efficacy and Safety of Three Antimalarial Regimens for the Prevention of Malaria in Young Ugandan Children: A Randomized Controlled Trial. PLoS Medicine, 11(8), pp.e1001689.

Birungi N, Fadnes L T, Okullo I, Kasangaki A, Nankabirwa V, Ndeezi G, Tumwine J K, Tylleskar T, Lie S A, and Nordrehaug A A. (2015). Effect of breastfeeding promotion on early childhood caries and breastfeeding duration among 5 year old children in Eastern Uganda: a cluster randomized trial. PLoS ONE, 10(5), pp.e0125352.

Björkman M. (2007). Does Money Matter for Student Performance? Evidence from a Grant Program in Uganda. Development economics, pp.41.

Björkman M, and Svensson J. (2010). When is Community-Based Monitoring Effective? Evidence from a Randomized Experiment in Primary Health in Uganda. Journal of European Economic Association, 8(2-3), pp.571-581.

Björkman M, and Svensson J. (2009). Power to the People: Evidence from a Randomized Field Experiment on Community-Based Monitoring in Uganda*. The Quarterly Journal of Economics, 124(2), pp.735-769.

Bjorkman N M, Svensson J, and Yanagizawa D D. (2012). Can Good Products Drive Out Bad? Evidence from Local Markets for (Fake?) Antimalarial Medicine in Uganda. Center for International Development Working Paper 242, pp.242. 
Bjorn V C. (2016). Is There an App for That? The Impact of Community Knowledge Workers in Uganda. Information, and Communication \& Society, 20(4), pp.530-550.

Blattman C, Fiala N, and Martinez S. (2012). Employment Generation in Rural Africa: MidTerm Results from an Experimental Evaluation of the Youth Opportunities Program in Northern Uganda. Washington D.C: World Bank, pp.76. Available at: http://www.diw.de/documents/publikationen/73/diw_01.c.395796.de/dp1201.pdf.

Blattman C, Fiala N, and Martinez S. (2013). Generating Skilled Self-Employment in Developing Countries: Experimental Evidence from Uganda. The Quarterly Journal of Economics, 129 (2), pp.697-752.

Blattman C, Green E P, Jamison J, and Annan J. (2015). Women's entrepreneurship and intimate partner violence: A cluster randomized trial of microenterprise assistance and partner participation in post-conflict Uganda. Social Science \& Medicine, 33, pp.177188.

Blattman C, Jamison J, Green E P, and Annan J. (2016). The Returns to Microenterprise Support Among the Ultra-Poor: A Field Experiment in Post-War Uganda. American Economic Journal: Applied Economics, 8(2), pp.35-64.

Blue R, Wandera A, Balyaku A, Turinde A, Okot C R, Walusimbi R, and Kamukama R. (2007). AIM project evaluation: final report. Washington: USAID, pp.135. Available at: https://pdf.usaid.gov/pdf_docs/PDACL388.pdf.

Bogetic Z, Caputo E, and Valmarana C. (2015). JOINT EVALUATION OF BUDGET SUPPORT TO UGANDA. Washington D.C: World Bank, pp.101. Available at:

https://www.researchgate.net/profile/Zeljko_Bogetic/publication/302553148_Joint_Eval uation_of_Budget_Support_to_Uganda_2004-

13/links/57310ae908ae100ae5574d75/Joint-Evaluation-of-Budget-Support-to-Uganda2004-13.pdf?origin=publication_detail.

Bolton P, Bass J, Betancourt T, and et al. (2007). Interventions for depression symptoms among adolescent survivors of war and displacement in northern Uganda: $A$ randomized controlled trial. JAMA, 298(5), pp.519-527.

Bolton P, Bass J, and Neugebauer R. (2003). Group interpersonal psychotherapy for depression in rural Uganda: A randomized controlled trial. JAMA, 289(23), pp.31173124.

Borde A, and Natumanya E. (2017). Low Emission Capacity Building (LECB) Project for Uganda. New York: United Nations Development Program, pp.78. Available at: https://erc.undp.org/evaluation/documents/detail/10698.

Bradley A K.I. (2014). Supplemental Implementation Completion and Results Report for a Component E Under Privatization and Utility Sector Reform Project, Support to Umeme Limited. Washington D.C: World Bank, pp.55. Available at: http://documents.worldbank.org/curated/en/616481468113334496/UgandaComponent-E-Under-Privatization-and-Utility-Sector-Reform-Project. 
Buescher G S, and Anyuru M A. (2013). Final Evaluation of The Northern Uganda Early Recovery Project. New York: United Nations Development Programme, pp.110. Available at: https://erc.undp.org/evaluation/documents/detail/6965.

Bugnion C, Bigombe B, Musoke R A, and Vadivelu V. (2009). Assessment of Development Results: Evaluation of UNDP Contribution to Uganda. New York: UNDP, pp.121. Available at: http://www.oecd.org/countries/uganda/46820437.pdf.

Buwembo D R, Musoke R, Kigozi G, Ssempijja V, Serwadda D, Makumb F, Watya S, Namuguzi D, Nalugoda F, Kiwanuka n, Sewankambo N K, Wabwire M F, Kiggundu V, Wawer M J, and Gray R H. (2012). Evaluation of the safety and efficiency of the dorsal slit and sleeve methods of male circumcision provided by physicians and clinical officers in Rakai, Uganda. BJU InternationalBJU International, 109(1), pp.104-108.

Bwanga F, Joloba M L, Haile M, and Hoffner S. (2010). Evaluation of seven tests for the rapid detection of multidrug-resistant tuberculosis in Uganda. The International Journal of Tuberculosis and Lung Disease, 14(7), pp.890-895.

Bwanika G. (2017). Strengthening Disaster Reduction Management and Resilience Building Project. New York: United Nations Development Programme (UNDP), pp.73. Available at: https://erc.undp.org/evaluation/documents/detail/10584.

Bweibo A, Lander R, and Neha K. (2010). Breaking barriers project: Kenya, Uganda and Zambia: end-term evaluation report. Washington D.C: USAID, pp.73. Available at: https://pdf.usaid.gov/pdf_docs/PDACR832.pdf.

Byamugisha R, Astrøm A N, Ndeezi G, Karamagi C A.S, Thorkild T, and Tumwine J. (2011). Male partner antenatal attendance and HIV testing in eastern Uganda: A randomized facility-based intervention trial.

Caceres S A. (2016). Project Performance Assessment Report for Uganda Millennium Science Initiative. Washington D.C: World bank, pp.46. Available at: http://documents1.worldbank.org/curated/en/812191467995625310/pdf/102970REPLACEMENT-SAME-BOX-PUBLIC-SecM2016-0135.pdf.

Cachan J, Lillian O U, and Spindler E. (2018). WALAN pilot: final evaluation report: assessing the effectiveness of a group counseling model for couples on fertility awareness method (FAM) in Northern Uganda. Washington D.C: USAID, pp.91. Available at: https://pdf.usaid.gov/pdf_docs/PA00T89X.pdf.

Cadena X, and Schoar A. (2011). Remembering to Pay? Reminders vs. Financial Incentives for Loan Payments. National Bureau of Economic Research Working Paper Series, No. 17020 , pp.30.

Canagarajah S, and Diesen A V. (2011). The Poverty Reduction Strategy Approach Six Years On: An Examination of Principles and Practice in Uganda. Oxford: Blackwell, pp.35-56. Available at: https://onlinelibrary.wiley.com/doi/pdf/10.1111/j.14677679.2006.00352.x. 
CARE. (2002). Final Project Implementation Report; Food Production Enhancement (FOPE) Project. Geneva: CARE, pp.15. Available at: https://www.careevaluations.org/evaluation/fope-end-report-final-02-02/.

Care International. (2017). Project for Financial Inclusion in Rural Areas (PROFIRA) Baseline Report. Genenva: CARE, pp.88. Available at:

https://www.careevaluations.org/evaluation/project-for-financial-inclusion-in-ruralareas-profira-baseline-report/.

Care International. (2014). Forest Resources Sector Transparency Programme (Forest) Revised Baseline Report. Geneva: CARE, pp.57. Available at: https://sevaluation/forestprogramme-baseline/.

Care International. (2014). Women Empowerment Program (WEP) 2009-2013, Final Report. Geneva: CARE, pp.55. Available at:

https://www.careevaluations.org/evaluation/womens-empowerment-program-wep2009-2013/.

Care International. (2006). Strengthening and Empowering Civil Society for participatory Forest Management in East Africa (EMPAFORM) Baseline Survey Report. Geneva: CARE, pp.54. Available at: https://www.careevaluations.org/evaluation/uga-empaformmasindi-baseline-jan-06/.

Carl Bro International. (2001). Evaluation report of a potable water project in Luwero district. OSLO: NORAD: NORAD, pp.43. Available at: https://norad.no/en/toolspublications/publications/ngo-evaluations/2009/evaluationreport-of-a-potable-water-project-in-luwero-district/.

Carlton A, Manndorff H, Obara A, and Reiter W. (2001). Microfinance in Uganda. Vienna: Austrian Ministry of Foreign Affairs, Department for Development Cooperation, pp.78. Available at: http://www.oecd.org/countries/uganda/35481055.pdf.

Carroll R, and Karen H. (2010). Implementation Completion and Results Report for Uganda Fifth, Sixth, And Seventh Poverty Reduction Support Credit Project. Washington D.C: World Bank, pp.80. Available at:

http://documents1.worldbank.org/curated/en/534731468316985904/pdf/ICR11210P0 90881C0disclosed071221101.pdf.

Carter R. (2006). Volume II - Stakeholder Perceptions - Evaluation of Danish Aid to Uganda 1987-2005. Copenhagen: Ministry of Foreign Affairs, Denmark, pp.106. Available at: http://www.oecd.org/countries/uganda/37894940.pdf.

Castro R. (2001). Implementation completion report for Uganda - Environmental Management and Capacity Building Project. Washington D.C: World Bank, pp.31. Available at: http://documents1.worldbank.org/curated/en/331461468177544451/pdf/multiOpage. pdf. 
Chamie G, Kwarisiima D, Clark T D, Kabami J, Jain V, Geng E, and Charlebois E D. (2012). Leveraging Rapid Community-Based HIV Testing Campaigns for Non-Communicable Diseases in Rural Uganda. PloS one, 7(8), pp.e43400.

Chang K H, Ssewamala F M, and Wang J S.H. (2013). Family economic empowerment and mental health among AIDS-affected children living in AIDS-impacted communities: evidence from a randomised evaluation in southwestern Uganda. Journal of Epidemiology and Community Health, 67(3), pp.225-230.

Chang L W, Alamo S, Guma S, Christopher J, Suntoke T, Omasete R, Montis J P, Quinn T C, Juncker M, and Reynolds S J. (2009). Two Year Virologic Outcomes of an Alternative AIDS Care Model: Evaluation of a Peer Health Worker and Nurse-Staffed CommunityBased Program in Uganda. AIDS, 50(3), pp.276-282.

Chang L W, Kagaayi J, Arem H, Nakigozi G, Ssempijja V, Serwadda D, Quinn T C, Gray R.H, Bollinger R C, and Reynolds S J. (2011). Impact of a mHealth Intervention for Peer Health Workers on AIDS Care in Rural Uganda: A Mixed Methods Evaluation of a Cluster-Randomized Trial. AIDS and Behavior, 15(8), pp.1776-1784.

Chang L W, Kagaayi J, Nakigozi G, Ssempijja V, Packer A H, Serwadda D, Quinn T C, Gray R H, Bollinger R C, and Reynolds S J. (2010). Effect of Peer Health Workers on AIDS Care in Rakai, Uganda: A Cluster-Randomized Trial. PLOS ONE, 5(6), pp.e10923.

Chang L W, Kaye D, Muhwezi W W, Nabirye R C, Mbalinda S, Okullo I, and Burnham G. (2011). Perceptions and valuation of a community-based education and service (COBES) program in Uganda. Medical Teacher, 33(1), pp.9-15.

Chang L W, Nakigozi G, Billioux V G, Gray R H, Serwadda D, Quinn T C, Wawer M J, Bollinger R C, and Reynolds S J. (2015). Effectiveness of peer support on care engagement and preventive care intervention utilization among pre-antiretroviral therapy, HIV-infected adults in Rakai, Uganda: A randomized trial. AIDS and Behavior, 19(10), pp.1742-1751.

Chapman N, Vaillant C, Kabuchu H, Muhwana W, and Adupa L. (2008). Evaluation of the Irish Aid Uganda Country Strategy Paper 2007-2009. Ireland: Irish Aid, pp.142. Available at: http://www.oecd.org/countries/uganda/46924709.pdf.

Charo R K, Rianarisata J, Yol A, Ekoh P O, Oswarld L, and Odera W O. (2011). Multinational Multinational African Virtual University Support Project - Project Completion Report (PCR). Abidjan: African Development Bank, pp.38. Available at: https://www.afdb.org/fileadmin/uploads/afdb/Documents/Project-andOperations/Multinational__African_virtual_university_support_project_phase_II_AVU_II_.pdf.

Chenais E, Sternberg L S, Boqvist S, Emanuelson U, Aliro T, Tejler E, and Ståhl K. (2015). African swine fever in Uganda: qualitative evaluation of three surveillance methods with implications for other resource-poor settings. Frontiers in Veterinary Science, 2, pp.51. 
Chikoore C, and Opolot S. (2013). Mid Term Evaluation - UN Joint Programme on Gender Equality (UNJPGE) - Uganda. New York: United Nations Development Programme (UNDP), pp.69. Available at: https://erc.undp.org/evaluation/documents/detail/8249.

Chisvo M, Conrad C, Ofwono C, Baliddawa J, and Ngonidzaishe M. (2015). Review of the Uganda country strategy 2010-2015. Vienna: Austrian Development Agency (ADA), pp.99. Available at: http://www.oecd.org/derec/austria/Review-Evaluation-Uganda2010-2015.pdf.

Chisvo M, and Ofwono N. (2008). Evaluation of the Implementation of the Paris Declaration in Uganda. Kampala: Office of the Prime Minister, pp.121. Available at: https://www.oecd.org/countries/uganda/47722353.pdf.

Chisvo M, and Ofwono N. (2008). Evaluation of the Implementation of the Paris Declaration in Uganda. Kampala: Office of the Prime Minister, Government of the Republic of Uganda, pp.121. Available at: https://www.oecd.org/countries/uganda/47722353.pdf.

Chiwara R M, Kalibwani R J, Kazoora C, and Kwamya W. (2008). Midterm Outcome Evaluation of The UNDP Poverty Reduction Programme 2006-2007. New York: United Nations Development Programme, pp.80. Available at: https://erc.undp.org/evaluation/documents/detail/1972.

Chong C K, Cho P Y, Na B K, Ahn S K, Kim J S, Lee J S, and ... Kim T. S. (2014). Evaluation of the Accuracy of the EasyTest ${ }^{\mathrm{TM}}$ Malaria Pf/Pan Ag, a Rapid Diagnostic Test, in Uganda. The Korean journal of parasitology, 52(5), pp.501-505.

Chowa G, and Ansong D. (2010). Youth and savings in Assets Africa. Children and Youth Services Review, 32(11), pp.1591-1596.

Chowa G A.N, and Elliott W. (2011). An asset approach to increasing perceived household economic stability among families in Uganda. The Journal of Socio-Economics, 40(1), pp.81-87.

Chowdhury M, Sarker A, and Sahlen K. (2018). Evaluating the data quality, efficiency and operational cost of MyChild Solution in Uganda: Kampala: UMEA University, pp.30. Available at: https://shifo.org/doc/rmnch/MyChildExternalEvaluationUganda2018.pdf.

Chyi Y H. (2014). Implementation Completion and Results Report for A Kampala Institutional and Infrastructure Development. Washington D.C: World Bank, pp.92. Available at: http://documents.worldbank.org/curated/en/545191468349818537/Uganda-AKampala-Institutional-and-Infrastructure-Development-Adaptable-Program-Loan-APLProject.

Ciccio L, Makumbi M, and Sera D. (2010). An evaluation study on the relevance and effectiveness of training activities in Northern Uganda. Rural Remote Health, 10(1), pp.1250.

Cilliers J, Kasirye I, Leaver C, Serneels P, and Zeitlin A. (2018). Pay for locally monitored performance? A welfare analysis for teacher. Journal of public economics, 167, pp.6990. 
Clark S, Khan M E, Sussman L, and White A. (2018). Performance (endline) evaluation of the advancing partners and communities. Washington D.C: USAID, pp.126. Available at: https://pdf.usaid.gov/pdf_docs/PA00TCN9.pdf.

Claussen J, Basil K, and Pål J. (2005). Evaluation of the community-based rehabilitation programme in Uganda. Oslo: Norad: Oslo, Stockholm: Norwegian Association of the Disabled, pp.51. Available at: https://norad.no/globalassets/import-2162015-80434am/www.norad.no-ny/filarkiv/ngo-evaluations/evaluation-of-the-community-basedrehabilitation-program-in-uganda.pdf.

Cohen J, Fink G, Maloney K, Berg K, Jordan M, Svoronos T, Aberf F, and Dickens W. (2015). Introducing rapid diagnostic tests for malaria to drug shops in Uganda: a clusterrandomized controlled trial. Bulletin of the World Health Organization, 93 (3), pp.142151.

Coleman E A, and Fleischman F D. (2012). Comparing Forest Decentralization and Local Institutional Change in Bolivia, Kenya, Mexico, and Uganda. World Development, 40(4), pp.836-849.

Conroy KJ, Moehler D C, and Aguilar R. (2015). Partisan Cues and Vote Choice in New Multiparty Systems. SAGE Journals, 49(1), pp.3-35.

Consultant Architect, a Consultant Health Planner, and OCDE 3. (2001). Uganda - Second Health Services Rehabilitation Project - Completion Report. Abidjan: African Development Bank, pp.37. Available at: https://www.afdb.org/fileadmin/uploads/afdb/Documents/Project-andOperations/ADF-BD-IF-2001-23-EN-COMPLET-UGANDA-PCR.PDF.

Cotton L. (2006). Implementation completion and results report for Uganda - Privatization and Utility Sector Reform Project. Washington D.C: World Bank, pp.51. Available at: http://documents.worldbank.org/curated/en/421401468310743518/UgandaPrivatization-and-Utility-Sector-Reform-Project.

Craig M. (2008). Estimating Treatment Effects from Spatial Policy Experiments: An Application to Ugandan Microfinance. The Review of Economics and Statistics, 90(1), pp.15-28.

Crousillat E, and Usui K. (2018). Uganda - Private Power Generation (Bujagali) Project. Washington D.C: World Bank, pp.57. Available at: http://documents1.worldbank.org/curated/en/546131539715898602/pdf/Bujagali-ICRReport-10102018.pdf.

Crousillat E, and Usui K. (2018). Implementation completion and results report private power generation (Bujagali) project. Washington D.C: World Bank, pp.57. Available at: http://documents.worldbank.org/curated/en/546131539715898602/pdf/Bujagali-ICRReport-10102018.pdf.

DART trial team. (2010). Routine versus clinically driven laboratory monitoring of HIV antiretroviral therapy in Africa (DART): a randomised non-inferiority trial. The Lancet, 375(9709), pp.123-131. 
Datta M J. (2001). Uganda - Country assistance evaluation: Uganda stakeholder voices: perceptions of the World Bank's country assistance strategy (Vol. 2). Washington D.C: World Bank, pp.232.

Davis K, Nkonya E, Kato E, Mekonnen D A, Odendo M, Miiro R, and Nkuba J. (2012). Impact of Farmer Field Schools on Agricultural Productivity and Poverty in East Africa. World Development, 40(2), pp.402-413.

De Kemp A, and Eilor J. (2008). Primary Education in Uganda. Amsterdam: Policy and Evaluations Operations Department (IOB), pp.212. Available at: http://www.oecd.org/countries/uganda/41464402.pdf.

De Nooijer P G. (2013). The Netherlands and the European Development Fund - Principles and Practices: Evaluation of Dutch involvement in EU development cooperation (19982012). Amsterdam: IOB, pp.312. Available at: http://www.oecd.org/derec/netherlands/NETHERLANDSandtheEDFDutchlnvolvementi nEUDevCoop.pdf.

Deininger K, and Mpuga P. (2004). Does Greater Accountability Improve the Quality of Delivery of Public Services? Evidence from Uganda. World development, (3277), pp.21.

De-Kemp A, Eilor J, and Ochieng E O. (2008). IOB - Impact evaluation. Primary education in Uganda. Amsterdam: Government of Netherlands, pp.212. Available at: https://www.government.nl/documents/reports/2008/04/26/iob-impact-evaluationprimary-education-in-uganda.

Devfin Advisers. (2010). Evaluation of Norwegian Business-related Assistance - Uganda Case Study. Oslo: Norad: Norad, pp.148. Available at: http://www.oecd.org/derec/norway/45899970.pdf.

Devries K M, Knight L, Child J C, Mirembe A, Nakuti J, Jones R, Sturgess J, Allen E, Kyegombe N, Parkes J, Walakira E, Elbourne D, Watts C, and Naker D. (2015). The Good School Toolkit for reducing physical violence from school staff to primary school students: a cluster-randomised controlled trial in Uganda. Lancet Global Health, 3 (7), pp. e378386.

DeVries M D, and Olupot P O. (2005). Catholic Relief Services/Uganda: development assistance program (DAP) -- final evaluation report. Washington D.C: USAID, pp.52. Available at: https://pdf.usaid.gov/pdf_docs/PDACG739.pdf.

Disamis Srl. (2015). CinemArena:Itinerant program in health education in disadvantaged areas. Amsterdam: Ministry of Foriegn Affairs, Directorate General for Development coorporation, pp.86. Available at: http://www.oecd.org/derec/italy/CinemArena-KenyaUganda.pdf.

Dizon R R, Dupas P, and Robinson J. (2017). Governance and Effectiveness of Public Health Subsidies: Evidence from Ghana, Kenya and Uganda. J Public Econ, 156, pp.150-169.

Doll K, Bunkers K, Cobo A, Miller C, Andrews S, Walakira E, Bukenya B, and Ddumba I. (2015). Strengthening Uganda's national response for implementation of services for 
orphans and other vulnerable children: final evaluation. Washington D.C: USAID, pp.125. Available at: https://pdf.usaid.gov/pdf_docs/PA00KSGR.pdf.

Doll K, Bunkers K, Cobo A, Miller C, Andrews S, Walakira E, Bukenya B, and Ddumba I. (2015). Strengthening Uganda's National Response for Implementation of Services for Orphans and Other Vulnerable Children: Final Evaluation. Washington D.C: USAID, pp.125. Available at:

https://www.google.com/url?sa=t\&rct=j\&q=\&esrc=s\&source=web\&cd=1\&cad=rja\&uact =8\&ved=2ahUKEwjAOPuSvIfmAhXWXhUIHQjHDg4QFjAAegQIBRAC\&url=http\%3A\%2F\% 2Fwww.socialserviceworkforce.org\%2Fsystem\%2Ffiles\%2Fresource\%2Ffiles\%2FStrengt hening\%2520Uganda\%2527s\%2520National\%2520Response.pdf\&usg=AOvVaw1Og3Y 9xw0W48E-nBEZfcNC.

Downing J, Batuli M, Kivumbi G, Kabahweza J, Grant L, Murray S A, and Leng M. (2016). A palliative care link nurse programme in Mulago Hospital, Uganda: an evaluation using mixed methods. BMC Palliative Care, 15(1), pp.40.

Downing J, and Kawuma E. (2013). The impact of a modular HIV/AIDS palliative care education programme in rural Uganda. International Journal of Palliative Nursing, 14(11), pp.560-8.

Duggleby T, Kapoor R, Lai C, Midling M J, and Opolot M. (2015). Evaluation youthmap Uganda: final report. Washington D.C: USAID, pp.90. Available at: https://pdf.usaid.gov/pdf_docs/PA00TCT9.pdf.

Eidhammer A. (2011). Results of development cooperation through Norwegian NGOs in East Africa - Volume 1. Oslo: Norad: Norad, pp.179. Available at: http://www.oecd.org/countries/tanzania/48484978.pdf.

Ejuu G. (2012). The status of implementation of the education sector early childhood development policy in Uganda. Kampala: Uganda National Commission for UNESCO, pp.41. Available at: https://www.yumpu.com/en/document/view/47894782/status-ofimplementation-of-the-ecd-policy-in-uganda-ministry-of- .

Ekirapa K E, Waiswa P, Hafizur R M, Makumbi F, Kiwanuka N, Okui O, Rutebemberwa E, Bua J, Mutebi A, Nalwadda G, Serwadda D, Pariyo G W, and Peters D H. (2011). Increasing access to institutional deliveries using demand and supply side incentives: early results from a quasi-experimental study. BMC International Health and Human Rights, 11(1), pp.S11.

Euzobia M, and Mugisha B. (2013). A Terminal Evaluation for The Project "Gender Budget for Northern Uganda, Recovery, Reconstruction and Development". New York: United Nations Development Programme, pp.54.

Evaluation department, and Ministry of foreign affairs of Denmark. (2019). Evaluation of water, sanitation and environment programmes in Uganda (1990-2017). Copenhagen: Ministry of foreign affairs of Denmark, pp.98. Available at: http://www.netpublikationer.dk/UM/uganda_vandevaluering_feb2019/Pdf/uganda_va ndevaluering_feb2019.pdf. 
Evaluation Department, and Ministry of Foreign Affairs of Denmark. (2014). Joint Evaluation of Support to the National Response to HIV/AIDS in Uganda 2007-2012. Copenhagen: Ministry of Foreign Affairs of Denmark, pp.108. Available at:

http://www.oecd.org/derec/denmark/Support-to-the-national-response-to-hiv-aids-inuganda.pdf.

Evers G. (2001). Uganda - Agricultural Research and Training Project. Washington D.C: World Bank, pp.51. Available at:

http://documents.worldbank.org/curated/en/196711468121505434/UgandaAgricultural-Research-and-Training-Project.

Fadnes L, Nankabirwa V, Engebretsen I, Sommerfelt H, Birungi N, Lombard C, Swanevelder S, Broeck J V.D, Tylleskär T, and Tumwine J. (2016). Effects of an exclusive breastfeeding intervention for six months on growth patterns of 4-5 year old children in Uganda: the cluster-randomised PROMISE EBF trial. BMC Public Health, 16(1), pp.555.

FAO, and CP. (2000). Agricultural Extension Project. Washington D.C: World Bank, pp.59. Available at:

http://documents1.worldbank.org/curated/en/420021468309309527/pdf/multipage.pdf.

FARST AFRICA. (2011). GOAL Uganda: scaling up innovative HIV/AIDS interventions through strong partnerships amongst conflict-affected populations of Pader (Agago) District, Northern Uganda, 2008-2011: end project evaluation report. Washington D.C: USAID, pp.91. Available at: https://pdf.usaid.gov/pdf_docs/PDACT379.pdf.

Faruq H, Katsushi I, and Takahiro S. (2013). Impact of Agricultural Extension on Crop Productivity, Poverty and Vulnerability: Evidence from Uganda. Kobe: Research Institute for Economics and Business Administration, Kobe University, pp.33. Available at: https://www.rieb.kobe-u.ac.jp/academic/ra/dp/English/DP2012-34.pdf.

Ferretti S. (2018). External Evaluation of IAS and ADRA's SMC/ Sida funded Humanitarian Programme in Northern Uganda. Stockholm: Swedish Mission Council, pp.62. Available at: https://www.alnap.org/system/files/content/resource/files/main/finalreport-smc-uganda-evaluation1.pdf.

Fink G, Dickens W T, Jordan M, and Cohen J L. (2013). Access to subsidized ACT and malaria treatment-evidence from the first year of the AMFm program in six districts in Uganda. Health Policy and Planning, 29(4), pp.517-527.

Fitzpatrick Associates. (2008). Evaluation of Traidlinks. Dublin: Irish Aid, pp.113. Available at: http://www.oecd.org/countries/uganda/Traidlinks\%20evaluation.pdf.

Fleming F, Fenwick A, Tukahebwa E, Lubanga R, Namwangye H, Zaramba S, and Kabatereine N. (2009). Process evaluation of schistosomiasis control in Uganda, 2003 to 2006: perceptions, attitudes and constraints of a national programme. Parasitology, 136(13), pp.1759-1769. 
Forster J. (2012). Consolidated Annual Report on Activities Implemented under the UN Joint Programme "Gender Equality" (UN JP On Gender Equality). New York: UNDP, pp.26. Available at: https://www.ilo.org/ievaldiscovery/\#a2d44y.

Freeman P. (2017). Implementation Completion and Results Report for Uganda-Transport Sector Development Project. Washington D.C: World Bank, pp.87. Available at: http://documents1.worldbank.org/curated/en/284931506968826934/pdf/cleared-ICRP092837-docx-09292017.pdf.

Freeman P. (2011). Tanzania - Second Integrated Roads and Central Transport Corridor and Uganda - First and Second Phase Road Development and Roads Sector Institutional Support Technical Assistance Projects. Washington D.C: World Bank, pp.139. Available at:

http://documents1.worldbank.org/curated/en/822071468311443100/pdf/624330PPAR OP040e0only0900BOX361497B.pdf.

Freeman P, Kwiyucwiny G, Nshakira N, Muhangi D, and Tapera J. (2010). End-of-project evaluation of the capacity project: final evaluation report. Washington D.C: USAID, pp.123. Available at: https://pdf.usaid.gov/pdf_docs/PDACR794.pdf.

Fuentes R, Pfuetze T, and Seck P. (2006). Does Access to Water and Sanitation Affect Child Survival? A Five Country Analysis. New York: UNDP, pp.440. Available at: http://hdr.undp.org/en/reports/global/hdr2006/papers/Fuentes\%20et\%20al\%20A.pdf.

Galiwango R M, Musoke R, Lubyayi L, Ssekubugu R, Kalibbala S, Ssekweyama V, and Kigozi G. (2013). Evaluation of current rapid HIV test algorithms in Rakai, Uganda. Journal of virologic methods, 192(1-2), pp.25-27.

Gapare N. (2018). UN-REDD Uganda National Programme Final Evaluation. New York: United Nations Development Programme, pp.101. Available at: https://erc.undp.org/evaluation/documents/download/11795.

Garcia J, and Sackey J. (2009). Project Performance Assessment Report for Uganda - First, Second, Third, And Fourth Poverty Reduction Support Credit Projects. Washington D.C: World Bank, pp.82. Available at: http://documents1.worldbank.org/curated/en/332711468175737633/pdf/489420PPAR 01 mu1010fficial0Use00nly1.pdf.

Gavi Full Country Evaluations Team. (2017). Uganda: Findings from the 2016 Gavi Full Country Evaluations. Geneva: Gavi, pp.53. Available at: http://www.healthdata.org/sites/default/files/files/policy_report/2017/GaviFCE_Uganda-Country-Report_2017.pdf.

Gayfer J, Barnes J, Jennings M, and Kayondo A. (2012). Formative evaluation of World Food Programme's Livelihoods Programme, Karamoja, Uganda. London: DFID, pp.92. Available at: http://www.oecd.org/derec/unitedkingdom/2_Evaluation\%20formativeWorld\%20Food \%20Programme\%20Livelihoods\%20Programme\%20in\%20Karamoja\%20Uganda.pdf. 
Gebremedhin D, and Isooba D. (2014). Uganda - Road Maintenance and Upgrading Project Project Completion Report (PCR). Abidjan: African Development Bank, pp.43. Available at: https://www.afdb.org/fileadmin/uploads/afdb/Documents/Evaluation-Reports_Shared-WithOPEV_/UGANDA\%20ROAD\%20MAINTENANCE\%20AND\%20UPGRADING\%20PROJECTPCR-17-02-2011.pdf.

Gelders B, and Athias D. (2019). Quantitative Impact Analysis of Uganda's Senior Citizens Grant. London: Development pathways, pp.57. Available at: https://www.developmentpathways.co.uk/wpcontent/uploads/2019/03/SCG_impact_final-2019-1.pdf.

Gilligan D O, Karachiwalla N, Kasirye I, Lucas A M, and Neal D. (2018). EDUCATOR INCENTIVES AND EDUCATIONAL TRIAGE IN RURAL PRIMARY. Journal of human resources, pp.40.

Gilligan D O, Kumar N, McNiven S, Meenakshi J V, and Quisumbing A. (2014). Bargaining Power and Biofortification - The Role of Gender in Adoption of Orange Sweet Potato in Uganda. Washington, D.C.: International Food Policy Reserach Institute , pp.28. Available at:

http://cdm15738.contentdm.oclc.org/utils/getfile/collection/p15738coll2/id/128184/file name/128395.pdf.

Gilligan D O, Margolies A, Quiñones E, and Shalini R. (2012). Impact Evaluation of Cash and Food Transfers at Early Childhood Development Centers in Karamoja, Uganda. Washington, D.C.: International Food Policy Research Institute, pp.121. Available at: http://www.ifpri.org/publication/impact-evaluation-cash-and-food-transfers-earlychildhood-development-centers-karamoja.

Gilligan D O, and Shalini R. (2016). The effect of transfers and preschool on children's cognitive development in Uganda. New Delhi: International Initiative for Impact Evaluation - 3ie, pp.61. Available at: https://reliefweb.int/sites/reliefweb.int/files/resources/ie32-uganda-childdevelopment.pdf.

Ginifer J. (2006). EV663: Internal review of DFID's engagement with the conflict in Northern Uganda. London: DFID, pp.57. Available at: http://www.oecd.org/countries/uganda/36503954.pdf.

Girishankar N, and Achath S. (2002). Implementation completion report for Uganda Institutional Capacity Building Project. Washington, D.C: World Bank, pp.52. Available at:

http://documents1.worldbank.org/curated/en/689091468778224478/pdf/multiOpage. pdf

Glass N, and Doocy S. (2013). Evaluating the Effectiveness of Gender-Based Violence Prevention Programs with Refugees in Uganda. Washington, D.C: US. Department of State, pp.65. Available at: 
http://www.oecd.org/derec/unitedstates/DoS_PRM_GBV_Uganda_Evaluation_Report__Social_Impact.pdf.

Glass N, and Doocy S. (2013). Evaluating the effectiveness of gender-based violence prevention programs with Refugees in Uganda. Washington, D.C: U.S. Department of State, pp.65. Available at:

https://www.oecd.org/derec/unitedstates/DoS_PRM_GBV_Uganda_Evaluation_Report__Social_Impact.pdf.

Glaub M E, Frese M, Fischer S, and Hoppe M. (2014). Increasing Personal Initiative in Small Business Managers or Owners Leads to Entrepreneurial Success: A Theory-Based Controlled Randomized Field Intervention for Evidence-Based Management. Academy of Management Learning \& Education, 13 (3), pp.354-379.

Global Partnership on Out-Based Aid. (2015). Project Completion Report for Kampala Water Connections for the Poor Project. Washington, D.C: GPOBA; WORLD BANK, pp.25. Available at:

http://documents1.worldbank.org/curated/en/457631524486127900/pdf/125603-PCRPUBLIC-P104943-CompletionReportKampalaWaterConnections.pdf.

Global Procurement Consultants Limited. (2013). An Evaluation of the Public Procurement and Disposal Authority (PPDA)'s role in ensuring effectiveness and efficiency of Public Procurement in the National Development Plan Priority Sectors in Uganda. : Office of the Prime Minister

Govindaraj R, and Okwero P. (2003). Implementation completion report for Uganda District Health Project. Washington, D.C: World Bank, pp.61. Available at: http://documents1.worldbank.org/curated/en/707341468779140472/pdf/26049.pdf.

Govindaraj R, and Okwero P. (2003). Implementation completion report for Uganda Sexually Transmitted Infections Project. Washington, D.C: World Bank, pp.59. Available at:

http://documents1.worldbank.org/curated/en/842861468778223505/pdf/26048.pdf.

Gray R H, Kigozi G, Serwadda D, Makumbi F, Nalugoda F, Watya S, Moulton L, Chen M Z, Sewankambo N K, Kiwanuka N, Sempijja V, Lutalo T, Kagayii J, Wabwire M F, Ridzon R, Bacon M, and Wawer M J. (2009). The effects of male circumcision on female partners' genital tract symptoms and vaginal infections in a randomized trial in Rakai, Uganda. American Journal of Obstetrics \& Gynecology, 200(1), pp.42.e1-42.e7.

Gray R H, Kigozi G, Serwadda D, Makumbi F, Watya S, Nalugoda F, Kiwanuka N, Moulton L H, Chaudhary M A, Chen M Z, Sewankambo N K, Wabwire M F, Bacon M C, Williams C F. M, Opendi P, Reynolds S J, Laeyendecker O, Quinn T C, and Wawer M J. (2007). Male circumcision for HIV prevention in men in Rakai, Uganda: a randomised trial. The Lancet, 369(9562), pp.657-666.

Gray R H, Serwadda D, Kong X, Makumbi F, Kigozi G, Gravitt P E, Watya S, Nalugoda F, Ssempijja V, Tobian A A.R, Kiwanuka N, Moulton L H, Sewankambo N K, Reynolds S J, Quinn T C, Iga B, Laeyendecker O, Oliver A E, and Wawer M J. (2010). Male Circumcision Decreases Acquisition and Increases Clearance of High-Risk Human Papillomavirus in 
HIV-Negative Men: A Randomized Trial in Rakai, Uganda. The Journal of Infectious Diseases, 201(10), pp.1455-1462.

Greaney B, Kaboski J P, and Leemput E V. (2016). Can Self-Help Groups Really Be "SelfHelp"? The Review of Economic Studies, 83(4), pp.1614-1644.

Green E P, Blattman C, Jamison J, and Annan J. (2016). Does poverty alleviation decrease depression symptoms in post-conflict settings? A cluster-randomized trial of microenterprise assistance in northern Uganda. Global Mental Health, 3, pp.e7.

Greg F, Karlan D, McConnell M, and PRaffler P. (2018). Short-term Subsidies and Seller Type: A Health. Journal of Development Economics, 137, pp.110-124.

Greg F, Karlan D, McConnell M, and Raffler P. (2016). To Charge or Not to Charge: Evidence from aHealth Products Experiment in Uganda. Massachusetts: NBER, pp.60. Available at:

https://pdfs.semanticscholar.org/b4ae/d6417aec761d75251a2978e0c95e88be506c.pd f.

Greg M, Namusobya S, and Kakande J. (2013). Baseline Study on Democracy, Justice, Human Rights and Accountability in Uganda. Kampala: Democratic Governance Facility, pp.146. Available at:

https://www.dgf.ug/sites/default/files/dgf_publications/DGF\%20Baseline\%20Report_1. pdf.

Grellier R, and Shome P. (2011). FIGO Saving mothers and newborns: Summary evaluation. London: Overseas Development Institute, pp.51. Available at:

https://www.google.com/url?sa=t\&rct=j\&q=\&esrc=s\&source=web\&cd=6\&ved=2ahUKE wijyMKKiMnmAhVr7OAKHVxBDskQFjAFegQIBRAC\&url=https\%3A\%2F\%2Fwww.figo.org \%2Fsites\%2Fdefault\%2Ffiles\%2Fuploads\%2Fproject-

publications\%2FSMN\%2FFinal\%2520Summary\%2520of\%2520All\%2520projects.pdf\&u sg=AOvVaw19bzE4xrsD7samdF8slvGf

Grijsen J G, and Dhalla G H. (2009). Implementation Completion and Results Report for Uganda-Fourth Power Project. Washington, DC: World Bank, pp.64. Available at: http://documents.worldbank.org/curated/en/381721468109737499/Uganda-FourthPower-Project.

Grogan L. (2009). Universal Primary Education and School Entry in Uganda. Journal of African Economies, 18(2), pp.183-211.

Grossman G, Michelitch K, and Santamaria M. (2016). Texting Complaints to Politicians. Name Personalization and Politicians' Encouragement in Citizen Mobilization. Comparative Political Studies, 50(10), pp.1325-1357.

Grossman G, Platas M, and Rodden J. (2017). Can text messages improve local governance?: an impact evaluation of the U-bridge program in Uganda. Washington, D.C: USAID, pp.129. Available at: https://pdf.usaid.gov/pdf_docs/PA00N1TC.pdf. 
Gupta N, Katende C, and Bessinger R. (2004). An evaluation of post-campaign knowledge and practices of exclusive breastfeeding in Uganda. Journal of Health, and Population and Nutrition, 22(4), pp.429-439.

Gwali S. (2014). Ecosystem Based Adaptation to Climate Change (EBA) Project. Mid Term Review Report. New York: United Nations Development Programme (UNDP), pp.63. Available at: https://erc.undp.org/evaluation/documents/detail/8584.

Haberer J E, Musiimenta A, Atukunda E C, Musinguzi N, Wyatt M A, Ware N C, and Bangsberg D R. (2016). Short message service (SMS) reminders and real-time adherence monitoring improve antiretroviral therapy adherence in rural Uganda. AIDS, 30(8), pp.1295-1299.

Habermehl H. (2007). Economic evaluation of the improved household cooking stove dissemination programme in Uganda. New York: UNDP, pp.44. Available at: https://energypedia.info/images/1/1a/Economic_Evaluation_of_the_Improved_Househ old_Cooking_Stove_Dissemination_Programme_in_Uganda_v02_2007_.pdf.

Harou P. (2008). Project Performance Assessment Report for Uganda-Environmental Management and Capacity Building Project. Washington, D.C: World Bank, pp.42. Available at:

http://documents1.worldbank.org/curated/en/661631468110939827/pdf/441950PPAR OP001closed0August0702008.pdf.

Hartmann I, Bemigisha J, Nyiramahoro D E, and Makuma H M. (2013). Mid Term Evaluation of Mainstreaming Sustainable Land Management (SLM) In Cattle Corridor Project. New York: United Nations Development Programme, pp.110. Available at: https://erc.undp.org/evaluation/documents/detail/7147.

Hartmann I, Bemigisha J, Nyiramahoro D E, and Makuma H M. (2013). Report of the Midterm Evaluation of the Mainstreaming of Sustainable Land Management Policies in Six Cattle Corridors of Uganda. New York: United Nations Development Programme, pp.110. Available at: https://erc.undp.org/evaluation/documents/detail/8104.

Hecht J, ECODIT, and Mitchell A. (2014). Global sustainable tourism alliance (GSTA) performance evaluation: final report. New York: USAID, pp.44. Available at: https://pdf.usaid.gov/pdf_docs/PA00K43K.pdf.

Hemson D, Caplan K, Monschein S, and Voglozin N. (2018). Evaluation: final performance evaluation of securing water for food grand challenge for development (SWFF). Washington, D.C: USAID, pp.70. Available at: https://pdf.usaid.gov/pdf_docs/PA00TDPS.pdf.

Heugh K, and Bwanika M. (2013). An Evaluation of the Literacy and Basic Education (LABE) Mother-Tongue Education (MTE) Project, Uganda Final Report. Paris: UNESCO, pp.73. Available at: https://pdfs.semanticscholar.org/133d/f66db3802ab4e5ec972c08a2ec9aef4a8596.pdf.

Hiroshi S. (2013). Implementation Completion and Results Report for A Millennium Science Initiative Project. Washington, D.C: World Bank, pp.73. Available at: 
http://documents.worldbank.org/curated/en/527611468115451672/UgandaMillennium-Science-Initiative-Project.

Hirschmann D, and Nyago K. (2003). Evaluation of the Uganda parliament technical assistance project (UPTAP). Washington, D.C: USAID, pp.55. Available at: https://pdf.usaid.gov/pdf_docs/PDACF477.pdf.

Hjálmarsdóttir E H, and Kharono E. (2013). External evaluation on the Development of a short course on Gender and Climate Change (G\&CC). Oslo: Norwegian Embassy, pp.117. Available at:

http://www.oecd.org/derec/iceland/21_ICELANDevelopment_TrainingCourseGenderCli mateChangeUganda20112013.pdf.

Hoffmann V. (2009). Intrahousehold Allocation of Free and Purchased Mosquito Nets. American Economic Review, 99(2), pp.236-41.

Homsy J, Grant D, Arinaitwe E, Wanzira H, Kakuru A, Bigira V, Muhindo M, Kamya M R, Sandison T G, and Tappero J W. (2014). Protective efficacy of prolonged co-trimoxazole prophylaxis in HIV-exposed children up to age 4 years for the prevention of malaria in Uganda: A randomised controlled open-label trial. The Lancet Global Health, 2 (12), pp.e727-e736.

Hotz C, Loechl C, Lubowa A, Tumwine J K, Ndeezi G, Nandutu M A, Baingana R, Carriquiry A, De Brauw A, Jonnalagadda V M, and Gilligan D O. (2012). Introduction of $\beta$-CaroteneRich Orange Sweet Potato in Rural Uganda Resulted in Increased Vitamin A Intakes among Children and Women and Improved Vitamin A Status among Children. The Journal of Nutrition, 142(10), pp.1871-1880.

Hulsman V M, and Sterkenburg J. (2003). Co-ordination and sector support: An evaluation of the Netherlands' support to local governance in Uganda 1991 - 2001. Amsterdam: Policy and Operations Evaluation Department (IOB), pp.135. Available at: http://www.oecd.org/countries/uganda/35149025.pdf.

ICAI. (2018). DFID's governance work in Nepal and Uganda: a performance review. London: ICAI, pp.52. Available at: https://icai.independent.gov.uk/html-report/dfidsgovernance-work-in-nepal-and-uganda/.

Igbokwe C M, Abramsky T, Karen D, Lori M, Musuya T, and Watts C. (2016). Cost and costeffectiveness analysis of a community mobilisation intervention to reduce intimate partner violence in Kampala, Uganda. BioMed Central Public Health, 16(1), pp.196.

Inayatullah C, and Kakuru W. (2013). Extending Wetland Protected Areas Through Community Conservation Initiatives [COBWEB]. New York: United Nations Development Programme, pp.90. Available at: https://erc.undp.org/evaluation/documents/detail/7894.

Inayatullah C, Kayanga S T, and Ssejjemba K. (2016). Enhancing Adoption of Climate Smart Agriculture Practices in Uganda's Farming Systems. : United Nations Development Programme. Available at: https://erc.undp.org/evaluation/documents/detail/9527. 
Independent Evaluation Group and Operations Evaluation Department. (2009). Joint IEG/OPEV Country Assistance Evaluation. Abidjan: African Development Bank, pp.174. Available at: http://idev.afdb.org/sites/default/files/Evaluations/2020-03/20012007\%20-\%20Uganda\%20-\%20Country\%20Assistance\%20Evaluation.pdf.

Independent Evaluation Group, and Operation Evaluation Department. (2009). 2001-2007 Uganda - Country Assistance Evaluation. Abidjan: African Development Bank, pp.174. Available at: https://www.afdb.org/en/documents/document/2001-2007-ugandacountry-assistance-evaluation-16779.

Infectious Diseases Institute Uganda. (2018). The Global Fund Prospective Country Evaluation: Uganda report. Geneva: Path, pp.12. Available at: https://www.path.org/resources/global-fund-prospective-country-evaluation-uganda2019-annual-report/.

Infield M, and Namara A. (2009). Community attitudes and behaviour towards conservation: an assessment of a community conservation programme around Lake Mburo National Park, Uganda. Oryx, 35(1), pp.48-60.

International Business Technical Consultants. (2014). Performance evaluation of USAID/Uganda capacity program. Washington, D.C: USAID, pp.82. Available at: https://pdf.usaid.gov/pdf_docs/PA00JRCP.pdf .

Ismayilova L, Ssewamala F M, and Karimli L. (2012). Family Support as a Mediator of Change in Sexual Risk-Taking Attitudes Among Orphaned Adolescents in Rural Uganda. Journal of Adolescent Health, 50(3), pp.228-235.

Ivar S. (2005). Simplified implementation completion report for Uganda - First Poverty Reduction Support Credit (PRSC1) . Washington, D.C: World Bank, pp.6. Available at: http://documents.worldbank.org/curated/en/997811468781777434/Uganda-FirstPoverty-Reduction-Support-Credit-PRSC1.

Ivar S. (2005). Simplified implementation completion report for Uganda - Second Poverty Reduction Support Credit (PRSC2) . Washington, D.C: World Bank, pp.6. Available at: http://documents1.worldbank.org/curated/en/669231468778471826/pdf/31762.pdf.

Jack B A, Kirton J, Birakurataki J, and Merriman A. (2011). A bridge to the hospice': The impact of a Community Volunteer Programme in Uganda. Palliative Medicine, 27(7), pp.706-715.

Jacob W J. (2007). Evaluating HIV/AIDS education programmes in Ugandan secondary schools. Paris: UNESCO, pp.2. Available at: https://aphanew.confex.com/apha/131am/techprogram/paper_67356.htm.

Jaffar S, Birungi J, Grosskurth H, Amuron B, Namara G, Nabiryo C, and Coutinho A. (2008). Use of WHO clinical stage for assessing patient eligibility to antiretroviral therapy in a routine health service setting in Jinja, Uganda. AIDS research and therapy, 5(1), pp.4.

Jäger M. (2007). Evaluation of the Education Sector of ADC - Annex 6.2: Country Report Uganda. Vienna: Austrian Development Agency, pp.31. Available at: http://www.oecd.org/countries/ethiopia/39736516.pdf. 
Jallow A T.B, and Englert A. (2011). Final Report of the Final Evaluation of the Government of Uganda and UNDP Crisis Management and Recovery Program (CMR). New York: United Nations Development Programme, pp.105. Available at: https://erc.undp.org/evaluation/documents/detail/5296.

Jamison J C, Karlan D, and Raffler P. (2013). Mixed method evaluation of a passive mHealth sexual. Washington, DC: Center for Global Development 1800 Massachusetts Ave., NW Washington, DC, pp.37. Available at: https://www.nber.org/system/files/working_papers/w19107/w19107.pdf.

Jamison J C, Karlan D, and Zinman J. (2014). Financial Education and Access to Savings Accounts: Complements or Substitutes? Evidence from Ugandan Youth Clubs. Massachusetts: NBER, pp.40. Available at: https://www.dartmouth.edu/ jzinman/Papers/SaLSa_Full_2014_05.pdf.

Jayachandran S. (2013). Liquidity Constraints and Deforestation: The Limitations of Payments for Ecosystem Services. American Economic Review, 103, pp.309-313.

Jayachandran S, Laat J D, Lambin E F, Stanton C Y, Audy R, and Thomas N E. (2017). Cash for carbon: A randomized trial of payments for ecosystem services to reduce deforestation. Science, 357 (6348), pp.267-273.

Jayawickrama M S, and Kshirsagar V. (2010). Implementation Completion and Results Report for Uganda - National Agricultural Advisory Services Project. New York: World Bank, pp.75. Available at: http://documents.worldbank.org/curated/en/892271468110673938/Uganda-NationalAgricultural-Advisory-Services-Project.

Jelenic M C. (2015). Implementation Completion and Results Report for A Public Service Performance Enhancement Project. Washington, D.C: World Bank, pp.66. Available at: http://documents1.worldbank.org/curated/en/336481468103473803/pdf/ICR32660P0 50440ICOdisclosed03020150.pdf.

Jennings L, Ssewamala F M, and Nabunya P. (2016). Effect of savings-led economic empowerment on HIV preventive practices among orphaned adolescents in rural Uganda: results from the Suubi-Maka randomized experiment. AIDS CARE, 28(3), pp.273-282.

Jilcott S B, Ickes S B, and Ammerman A S. (2009). Iterative Design, Implementation and Evaluation of a Supplemental Feeding Program for Underweight Children Ages 6-59 Months in Western Uganda. Matern Child Health J, 14(2), pp.299-306.

Jimat Consult. (2011). Evaluation of the Paris Declaration - Phase 2 - Uganda. Vienna: Austrian Development Agency, pp.146. Available at: http://www.oecd.org/countries/uganda/47673315.pdf.

Jodi M, Berrino A, Jordans M J, Okema L, Crow C, and Jones L. (2012). Does Combining Infant Stimulation with Emergency Feeding Improve Psychosocial Outcomes for Displaced Mothers and Babies? A Controlled Evaluation from Northern Uganda. American Journal of Orthopsychiatry, 82(3), pp.349-357. 
John Snow Inc. (2012). Exploring the effects of holistic capacity building: an evaluation of NuPITA's technical assistance on NPI partners' service delivery and sustainability. Washington, D.C: USAID, pp.93. Available at: https://pdf.usaid.gov/pdf_docs/PDACX456.pdf.

Johnson N W, and Karen R. (2001). Implementation completion report for Uganda - Bwindi Impenetrable National Park and Mgahinga Gorilla National Park Conservation Park Project. Washington, D.C: World Bank, pp.27. Available at: http://documents1.worldbank.org/curated/en/765191468779171339/pdf/multiOpage. pdf.

Jouanjean M A, and Te Velde D.W. (2013). The Role of Development Finance Institutions in Promoting Jobs and Structural Transformation: A Quantitative Assessment. London: Overseas Development Institute, pp.61. Available at: https://www.odi.org/sites/odi.org.uk/files/odi-assets/publications-opinionfiles/8323.pdf.

Kaari E, Maganya G, Wangoolo J, Kamau C, and Karungi C. (2016). Evaluation of the DFID Funded "Enhancing Resilience in Karamoja Programme (ERKP)". Rome: World Food Programme, pp.132. Available at:

https://docs.wfp.org/api/documents/c5b7c9e06f0b471 ca630ecafec1 aef51/download/.

Kabahenda M, Mullis R M, Erhardt J G, Northrop C C, and Nickols S Y. (2011). Nutrition education to improve dietary intake and micronutrient nutriture among children in less-resourced areas: a randomised controlled intervention in Kabarole district, western Uganda. South African Journal of Clinical Nutrition, 24(2), pp.83-88.

Kabakyenga J, Barigye C, Brenner J, Maling S, Buchner D, Nettle-Aquirre A, and MacLeod S. (2016). A demonstration of mobile phone deployment to support the treatment of acutely ill children under five in Bushenyi district, Uganda. African Health Sciences, 16(1), pp.89-96.

Kabunga N, Mogues T, Bizimungu E, Erman A, and Campenhout B V. (2015). The State of Public Service Delivery in Uganda - Report of a Baseline Survey for the Baraza Impact Evaluation. Washington, D.C: International Food Policy Research Institute, pp.50. Available at: http://www.ifpri.org/publication/state-public-service-delivery-ugandareport-baseline-survey.

Kagulire S C, Opendi P, Stamper P D, Nakavuma J L, Mills L A, Makumbi F, R H Gray, R.H, Shott J P, Serwadda D, and Reynolds SJ. (2011). Field evaluation of five rapid diagnostic tests for screening of HIV-1 infections in rural Rakai, Uganda. International Journal of STD \& AIDS, 22(6), pp.308-309.

Kahangirwe P. (2011). Evaluation of environmental impact assessment (EIA) practice in Western Uganda. Impact Assessment and Project Appraisal, 29(1), pp.79-83.

Kahn C, Iraguha M, Baganizi M, Kolenic G E, Paccione G A, and Tejani N. (2015). Cash Transfers to Increase Antenatal Care Utilization in Kisoro, Uganda: A Pilot Study. African Journal of Reproductive Health, 19(3), pp.144-150. 
Kakaire O, Byamugisha J K, Tumwesigye N M, and Kristina Gemzell D.K. (2015). Clinical versus laboratory screening for sexually transmitted infections prior to insertion of intrauterine contraception among women living with HIV/AIDS: a randomized controlled trial. Human Reproduction, 30 (7), pp.1573-1579.

Kakande M, Nayenga R, Olsson A, Lubuulwa M, Basaasira S A, Muwereza M, Mugabi D, Mwebembezi J, Kawongolo M M, and Nsubuga C. (2012). Financing the Food Security Budget in the National Agricultural Advisory Services - Adequacy and Impacts in a decentralized system. Kampala: Ministry of Finance, Planning and Economic Development - Budget Monitoring and Accountability Unit (BMAU), pp.111. Available at: https://searchworks.stanford.edu/view/9719736.

Kalyango J N, Lindstrand A, Rutebemberwa E, Ssali S, Kadobera D, Karamagi C, Peterson S, and Alfven T. (2012). Increased Use of Community Medicine Distributors and Rational Use of Drugs in Children Less than Five Years of Age in Uganda Caused by Integrated Community Case Management of Fever. American Journal of Tropical Medicine and Hygiene, 87, pp.36-45.

Kamali A, Quigley M, Nakiyingi J, Kinsman J, Kengeya-Kayondo J, Gopal R, Ojwiya A, Hughes P, Carpenter LM, and Whitworth J. (2003). Syndromic management of sexuallytransmitted infections and behaviour change interventions on transmission of HIV-1 in rural Uganda: a community randomised trial. The Lancet, 361(9358), pp.645-652.

Kamu R K. (2012). Implementation Completion and Results Report for Uganda-Power Sector Development Operation. Washington, D.C: World Bank, pp.52. Available at: http://documents.worldbank.org/curated/en/869561468112750210/Uganda-PowerSector-Development-Operation-Project.

Kamya M R, Kapisi J, Bigira V, Clark T D, Kinara S, Mwangwa F, Muhindo M K, Kakuru A, Aweeka F T, Huang L, Jagannathan P, Achan J, Havlir D V, Rosenthal P J, and Dorsey G. (2014). Efficacy and safety of three regimens for the prevention of malaria in young HIV-exposed Ugandan children: a randomized controlled trial. OVID Journals, 28 (18), pp.2701-2709.

Kapiriri S M, and Muhereza F. (2002). Uganda conserve biodiversity for sustainable development (COBS) support project: project final evaluation. Washington, D.C: USAID, pp.86. Available at: https://pdf.usaid.gov/pdf_docs/PDABX296.pdf.

Karamagi C A, Lubanga R G, Kiguli S, Ekwaru P J, and Heggenhougen K. (2004). Health Providers' Counselling of Caregivers in the Integrated Management of Childhood Illness (IMCI) Programme in Uganda. African health sciences, 4(1), pp.31-39.

Karen A, and Muthengi E. (2014). Can economic assets increase girls' risk of sexual harassment? Evaluation results from a social, health and economic asset-building intervention for vulnerable adolescent girls in Uganda. Children and Youth Services Review, 47, pp.168-175.

Karen R, and Ruitenbeek J. (2003). Uganda - Institutional Capacity Building for Protected Areas Management and Sustainable Use Project. Washington, D.C: World Bank, pp.42. Available at: 
http://documents.worldbank.org/curated/en/343131468760551685/UgandaInstitutional-Capacity-Building-for-Protected-Areas-Management-and-Sustainable-UseProject.

Karen R, and Ruitenbeek J. (2003). Implementation completion report for Uganda Institutional Capacity Building for Protected Areas Project. Washington, D.C: World Bank, pp.39. Available at: http://documents.worldbank.org/curated/en/930901468779140077/UgandaInstitutional-Capacity-Building-for-Protected-Areas-Project.

Karim A M, Williams T, Patykewich L, Ali D, Colvin C E, Posner J, and Rutaremwa G. (2009). The Impact of the African Youth Alliance Program on the Sexual Behavior of Young People in Uganda. Studies in Family Planning, 40(4), pp.289-306.

Karimli L, Ssewamala F M, and Neil T B. (2014). Poor Families Striving to Save in Matched Children's Savings Accounts: Findings from a Randomized Experimental Design in Uganda. Social Service Review, 88(4), pp.658-694.

Karl W, Juerg C, and Deirdre C. (2003). Evaluation of Austria's Development Cooperation and Assistance to CEECS/NIS in the Water Sector (Water Supply and Sanitation). Vienna: Austria's Development Cooperation, pp.148. Available at: http://www.oecd.org/countries/albania/35129363.pdf.

Karlan D, and Linden L L. (2014). Loose Knots: Strong Versus Weak Commitments to Save for Education in Uganda. Massachusetts: NBER, pp.34. Available at: https://ageconsearch.umn.edu/record/162693/files/cdp1037.pdf.

Karpinska Z. (2008). An Evaluation of the INEE Minimum Standards for Education in Emergencies, Chronic Crises and Early Reconstruction: A Uganda Case Study. Washington, D.C: Education Resources Information Centerhttps, pp.34. Available at: https://eric.ed.gov/?id=ED535315.

Kassie M, Shiferaw B, and Muricho G. (2011). Agricultural Technology, Crop Income, and Poverty Alleviation in Uganda. World Development, 39(10), pp.1784-1795.

Katabarwa M N, Habomugisha P, and Richards F O. (2002). Implementing communitydirected treatment with ivermectin for the control of onchocerciasis in Uganda (19972000): an evaluation. Annals of tropical medicine and parasitology, 96(1), pp.61-73.

Katende C, Gupta N, and Bessinger R. (2002). The Impact of a Reproductive Health Project Interventions on Contraceptive Use in Uganda. North Carolina: Measure evaluation, pp.30. Available at:

https://www.google.com/url?sa=t\&rct=j\&q=\&esrc=s\&source=web\&cd=1\&ved=2ahUKE wjNjOupO-

HIAhXRYIAKHRCBD6MQFjAAegQICBAC\&url=https\%3A\%2F\%2Fwww.measureevaluation .org\%2Fresources\%2Fpublications\%2Fwp-02-

49\%2Fat_download\%2Fdocument\&usg=AOvVaw3DTx6RA8XI4_wTzQOw7j31.

Kato E, Nkonya E, Place F, and Mwanjalola M. (2010). An Econometric Investigation of Sustainable Land Management Practices on Soil Carbon and Yield Risk: A Potential for 
Climate Change Mitigation. International Food Policy Research Institute (IFPRI), December 2010, andWorking Paper 01038, pp.24.

Katorobo J, Sengendo M, and Kalibwani R J. (2005). Evaluation of increased Public Sector Efficiency, Transparency and Accountability. New York: United Nations Development Programme, pp.106. Available at:

https://erc.undp.org/evaluation/documents/detail/287.

Katzensteina D, Lagab M, and Moattic J P. (2003). The evaluation of the HIV/AIDS Drug Access Initiatives in Côte D'Ivoire, Senegal and Uganda: how access to antiretroviral treatment can become feasible in Africa. AIDS, 17, pp.S1-S4.

Kavalsky B, and Carrizosa M. (2010). World Bank Economic Reports on Growth Diagnostics in Four African Countries: Ghana, Mauritius, Nigeria, And Uganda. Washington, D.C: World Bank, pp.114. Available at: http://documents.worldbank.org/curated/en/911141468000913726/World-Bankeconomic-reports-on-growth-diagnostics-in-four-African-countries-Ghana-MauritiusNigeria-and-Uganda.

Kavuma R M. (2012). Support to media where media freedoms and rights are constrained. London: BBC Media Action, pp.440. Available at: http://downloads.bbc.co.uk/mediaaction/pdf/uganda.pdf.

Kayongo B. (2005). Multintional - Fifth Line of Credit to the East African Development Bank Completion Report. Abidjan: African Development Bank, pp.46. Available at: https://www.afdb.org/fileadmin/uploads/afdb/Documents/Project-andOperations/ADB-BD-IF-2005-303-EN-MULTINATIONAL-PCR-EADB-LOC-V.PDF.

Kemp A. (2008). Analysing the Effectiveness of Sector Support: Primary Education in Uganda and Zambia. IDS Bulletin, 39(1), pp.36-50.

Kibirige M, and Hume S. (2013). Implementation Completion and Results Report for A Uganda Second Private Sector Competitiveness Project. Washington, D.C: World Bank, pp.81. Available at: http://documents.worldbank.org/curated/en/987861468318299302/Uganda-SecondPrivate-Sector-Competitiveness-Project.

Kibombo R, Owarwo V, Nuamanya A, Nasreen J, and Otikal K. (2016). Evaluation of USAID/Uganda strengthening decentralization for sustainability (SDS) program. Washington, D.C: USAID, pp.170. Available at: https://pdf.usaid.gov/pdf_docs/PA00M7SR.pdf.

Kiggundu M, Nsobya S L, Kamya M R, Filler S, Nasr S, Dorsey G, and Yeka A. (2011). Evaluation of a Comprehensive Refresher Training Program in Malaria Microscopy Covering Four Districts of Uganda. The American Journal of Tropical Medicine and Hygiene, 84(5), pp.820-824.

Kigozi G, Watya S, Polis C B, Buwembo D, Kiggundu V, Wawer M J, Serwadda D, Nalugoda F, Kiwanuka N, Bacon M C, Ssempijja V, Makumbi F, and Gray R H. (2008). The effect of male circumcision on sexual satisfaction and function, results from a randomized trial 
of male circumcision for human immunodeficiency virus prevention, Rakai, Uganda. BJU International, 101(1), pp.65-70.

Kiiza B, and Glenn P. (2012). ICT-based market information and adoption of agricultural seed technologies: Insights from Uganda. Telecommunications Policy, 36(4), pp.253259.

Kijima Y. (2014). Enhancing Rice Production in Uganda: Impact Evaluation of a Training Program and Guidebook Distribution in Uganda. Tokyo: Japan International Cooperation Agency; Research Institute, pp.39. Available at: https://www.jica.go.jp/jicari/publication/workingpaper/jrft3q00000025qp-att/JICA-RI_WP_No.80.pdf.

Kijima Y, Ito Y, and Otsuka K. (2012). Assessing the Impact of Training on Lowland Rice Productivity in an African Setting: Evidence from Uganda. World Development, 40(8), pp.1610-1618.

Kilian A, Balay C, Feldman M, Koenker H, Lokko K, Ashton R A, Bruce J, Lynch M, and Boulay $M$. (2015). The effect of single or repeated home visits on the hanging and use of insecticide-treated mosquito nets following a mass distribution campaign--a cluster randomized, controlled trial. PLoS ONE, 10(3), pp.e0119078.

Kim Y M, Kalibala S, Neema S, Lukwago J, and Weiss D C. (2012). Meaningful involvement of people living with HIVIAIDS in Uganda through linkages between network groups and health facilities: An evaluation study. Psychology, and Health \& Medicine, 17(2), pp.213-222.

Kinsman J, Kamali A, Kanyesigye E, Kamulegeya I, Basajja V, Nakiyingi J, and Whitworth J. (2002). Quantitative process evaluation of a community-based HIV/AIDS behavioural intervention in rural Uganda. Health Education Research, 17(2), pp. 253-265.

Kinsman J, Nakiyingi J, Kamali A, Carpenter L, Quigley M, Pool R, and Whitworth J. (2001). Evaluation of a comprehensive school-based aids education programme in rural Masaka, Uganda. Health Education Research, 16, pp.85-100.

Kintu Nyago, Laura Nyirikindi, and Jeremias Blaser. (2005). UNV Support to the Promotion of Human Rights Project in Uganda. New York: United Nations Development Programme. Available at: https://erc.undp.org/evaluation/documents/detail/292.

Kintu R M. (2016). Youth entrepreneurship facility in Uganda. Geneva: ILO, pp.1. Available at: https://www.ilo.org/ievaldiscovery/\#a2d44y.

Kiran K, Muheki C, Cazemier J, Sebuwufu D, and Ssali G. (2018). Evaluation of the USAID/Uganda private health support (PHS) program. Washington, D.C: USAID, pp.104. Available at: https://pdf.usaid.gov/pdf_docs/PA00TDFC.pdf.

Kittelsen T V, and Okungu P. (2007). Evaluation of The Uganda National Association of the Blind. Oslo: Norad: Norad, pp.38. Available at: https://norad.no/ombistand/publikasjon/ngo-evaluations/2009/evaluation-of-the-uganda-nationalassociation-of-the-blind/.

Kivumbi H, Azuba R, Bukenya J, and Nabembezi D. (2013). End of project evaluation: Hospice Africa Uganda (HAU) program: 'expanding the access to and scope of palliative care for 
people living with HIV/AIDS (PLHIV) and their families' -- final report. Washington, D.C: USAID, pp.68. Available at: https://pdf.usaid.gov/pdf_docs/PDACX654.pdf.

Kiweewa F M, Wabwire D, Nakibuuka J, Mubiru M Bagenda D, M, and Antelman G. (2013). Noninferiority of a Task-Shifting HIV Care and Treatment Model Using Peer Counselors and Nurses Among Ugandan Women Initiated on ART: Evidence from a Randomized Trial. JAIDS Journal of Acquired Immune Deficiency Syndromes, 63 (4), pp.e125-e132.

Kjellström E, Makara S, and Sjöberg P. (2009). Party Cooperation in a Results Perspective Uganda. Stockholm: Swedish Agency for Development Evaluation, pp.51. Available at: http://www.oecd.org/countries/uganda/uganda.pdf.

Kraus C. (2002). Implementation completion report for Uganda - Third Structural Adjustment Credit Project. Washington, D.C: World Bank, pp.39. Available at: http://documents.worldbank.org/curated/en/825671468309301268/Uganda-ThirdStructural-Adjustment-Credit-Project.

Kruk M E, Rabkin M, Grépin K A, Austin E K, Greeson D, Masvawure T B, and Galea S. (2014). 'Big Push' To Reduce Maternal Mortality in Uganda And Zambia Enhanced Health Systems But Lacked A Sustainability Plan. Health Affairs, 33(6), pp.1058-1066.

Kruk M E, Vail D, Austin E K, Atuyambe L, and Grees D. (2016). Evaluation of a maternal health program in Uganda and Zambia finds mixed results on quality of care and satisfaction. Health Affairs, 35(3), pp.510-519.

Kruse S E. (2009). Exploring Donorship - Internal Factors In Swedish Aid To Uganda. Stocklhom: Expertgruppen för biståndsanalys (EBA), pp.120. Available at: http://www.oecd.org/derec/sweden/Uganda-201609-webb.pdf.

Kumakech E, Cantor G E, Maling S, and Bajunirwe F. (2009). Peer-group support intervention improves the psychosocial well-being of AIDS orphans: Cluster randomized trial. Social Science \& Medicine, 68(6), pp.1038-1043.

Kunutsor S, Walley J, Katabira E, Muchuro S, Balidawa H, Namagala E, and Ikoona E. (2011). Improving Clinic Attendance and Adherence to Antiretroviral Therapy Through a Treatment Supporter Intervention in Uganda: A Randomized Controlled Trial. AIDS \&, and Behavior, 15(8), pp.1795-1802.

Kuper K. (2004). Implementation completion report for Uganda - Local Government Development Program. Washington, D.C: World Bank, pp.52. Available at: http://documents.worldbank.org/curated/en/765221468760552638/Uganda-LocalGovernment-Development-Program.

Kuper K. (2004). Implementation completion report for Uganda - Nakivubo Channel Rehabilitation Project. Washington, D.C: World Bank, pp.52. Available at: http://documents.worldbank.org/curated/en/308281468310140350/UgandaNakivubo-Channel-Rehabilitation-Project.

Lakuma C P, Katunze M, Nagawa M, Mawejje J, Lwanga M, Mbowa S, and Shinyekwa I. (2017). Country Reviews of Capacity Development: The Case Of Uganda. Kampala: Economic Policy Research Centre, pp.88. Available at: 
https://ageconsearch.umn.edu/record/257819/files/41\%20Country\%20reviews\%20of\% 20capacity\%20development-the\%20case\%20of\%20Uganda.pdf.

Lalonde A B, Okong P, Mugasa A, and Perron L. (2003). The FIGO Save the Mothers Initiative: The Uganda-Canada collaboration. Obstetrics and Gynecology, 80(2), pp.204-212.

LeBlanc R N, Kaeppler R, Hennion M, Nkutu R, Nsubuga D, and Kirkemann P. (2009). Country Level Evaluation Uganda. Brussels: EU - EuropeAid Cooperation Office (AIDCO), pp.93. Available at: http://www.oecd.org/countries/uganda/44653135.pdf.

Leerlooijer J N, Bos A E. R, Ruiter R A. C, van Reeuwijk M A. J, Rijsdijk L E, Nshakira N, and Kok G. (2013). Qualitative evaluation of the Teenage Mothers Project in Uganda: a community-based empowerment intervention for unmarried teenage mothers. BMC Public Health, 13(1), pp.816.

Lekoetje D, Isooba D, and Kayongo B. (2013). Uganda - Mineral Resources Management and Capacity Building Project - Project Completion Report. Abidjan: African Development Bank, pp.27. Available at:

https://www.afdb.org/fileadmin/uploads/afdb/Documents/Project-and-

Operations/Uganda_-

_Mineral_Resources_Management_and_Capacity_Building_Project_-

Project_Completion_Report.pdf.

Leliveld A. (2006). Volume III - Background Papers - Evaluation of Danish Aid to Uganda

1987-2005. Hague: Policy and Operations Evaluation Department (IOB), pp.110.

Available at: http://www.oecd.org/countries/uganda/39437825.pdf.

Leliveld A. (2006). Evaluation of the Implementation of the Sector-Wide Approach in Bilateral Aid - Uganda. Hague: Policy and Operations Evaluation, pp.110. Available at: http://www.oecd.org/countries/uganda/39437825.pdf.

Lenoci J, and Wasige J. (2014). Terminal Evaluation: Mainstreaming Sustainable Land Management Activities in Six Cattle Corridor Districts of Uganda. New York: United Nations Development Programme, pp.110. Available at: https://erc.undp.org/evaluation/documents/detail/7898.

Levine D I, and Cotterman C. (2012). What Impedes Efficient Adoption of Products? Evidence from Randomized Variation in Sales Offers for Improved Cookstoves in Uganda. Institute of Industrial Relations, UC Berkeley, and Working Paper Series., 117, pp.127135.

Lister S, Baryabanoha W, Steffensen J, and Williamson T. (2016). Joint evaluation of general budget support 1994-2004. Birmingham: International Development Department, pp.185. Available at:

https://assets.publishing.service.gov.uk/government/uploads/system/uploads/attach ment_data/file/67832/gbs-uganda.pdf.

Lister S, Oates P, Ogeda M, and Bjormestad . (2003). Evaluation of the Uganda Country Strategy 2000-2003. Dublin: Development Coopeartion Ireland, pp.37. Available at: http://www.oecd.org/countries/uganda/35273882.pdf. 
Lochhead D, and Musoke R A. (2010). Evaluation of the 'Building Sustainable Peace and Development Project in Karamoja'. New York: United Nations Development Programme, pp.88. Available at: https://erc.undp.org/evaluation/documents/detail/4147.

Lombardini S, and Yoshikawa K. (2015). Women's Empowerment in Uganda: Impact evaluation of the project piloting gender sensitive livelihood in Karamoja. Nairobi: Oxfam, pp.74. Available at: https://oxfamilibrary.openrepository.com/bitstream/handle/10546/592575/erwomens-empowerment-uganda-ef_1? sequence $=6$.

López-Carr D, Kibombo R, Ondego D, and Asiimwe W. (2018). Health of the people and environment in the Lake Victoria Basin (HOPE-LVB) project evaluation: solutions for healthy people and a healthy planet. New York: USAID, pp.142. Available at: https://pdf.usaid.gov/pdf_docs/PA00SZB4.pdf.

Lubega M, Tumwesigye N M, Kadobera D, Marrone G, Wabwire M F, Pariyo G, Peterson S, and Ekstrom A M. (2011). A Single-Blind Randomized Controlled Trial to Evaluate the Effect of Extended Counseling on Uptake of Pre-Antiretroviral Care in Eastern Uganda. Trials, 12(1), pp.184.

Lubega M, Tumwesigye N M, Kadobera D, Marrone G, Wabwire M F, Peterson S, Reynolds S J, and Ekstrom A M. (2015). Effect of Community Support Agents on Retention of People Living with HIV in Pre-antiretroviral Care: A Randomized Controlled Trial in Eastern Uganda. JAIDS (Journal of Acquired Immune Deficiency Syndromes), 70(2), pp.e36-e43.

Lucas A M, McEwan P J, Ngware M, and Oketch M. (2014). Improving early grade-grade literacy in East Africa: Experimental evidence from Kenya and Uganda. Journal of Policy Analysis and Management, 33(4), pp.950-976.

Lugada E, Levin J, Abang B, Mermin J, Mugalanzi E, Namara G, Gupta S, Grosskurth H, Jaffar S, Coutinho A, and Bunnell R. (2010). Comparison of Home and Clinic-Based HIV Testing Among Household Members of Persons Taking Antiretroviral Therapy in Uganda: Results from a Randomized Trial. JAIDS Journal of Acquired Immune Deficiency Syndromes, 55(2), pp.245-52.

Lule J R, Mermin J, Ekwaru J P, Malamba S, Downing R, Ransom R, Nakanjako D, Wafula W, Hughes P, Bunnell R, Kaharuza F, Coutinho A, Kigozi A, and Quick R. (2005). Effect of home-based water chlorination and safe storage on diarrhea among persons with human immunodeficiency virus in Uganda. The American Journal of Tropical Medicine and Hygiene, 73(5), pp.926-933.

Lumbwe C, Lars T F, Ingunn E, Tumwine J, Tylleskar T, and Robberstad B. (2013). Infant Feeding Survival and Markov Transition Probabilities Among Children Under Age 6 Months in Uganda. American Journal of Epidemiology, 177(5), pp.453-462.

Lutalo T, Kigozi G, Kimera E, Serwadda D, Wawer M J, Zabin L S, and Gray R H. (2010). A Randomized Community Trial of Enhanced Family Planning Outreach in Rakai, Uganda. Studies in Family Planning, 41(1), pp.55-60. 
Lwasa S, Lwanga G M, Bitwayiki C, Ibanda S J, Munalitsi A, Uwimana J, and Masanyu A. (2015). Support for Development of Inclusive Markets in Agriculture and Trade (DIMAT) Project (2011-2015). New York: United Nations Development Programme, pp.122. Available at: https://erc.undp.org/evaluation/documents/detail/9004.

Lynd M. (2007). Evaluation of the REPLICA project. Washington, D.C: USAID, pp.82. Available at: https://pdf.usaid.gov/pdf_docs/PDACQ503.pdf.

Mabiriizi F. (2010). The Uganda/UNDP/UNEP Partnership Initiative for The Implementation of Strategic Approach to International Chemicals Management (SAICM) Project (April, 2008 - October, 2009 - Extendable). New York: United Nations Development Program Country Office, pp.84. Available at: https://erc.undp.org/evaluation/documents/detail/4061.

Mahmud I, and Mensah J. (2017). Implementation completion and results report for Uganda health systems strengthening project. Washington, D.C: World Bank, pp.83. Available at:

http://documents.worldbank.org/curated/en/140811514912525823/pdf/ICR0000422912292017.pdf.

Maidment R I, David IF Grimes, Richard P. Allan, Helen Greatrex, O. Rojas, and O Leo. (2013). Evaluation of satellite-based and model re-analysis rainfall estimates for Uganda. Meteorological Applications, 20(3), pp.308-317.

Maluccio J A, Palermo T, Kadiyala S, and Rawat R. (2015). Improving health-related quality of life among people living with HIV: results from an impact evaluation of a food assistance program in Uganda. PLoS ONE, 10 (8), pp.e0135879.

Maluccio J A, WuRedwan F, Rokon B, Rawat R, and Kadiyala S. (2016). Assessing the Impact of Food Assistance on Stigma Among People Living with HIV in Uganda Using the HIV/AIDS Stigma Instrument-PLWA (HASI-P). AIDS and Behavior, 21(3), pp.766-782.

Mande N, Gakwaya A M, Byanyima R K, and Othieno E. (2004). The triple assessment in the pre-operative evaluation of patients with breast cancer in Mulago Hospital, Kampala Uganda. East and Central African Journal of Surgery, 9(2), pp.111-116.

Marcella C, Marina D A, and Montalbano P. (2013). The Gender Impact of Microfinance: The Case of Wekembe in Uganda. Brussels: Centre Emile Bernheim, pp.39. Available at: file:///Users/user/Downloads/wp13045.pdf.

Marguerita A L, Kasirye R, Scott C W, and Rotheram B M.J. (2007). Efficacy of a culturally adapted intervention for youth living with HIV in Uganda. Prevention science: the official journal of the Society for Prevention Research, 8(4), pp.271-273.

Matheson A, Scott C, Thomson A, Wyatt A, and Riddell R. (2008). Independent Evaluation of Uganda's Poverty Eradication Action Plan (PEAP). Kampala: Office of the Prime Minister, pp.380. Available at: https://library.oapen.org/bitstream/id/71a1bfae-c60842a7-9142-5b26ae6bd396/340016.pdf.

Matovu E, Mugasa CM, Ekangu RA, Deborggraeve S, Lubega GW, and Laurent T. (2010). Phase II Evaluation of Sensitivity and Specificity of PCR and NASBA Followed by 
Oligochromatography for Diagnosis of Human African Trypanosomiasis in Clinical Samples from D.R. Congo and Uganda. Plos Neglected tropical diseases, 4(7), pp.e737.

Matovu J M, Bbaale E, Wasswa F, and Oryema J B. (2018). Harnessing Uganda's Demographic Dividend: Evidence from National Transfer Accounts. Kampala: The National Population Council (NPC), pp.44. Available at: http://npcsec.go.ug/wpcontent/uploads/2013/06/Harnessing-DD-Evidence-from-NTA.pdf.

Matsumoto T, Yamano T, and Sserunkuuma D. (2013). Technology Adoption and Dissemination in Agriculture: Evidence from Sequential Intervention in Maize Production in Uganda. Tokyo: National Graduate Institute for Policy Studies, pp.59. Available at: https://core.ac.uk/download/pdf/51221422.pdf.

Maundrell F, and Brinn P. (2002). Implementation completion report for Uganda - Cotton Subsector Development Project. Washington, D.C: World Bank, pp.58. Available at: http://documents.worldbank.org/curated/en/920631468318877470/Uganda-CottonSubsector-Development-Project.

Maundrell F, Brinn P, and Evers G. (2005). Project performance assessment report for Uganda - Cotton subsector Development Project and Agricultural Research and Trianing Project. Washington, D.C: World Bank, pp.40. Available at: http://documents1.worldbank.org/curated/en/375301468318016274/pdf/326130rev.p df.

Mbalinda S N, Plover C M, Burnham G, Kaye D, Mwanika A, Oria H, and Groves S. (2011). Assessing community perspectives of the community-based education and service model at Makerere University, Uganda: a qualitative evaluation. BMC International Health and Human Rights, 11(1), pp.s6.

Mbetu R, Kabeberi M J, Adupa R, and Jurua A. (2004). Uganda District Development Project Pilot Phase II, UGA/01/C01. New York: United Nations Development Programme, pp.119. Available at: https://erc.undp.org/evaluation/documents/detail/290.

Mbonye A K, Bygbjerg I, and Magnussen P. (2007). Intermittent preventive treatment of malaria in pregnancy: Evaluation of a new delivery approach and the policy implications for malaria control in Uganda. Health Policy, 81(2-3), pp.228-241.

Mbonye A K, Clarke S E, Lal S, Clare I C, Hutchinson E, Kristian S Hansen K.S, and Magnussen P. (2015). Introducing rapid diagnostic tests for malaria into registered drug shops in Uganda: lessons learned and policy implications. Malaria Journal, 14(1), pp.448.

Mbonye M K, Burnett S M, Burua A, Colebunders R, Crozier I, Kinoti S N, Ronald A, Naikoba S, Rubashembusya T, Van Geertruyden J P, Willis K S, and Weaver M R. (2014). Effect of Integrated Capacity-Building Interventions on Malaria Case Management by Health Professionals in Uganda: A Mixed Design Study with Pre/Post and Cluster Randomized Trial Components. PLOS ONE, 9 (1), pp.e84945.

Mbulaiteye S M, Reeves B C, Karabalinde A, Ruberantwari A, Mulwanyi F, Whitworth J A. G, and Johnson G J. (2002). Evaluation of E-optotypes as a screening test and the 
prevalence and causes of visual loss in a rural population in SW Uganda. Ophthalmic Epidemiology, 9(4), pp.251-262.

McNiven S, Gilligan D O, and Hotz C. (2015). Sustainability of Impact: Dimensions Of Decline And Persistence in Adoption of a Biofortified Crop in Uganda. New Delhi: International Initiative for Impact Evaluation (3ie), pp.62. Available at:

http://www.3ieimpact.org/sites/default/files/2019-01/ie35-uganda-biofortifiedsweetpotato-crop_0.pdf.

Mercy Corps. (2011). Building bridges to peace: final evaluation report. Washington, D.C: USAID, pp.53. Available at: https://pdf.usaid.gov/pdf_docs/PBAAE651.pdf.

Mercy-Corps. (2019). Endline Assessment for Multi-Sectoral Assistance to South Sudanese Refugees and Ugandan Host Communities in Bidibidi, Palorinya and Rhino Camp. Portland: Mercy corps, pp.100. Available at:

https://www.careevaluations.org/evaluation/endline-assessment-for-multi-sectoralassistance-to-south-sudanese-refugees-and-ugandan-host-communities-in-bidibidipalorinya-and-rhino-camp/.

Meredith J, Robinson J, Walker S, and Wydick B. (2013). Keeping the doctor away:

Experimental evidence on investment in preventative health products. Journal of Development Economics, 105, pp.196-210.

Mermin J, Ekwaru J P, Were W, Degerman R, Bunnell R, Kaharuza F, Downing R, Coutinho A, Solberg P, Alexander L N, Tappero J, Campbell J, and Moor D M. (2011). Utility of routine viral load, CD4 cell count, and clinical monitoring among adults with HIV receiving antiretroviral therapy in Uganda: randomised trial. BMJ, 343, pp.d6792.

Metzler J, R Kaijuka M. Vojta, K. Savage, M. Yamano, A. Schafer, G. Yu, and A. Ager. (2013). Evaluation of Child Friendly Spaces: Uganda Field Study Summary Report. Uxbridge: World Vision, pp.18. Available at: https://www.wvi.org/sites/default/files/WV\%20Uganda\%20CFS\%20Field\%20Study_Rep ort.pdf.

Meyer A J, Babirye D, Hough M M, Mark D Ayakaka I, and Lucian D. (2018). Text Messages Sent to Household Tuberculosis Contacts in Kampala, Uganda: Process Evaluation. JMIR mHealth and uHealth, 6(11), pp.e10239.

Migliorisi S. (2014). Project Performance Assessment Report for Uganda-Second Local Government Development Project. Washington, D.C: World Bank, pp.62. Available at: http://documents.worldbank.org/curated/en/278231468318580765/Uganda-SecondLocal-Government-Development-Project-LGDP-II.

Mijumbi D R, and Sewankambo N K. (2017). A Process Evaluation to Assess Contextual Factors Associated with the Uptake of a Rapid Response Service to Support Health Systems' Decision-Making in Uganda. International Journal of Health Policy and Management, 6(10), pp.561.

Millard A, Enemark U, and Kandyomunda B. (2018). Evaluation of Health Guarantee to Centenary Rural Development Bank in Uganda. Stockholm: SIDA, pp.108. Available at: 
https://www.sida.se/contentassets/3af55385d03c4da295bd3565fbf535c8/de2018_26_ 62177en.pdf.

Miller J S, Musominali S, Baganizi M, and Paccione G A. (2014). A process evaluation of performance-based incentives for village health workers in Kisoro district, Uganda. Human Resources for Health, 12(1), pp.19.

Mills E J, Bakanda C, Birungi J, Chan K, Ford N, Cooper C L, and Hogg R S. (2011). Life Expectancy of Persons Receiving Combination Antiretroviral Therapy in Low-Income Countries: A Cohort Analysis from Uganda. Annals of internal medicine, 155(4), pp.209216.

Mills S L. (2012). Implementation Completion and Results Report for Uganda-Reproductive Health Vouchers in Western Uganda. Washington, D.C: World Bank, pp.53. Available at: http://documents1.worldbank.org/curated/en/898221468113336731/pdf/955690ICR0 OPUBOrs0inOWesternOUganda.pdf.

Ministry of Health, Health Systems 20, 20, and Makerere University School of Public Health. (2012). Uganda Health System assessment 2011. Washington, D.C: USAID, pp.181. Available at: https://www.hfgproject.org/wpcontent/uploads/2015/02/Uganda_HSA_2011.pdf.

Ministry of Health, and Macro International Inc. (2008). Uganda Service Provision Assessment Survey 2007. Washington, D.C: USAID, pp.743. Available at: https://www.google.com/url?sa=t\&rct=j\&q=\&esrc=s\&source=web\&cd=112\&ved=2ahU KEwilyJS7mtrlAhWNDewKHcnhACY4bhAWMAF6BAgEEAI\&url=https\%3A\%2F\%2Fdhspro gram.com\%2Fpubs\%2Fpdf\%2FSPA13\%2FSPA13.pdf\&usg=AOvVaw3Mk6YyFznlwp_gbja o_Yg7.

Miovic P. (2005). Implementation completion report for Uganda - Third Poverty Reduction Support Credit. Washington, D.C: World Bank, pp.110. Available at: http://documents1.worldbank.org/curated/en/943481468760754804/pdf/28838.pdf.

Miovic P, and Siddiky A E. (2006). Implementation completion report for Uganda - Fourth Poverty Reduction Support Operation Project. Washington, D.C: World Bank, pp.55. Available at: http://documents1.worldbank.org/curated/en/358281468311073770/pdf/35569.pdf.

Mitchell K, Nakamanya S, Kamali A, and Whitworth J A. (2002). Exploring the Community Response to a Randomized Controlled HIV/AIDS Intervention Trial in Rural Uganda. AIDS Education and Prevention, 14(3), pp.207-216.

Mitchell K, Nakamanya S, Kamali A, and Whitworth J A. (2001). Community-based HIV/AIDS education in rural Uganda: which channel is most effective? Health Education Research, 16(4), pp.411-423.

Mitzie A D, Gray R H, Grabowski M K, Serwadda D, Kigozi G, Gravitt P E, Nalugoda F, Watya S, Wawer M J, Quinn T C, and Tobian A A R. (2013). Male circumcision decreases high-risk human papillomavirus viral load in female partners: A randomized trial in Rakai, Uganda. International Journal of Cancer banner, 133(5), pp.1247-1252. 
Mpyisi E, Nuwagira A, Isooba D, and Azuba R. (2012). Uganda - National Livestock Productivity Improvement Project (NLPIP) - Project Completion Report (PCR). Abidjan: African Developement Bank, pp.27. Available at:

https://www.afdb.org/fileadmin/uploads/afdb/Documents/Project-and-

Operations/Uganda_-

_National_Livestock_Productivity_Improvement_Project_NLPIP_-

_Project_Completion_Report_PCR_pdf.

Mubiru D, Byabasheija R, Bwanika J B, Meier J E, Magumba G, Kaggwa F M, Abusu J O, Opio A C, Lodda C C, Patel J, and Diaz T. (2015). Evaluation of Integrated Community Case Management in eight districts of Central Uganda. PLoS ONE, 10(8), pp.e0134767e0134767.

Mubuuke A G, Kiguli-Malwadde E, Byanyima R, and Businge F. (2008). Evaluation of community-based education and service courses for undergraduate radiography students at Makerere University, Uganda. Rural Remote Health, 8(4), pp.976.

Mugisha A R. (2002). Evaluation of Community-Based Conservation Approaches: Management of Protected Areas in Uganda.

Mukisa I. (2016). Uganda's Second Competitiveness and Investment Climate Strategy (CICSII). Kampala: Office of the Prime Minister, pp.305. Available at: F:IUG AGMIMPS-1617Trade-Industry-and-Cooperatives.pdf.

Müller R, Drotbohm H, and Bisasso F. (2003). Summary of the Evaluation "Combating Youth Poverty - partial study Uganda". Bonn: German Development Cooperation, pp.5. Available at: http://www.oecd.org/countries/tuvalu/36738267.pdf.

Munyegera G K, and Matsumoto T. (2016). Mobile Money, Remittances, and Household Welfare: Panel Evidence from Rural Uganda. World Development, 79, pp.127-137.

Muriel V, Driscoll Z, Lister S, and Opio D. (2015). Irish Aid Country Strategy Paper Uganda, 2010-2014. Oxford: Mokoro Ltd, pp.140. Available at: http://www.oecd.org/derec/ireland/ireland_UgandaCSP_FinalReport.pdf.

Muriel V, Driscoll Z, Lister S, and Opio D. (2015). Evaluation of Irish Aid's Uganda Country Strategy Programme 2010-2014. Oxford: Mokoro, pp.140. Available at: https://www.irishaid.ie/media/irishaid/allwebsitemedia/30whatwedo/IA_UgandaCSP_Fi nalReport_Final_05-05-2015.pdf.

Muthui V N, and Wasige j. (2016). Strengthening Climate Information and Early Warning Systems (SCIEWS) Project - Uganda. New York: United Nations Development Programme (UNDP), pp.66. Available at: https://erc.undp.org/evaluation/documents/detail/9813.

Mutunga W M, Reiter W, and Siebel W. (2003). Evaluation of International Law Institute in Uganda. Vienna: Austrian Development Cooperation, pp.2. Available at: http://www.oecd.org/countries/uganda/35131420.pdf.

Mutyaba I, Phipps W, Krantz E M, Goldman J D, Nambooze S, Orem J, and Casper C. (2015). A Population-Level Evaluation of the Effect of Antiretroviral Therapy on Cancer Incidence 
in Kyadondo County, Uganda, 1999 - 2008. J Acquir Immune Defic Syndr, 69(4), pp.4816.

Mutyaba T, Mirembe F S, and Weiderpass E. (2010). Evaluation of 'see-see and treat' strategy and role of HIV on cervical cancer prevention in Uganda. Reproductive Health, $7(1)$, pp.4.

Muwanga A, Tumusiime A, and Isamat P. (2018). Environmental and social impact assessment for the proposed 33kv distribution lines in the districts of Masaka, Gomba, Butambala, Mukono and Luwero (package 2, lot 4, 5 \& 6). Washington, D.C: World bank, pp.266. Available at: http://rea.or.ug/resources/Package\%20B.pdf.

Muwanga F S.J. (2011). Energy for Rural Transformation Impact Assessment of ERT 1. Kampala: Ministry of Finance, Planning and Economic Development, pp.28. Available at: http://www.oag.go.ug/wp-content/uploads/2015/12/ENERGY-FOR-RURALTRANSFORMATION-ERT-PCU-II-REPORT-OF-THE-AUDITOR-GENERAL-2014.pdf.

Muzaki S, Tushabomwe D, Bewayo C, and Kitutu D. (2013). Final Evaluation of the Youth Empowerment Project in Karamoja. New York: UNITED NATIONS DEVELOPMENT PROGRAMME (UNDP), pp.47. Available at: https://erc.undp.org/evaluation/documents/download/8106.

Nabirye J, Nampala P, Ogenga-Latigo M W, Kyamanywa S, Wilson H, Odeke V, and Adipala E. (2003). Farmer-participatory evaluation of cowpea integrated pest management (IPM) technologies in Eastern Uganda. Crop Protection, 22(1), pp.31-38.

Nabunya P, Ssewamala F M, and Ilicc V. (2014). Family economic strengthening and parenting stress among caregivers of AIDS-orphaned children: Results from a cluster randomized clinical trial in Uganda. Children and Youth Services Review, 44, pp.417421.

Nabunya P, Ssewamala F M, Mukasa M N, Byansi W, and Nattabi J. (2015). Peer mentorship program on HIVIAIDS knowledge, beliefs, and prevention attitudes among orphaned adolescents: An evidence- based practice. Vulnerable Children and Youth Studies, 10(4), pp.345-356.

Nahamya P A, Bagamba F, Mgenzi S R,B, Edmeades S, Kalyebara R, Karamura D, Katungi E, Mutebi E K, Nkulaba M J, Smale M, Tushemereirwe W K, and Stanley W. (2007). An Economic Assessment of Banana Genetic Improvement and Innovation in the lake victoria region of Uganda and Tanzania. Washington, D.C: International Food Policy Research Institute (IFPRI), pp.155. Available at: https://ideas.repec.org/p/fpr/resrep/155.html.

Najjumba I M, and Marshall J H. (2013). Improving Learning in Uganda Vol. II Problematic Curriculum Areas and Teacher Effectiveness: Insights from National Assessments. Washington, D.C: World Bank, pp.171. Available at: https://learningportal.iiep.unesco.org/en/library/improving-learning-in-ugandavolume-ii-problematic-curriculum-areas-and-teacher. 
Nakanjako D, Katamba A, Kaye D K, Okello E, Kamya M R, Sewankambo N, and MayanjaKizza H. (2014). Doctoral training in Uganda: evaluation of mentoring best practices at Makerere university college of health sciences. BMC Medical Education, 14(1), pp.9.

Nakimuli M E, Wamala K, Okello J, Alderman S, and Odokonyero R. (2015). Group support psychotherapy for depression treatment in people with HIV/AIDS in northern Uganda: a single-centre randomised controlled trial. The Lancet, 2(5), pp.e190-199.

Namanya B, and Akello E. (2010). Evaluation of UNDEF-Funded: Grassroots Women Leaders in Democracy Project (UGA00055848/UDF-UGA-06-119). New York: United Nations Development Programme (UNDP), pp.69. Available at: https://erc.undp.org/evaluation/documents/detail/4153.

Namanya B, and Akello E. (2010). Evaluation of UNDEF-Funded: Human Rights and Fundamental Freedoms Awareness Project (UGA00055848/UDF-UGA-06-120). New York: United Nations Development Programme (UNDP), pp.69. Available at: https://erc.undp.org/evaluation/documents/detail/4157.

Namanya B, and Kiiza G M. (2013). End of Project Evaluation of Civic and Political Participation of Women and Youth Projects. New York: United Nations Development Programme (UNDP), pp.74. Available at:

https://erc.undp.org/evaluation/evaluations/detail/5541.

Nambusi K, Tanya A, Devries K M, Lori, Nakuti J, Starmann E, Musuya T, Heise L, and Watts C. (2015). What is the potential for interventions designed to prevent violence against women to reduce children's exposure to violence? Findings from the SASA! study, Kampala, Uganda. Child Abuse Neglect, 50, pp.128-140.

Nambusi K, Tanya A, Devries K M, Starmann E, Michau L, Nakuti J, Musuya T, Heise L, and Watts C. (2014). The impact of SASA!, a community mobilization intervention,on reported HIV-related risk behaviours and relationshipdynamics in Kampala, Uganda. Journal of the International AIDS Society, 17(1), pp.19232-19232.

Nankabirwa V, Tylleskar T, Nankunda J, Ingunn M S, and Tumwine J K. (2011). Malaria parasitaemia among infants and its association with breastfeeding peer counselling and vitamin A supplementation: a secondary analysis of a cluster randomized trial. PLOS ONE, 6(7), pp.e21862.

Nannyonjo H, and Áine H. (2007). Education Inputs in Uganda - An Analysis of Factors Influencing Learning Achievement in Grade Six. Washington, D.C: World Bank - Africa Region Human Development Department, pp.110. Available at: http://documents.worldbank.org/curated/en/445131468310730593/Education-inputsIn-Uganda-an-analysis-of-factors-influencing-learning-achievement-in-grade-six.

Nanyonjo A, Ssekitooleko J, Counihan H, Makumbi F, and Tomson G. (2015). Impact of an integrated community case management programme on uptake of appropriate diarrhoea and pneumonia treatments in Uganda: a propensity score matching and equity analysis study. International Journal for Equity in Health, 14, pp.74. 
Nayiga S, DiLiberto D, Taaka L, Nabirye C, Haaland A, Staedke S G, and Chandler C I.R. (2014). Strengthening patient-centred communication in rural Ugandan health centres: A theory-driven evaluation within a cluster randomized trial. Evaluation (Lond), 20(4), pp.471-491.

Ndandiko C. (2006). Public-Private Partnership (PPP) - Country Study Uganda. In: International public procurement conference: pp.18. Available at: http://ippa.org/images/PROCEEDINGS/IPPC2/Article_26_Charles.pdf.

Ndibazza J, Mpairwe H, Webb E L, Mawa P A, Nampijja M, Muhangi L, Kihembo M, Lule S A, Rutebarika D, Apule B, Akello F, Akurut H, Oduru G, Naniima P, Kizito D, Kizza M, Kizindo R, Tweyongere R, Alcock K J, Muwanga M, and Elliott A M. (2012). Impact of Anthelminthic Treatment in Pregnancy and Childhood on Immunisations, Infections and Eczema in Childhood: A Randomised Controlled Trial. PLOS ONE, 7(12), pp.e50325.

Ndlovu L B, and Musoke R A. (2008). Terminal Evaluation of The Pilot Business Linkages Programme for UNDP Uganda. New York: United Nations Development Programme, pp.74. Available at: https://erc.undp.org/evaluation/documents/detail/1996.

Ndyomugyenyi R, Clarke S E, Hutchison C L, Hansen K S, and Magnussen P. (2011). Efficacy of malaria prevention during pregnancy in an area of low and unstable transmission: an individually-randomised placebo-controlled trial using intermittent preventive treatment and insecticide-treated nets in the Kabale Highlands, southwestern Uganda. Transactions of The Royal Society of Tropical Medicine and Hygiene, 105(11), pp.607616.

Neuner F, Onyut P L, Ertl V, Odenwald M, Schauer E, and Elbert T. (2008). Treatment of posttraumatic stress disorder by trained lay counselors in an African refugee settlement: A randomized controlled trial. Journal of Consulting and Clinical Psychology, 76(4), pp.686-694.

Neuner F, Schauer M, Klaschik C, Karunakara U, and Elbert T. (2004). A Comparison of Narrative Exposure Therapy, Supportive Counseling, and Psychoeducation for Treating Posttraumatic Stress Disorder in an African Refugee Settlement. Journal of Consulting and Clinical Psychology, 72(4), pp.579-587.

Ngonidzaishe M, Ahikire J, and Chisvo M. (2015). Final Evaluation of the United Nations Joint Programme for Gender Equality in Uganda. New York: United Nations Development Programme, pp.109. Available at: https://erc.undp.org/evaluation/documents/detail/8769.

Nguyen S N. (2007). Implementation Completion and Results Report for Uganda-HIV/AIDs Control Project. Washington, D.C: World Bank, pp.59. Available at: http://documents.worldbank.org/curated/en/116241468316988721/Uganda-HIV-AIDSControl-Project.

Nikkari S. (2015). Global health security agenda pilot assessment of Uganda. Oklahoma: Global health security Agenda, pp.34. Available at: https://www.ghsagenda.org/docs/default-source/jee-reports/uganda-jee-report.pdf. 
Njoroge K P, Tomicic M, Matovu J M, and Kyalimpa D. (2014). Evaluation of Country Programme Action Plan Outcomes (2010-2015). New York: United Nations Development Programme, pp.63. Available at: https://erc.undp.org/evaluation/documents/detail/8514.

NORC at the University of Chicago. (2017). Performance \& impact evaluation (P\&E) of the USAID/Uganda school health and reading program: result 1 school level interventions: impact evaluation final report. Washington, D.C: USAID, pp.248. Available at: https://pdf.usaid.gov/pdf_docs/PBAAH456.pdf.

NORC at the University of Chicago. (2016). Performance \& impact evaluation (P\&IE): final performance evaluation: school health and reading program (SHRP). Washington, D.C: USAID, pp.60. Available at: https://pdf.usaid.gov/pdf_docs/PBAAH455.pdf.

Norway F. (2018). Report of the Evaluation of the Women's Economic Participation and Rights Programme in Uganda. Oslo:Norad: Norad, pp.56. Available at: https://norad.no/globalassets/publikasjoner/publikasjoner-2018/ngoevalueringer/report-of-the-evaluation-of-the-womens-economic-participation-andrights-programme-in-uganda-.pdf.

Nsabagasani X, Käll, er K, Peterson S, Pariyo G, and Tomson G. (2007). Home-based management of fever in rural Uganda: community perceptions and provider opinions. Malaria Journal, 6(11), pp.1-8.

Nuwagaba A, Sentumbwe S, Rwangoga C, and Bamuhiiga S R. (2013). Final evaluation of the health initiatives for the private sector (HIPS) project, August 2012-January 2013. Washington, D.C: USAID, pp.100. Available at: https://pdf.usaid.gov/pdf_docs/PDACU928.pdf.

Nuwagira A, Meng J M, and Loulseged M. (2018). Community Agricultural Infrastructure Improvement Programme - Project 3 (CAIIP-3). Abidjan: African Development Bank, pp.17. Available at: https://www.afdb.org/fileadmin/uploads/afdb/Documents/BoardsDocuments/PCR-_UGANDRA-

Community_Agricultural_Infrastructure_Improvement_Programme_Project_3_CAIIP3.pdf.

NUWAGIRA A, OSAN, Mugisha J, and Azuba R. (2012). Uganda - Creation of Sustainable Tsetse and Trypanosomiasis Free Areas in East and West Africa - Project Completion Report (PCR). Abidjan: African Development Bank, pp.28. Available at: https://www.afdb.org/fileadmin/uploads/afdb/Documents/Project-andOperations/Uganda\%20\%20Creation\%20of\%20Sustainable\%20Tsetse\%20and\%20Trypanosomiasis\%20Free\%2 OAreas\%20in\%20East\%20and\%20West\%20Africa\%20\%20Project\%20Completion\%20Report\%20\%28PCR\%29.pdf.

Nuwakora C B, and Nimusiima D. (2018). Terminal Evaluation of Peace Architecture for Conflict Transformation Framework Project. New York: UNDP, pp.67. Available at: https://erc.undp.org/evaluation/documents/detail/11961. 
Nuwakora C B, and Nimusiima D. (2017). Inclusive and Sustainable New Communities Project in Uganda Mid-Term Evaluation. New York: United Nations Development Programme, pp.97. Available at:

https://erc.undp.org/evaluation/documents/detail/10683.

O'Donnell D, Whitehead A, and Kanyana R. (2017). An assessment of the compatibilty of Ugandan legislation with the convention on the rights of the child. Kampala: Uganda Human Rights Commission, pp.96. Available at:

https://www.google.com/url?sa=t\&rct=j\&q=\&esrc=s\&source=web\&cd=1\&ved=2ahUKE wizq_CgwYHmAhXmsaQKHdhSDV0QFjAAegQIBBAC\&url=https\%3A\%2F\%2Fwww.unicef .org\%2Fuganda\%2Fmedia\%2F2691\%2Ffile\%2FAn\%2520Assessment\%2520of\%2520the \%2520Compatibility\%2520of\%2520Ugandan\%2520Legislation\%2520with\%2520the\%2 520Convention\%2520on\%2520the\%2520Rights\%2520of\%2520the\%2520Child\%2520( Main\%2520report).pdf\&usg=AOvVaw1NjA7Xh9exwlyhpyvcyT9A.

Obare F, Okwero P, Villegas L, Mills S, and Bellows B. (2016). Increased Coverage of Maternal Health Services among the Poor in Western Uganda in an Output-Based Aid Voucher Scheme. Washington, D.C: World Bank, pp.46. Available at: http://documents.worldbank.org/curated/en/349851468195547904/pdf/WPS7709.pdf.

Ocaya L V, and Asebe E. (2004). Implementation completion report for Uganda - El Nino Emergency Road Repair Project. Washington, D.C: World Bank, pp.33. Available at: http://documents1.worldbank.org/curated/en/945061468346737543/pdf/29653.pdf.

Ocira L. (2011). Mid-Term Evaluation Report of Northern Uganda Early Recovery Project 2010-2011. New York: United Nations Development Program, pp.111. Available at: https://erc.undp.org/evaluation/documents/detail/5228.

Odongo-A E I, Lakwo T L, and Doehring M E. (2010). Evaluation of Schistosoma mansoni morbidity one year after praiquantel treatment in rhino camp and Obongi in West Nile, Uganda. African journal of infectious diseases, 4(2), pp.43-50.

Oduol J B A, Binam J N, Olarinde L, Diagne A, and Adekunle A A. (2011). Impact of adoption of soil and water conservation technologies on technical efficiency: insight from smallholder farmers in Sub-Saharan Africa. Journal of Development and Agricultural EcoNomics, pp.655-669.

Office of the Prime Minister, and Uganda. (2012). Evaluation of the Effectiveness of Government of Uganda's Response to Curb Absenteeism in the Public Service. Kampala: Office of Prime Minister, Uganda, pp.59.

Ofwono N, Chisvo M, Bategeka L, Muwanga S N, and Katagyira A. (2011). Evaluation of the Implementation of the Paris Declaration in Uganda - Phase 2. Vienna: Austrian Development Agency, pp.146. Available at: http://www.oecd.org/countries/uganda/48695415.pdf.

Ogal N, Katuramu G, Engwau D, and Kagoro G. (2018). Water Supply and Sanitation Program (WSSP I). Abidjan: African Development Bank, pp.37. Available at: https://www.afdb.org/fileadmin/uploads/afdb/Documents/Project-andOperations/Uganda.PCR.Water_Supply_and_Sanitation_Programme_I_WSSP_I_En.pdf. 
Ohno I. (2018). Country Assistance Evaluation of the Republic of Uganda. Tokyo: Ministry of Foreign Affairs of Japan, pp.38. Available at: https://www.mofa.go.jp/policy/oda/evaluation/FY2017/pdfs/uganda.pdf.

Okaalet P, Olsen N, Irungu S, Mwangi J, Wamanya D, and Serwanja C. (2013). Evaluation report: USAID/Uganda faith-based HIV and AIDS program. Washington, D.C: USAID, pp.101. Available at: https://pdf.usaid.gov/pdf_docs/PA00K66J.pdf.

Okech A, Carr-Hill R A, Katahoire A R, Kakooza T, Ndidde A N, and Oxenham J. (2001). Adult Literacy Programs in Uganda - World Bank. Washington, D.C: Minister of Gender, Labour and Social Development, World Bank, pp.148. Available at: https://openknowledge.worldbank.org/handle/10986/13856.

Okello F. (2018). Endline Evaluation of Integrated Emergency Response Program for South Sudanese Refugees and affected host community members Program in IMPEVI Settlement, Arua District. Geneva: CARE, pp.24. Available at: https://www.careevaluations.org/evaluation/endline-integrated-emergency-responseimpevi-settlement-uganda/.

Okello F, Odokonyero J, and Odwong F. (2018). Evaluation of Lifesaving Shelter, Protection and Health Support for South Sudanese Refugees in Uganda Rhino Extension Omugo, Arua District. Geneva: CARE, pp.69. Available at: https://www.careevaluations.org/evaluation/evaluation-of-lifesaving-shelterprotection-and-health-support-for-south-sudanese-refugees-in-uganda-rhinoextension-omugo-arua-district/.

Okello W O, Muhanguzi D, MacLeod E T, Welburn S C, Waiswa C, and Shaw A P. (2015). Contribution of draft cattle to rural livelihoods in a district of southeastern Uganda endemic for bovine parasitic diseases: an economic evaluation. Parasites \& Vectors, 8(1), pp.571.

Olaa M O. (2007). Implementation completion and results report for Uganda - Second Economic and Financial Management Project. Washington, D.C: World Bank, pp.62. Available at:

http://documents.worldbank.org/curated/en/909551468117886385/Uganda-SecondEconomic-and-Financial-Management-Project.

Olaa M O, and Mehta B E. (2008). Implementation Completion and Results Report for Uganda - Second Local Government Development Project. Washington, D.C: World Bank, pp.55. Available at:

http://documents1.worldbank.org/curated/en/163731468346741209/pdf/ICR7620ICR0 P071sclosed0July02802008.pdf.

Onestini M, and Nabanyumya R. (2017). Addressing Barriers to Adoption of Improved Charcoal Production Technologies and Sustainable Land Management Practices through an Integrated Approach. New York: United Nations Development Programme, pp.103. Available at: https://erc.undp.org/evaluation/documents/detail/10535.

Operation Evaluation Department. (2006). Uganda - Joint Assistance Strategy - Review of the Harmonization Process in five Countries. Abidjan: African Development Bank, pp.79. 
Available at: https://www.afdb.org/en/documents/document/uganda-joint-assistancestrategy-review-of-the-harmonization-process-in-five-countries-9358/.

Operation Evaluation Department. (2002). 2001-2004 - Uganda - Review of the Bank Group Assistance to the Agriculture and Rural Development Sector Detailed Technical Analysis of Study Key Findings Report. Abidjan: African Development Bank, pp.138. Available at: https://www.afdb.org/en/documents/document/2001-2004-ugandareview-of-the-bank-group-assistance-to-the-agriculture-and-rural-development-sectordetailed-technical-analysis-of-study-key-findings-report-9230.

Operations Evaluation Department. (2000). Uganda - Five Urban Centers Water Supply and Sewerage Rehabilitation Project - PAPER. Abidjan: African Development Bank, pp.48. Available at: https://www.afdb.org/fileadmin/uploads/afdb/Documents/EvaluationReports-_Shared-With-OPEV_/05188234-EN-UGANDA-5-URBAN-CENTERS-WATERSUPPLY-AND-SEWE.PDF.

Operations Evaluation Department. (2004). Uganda Country Assistance Evaluation 1996 2001: African Development Bank. Available at: https://www.afdb.org/sites/default/files/documents/evaluation-reports/00158073-enuganda-cae.pdf.

Operations Evaluation Department. (2001). Uganda Poverty Alleviation Project. Abidjan: African Development Bank, pp.50. Available at: https://www.afdb.org/fileadmin/uploads/afdb/Documents/Evaluation-Reports_Shared-With-OPEV_/00702710-EN-UGANDA-POVERTY-ALLEVIATION-PROJECTPPER.PDF.

Oriana B, iera, Niklas Buehren, Robin Burgess, Markus Goldstein, Selim Gulesci, Imran Rasul, and Munshi Sulaiman. (2013). Empowering adolescent girls: evidence from a randomized control trial in Uganda. Washington, D.C: World Bank, pp.2. Available at: http://documents.worldbank.org/curated/en/427711468175785983/pdf/813130BRIOE mpo00Box379819B00PUBLIC0.pdf.

Orth M, Birsan M, and Gotz G. (2018). The Future of Integrated Policy-Based Development Cooperation. Lessons from the Exit from General Budget Support in Malawi, Rwanda, Uganda and Zambia. Bonn: German Institute for Development Evaluation (DEval), pp.190. Available at: http://www.oecd.org/derec/germany/Future-Integrated-PolicyBased-Development-Cooperation.pdf.

Osborn G, and Mullins J. (2010). Uganda health cooperative child survival project, Bushenyi District, Uganda: September 30, 2005 to September 29, 2010 -- final evaluation report. Washington, D.C: USAID, pp.151. Available at: https://pdf.usaid.gov/pdf_docs/PDACR842.pdf.

Osur J, Baird T L, Levandowski B A, Jackson E Murokora, and D. (2013). Implementation of misoprostol for postabortion care in Kenya and Uganda: a qualitative evaluation. Global Health Action, 6(1), pp.19649.

Othieno A. (2014). Project on Promoting Chemical Safety for Children in Rural Agricultural Communities of Uganda. New York: UNITED NATIONS DEVELOPMENT PROGRAM (GEF) 
SMALL GRANTS PROGRAM - UGANDA, pp.44. Available at: https://erc.undp.org/evaluation/documents/detail/7890.

Øvretveit J, O Amoah A, Kasule K, and Rahimzai M. (2018). Evaluation of a Results-based Financing Intervention in South West Uganda. Washington, D.C: USAID, pp.54. Available at:

https://www.usaidassist.org/sites/default/files/uganda_rbf_evaluation_may2018_ada.pdf

Oxford Policy Management. (2005). Evaluation of the Plan for Modernisation of Agriculture. Oxford: Oxford Policy Management, pp.96. Available at:

http://www.netpublikationer.dk/um/6207/pdf/200506PMAevaluation.pdf.

Oxford Policy Management, Economic Policy Research Centre, Department of Anthropology, Sociology, and University of Makerere. (2015). Evaluation of the Uganda Social Assistance Grants for Empowerment (SAGE) Programme. Kampala: Ministry of Gender Labour and Social Protection, pp.62. Available at: https://assets.publishing.service.gov.uk/government/uploads/system/uploads/attach ment_data/file/607525/Evaluation-of-Uganda-Social-Assistance-Grants-forEmpowerment.pdf.

Parby J I. (2013). Implementation Completion and Results Report for Uganda - Local Government Management and Services Delivery Project. Washington, D.C: World Bank, pp.64. Available at: http://documents.worldbank.org/curated/en/487401468308686548/Uganda-LocalGovernment-Management-and-Services-Delivery-Project.

Paul P, Winkler J L, Bartolini R M, Penny M E, Huong T T, Kumakech E, and Jeronimo J. (2013). Screen-and-Treat Approach to Cervical Cancer Prevention Using Visual Inspection with Acetic Acid and Cryotherapy: Experiences, Perceptions, and Beliefs From Demonstration Projects in Peru, Uganda, and Vietnam. Global health and cancer, 18(12), pp.1278-1284.

Perkins G. (2004). Project performance assessment report for Uganda - Primary Education and Teacher Development Project (Credit 2493), and Education Sector Adjustment Credit (Credit 3049). Washington, D.C: World Bank, pp.54. Available at: http://documents1.worldbank.org/curated/en/756901468760512026/pdf/275380UG.pdf

Petracco C K, and Pender J L. (2009). Evaluating the Impact of Land Tenure and Titling on Access to Credit in Uganda. Toronto: PB - International Association of Agricultural Economists, pp.29. Available at: https://tind-customeragecon.s3.amazonaws.com/7bb5798a-2dd6-4bfc-8313-68355b405883?responsecontent-disposition=attachment\%3B\%20filename\%2A\%3DUTF8\%27\%27IAAE744_2009_Petracco\%2520and\%2520Pender.pdf\&response-contenttype=application\%2Fpdf\&X-Amz-Algorithm=AWS4-HMAC-SHA256\&X-AmzExpires $=86400 \& X-A m z-C r e d e n t i a l=A K I A X L 7 W 7 Q 3 X H X D V D Q Y S \% 2 F 20210211 \% 2 F e u-$ west-1\%2Fs3\%2Faws4_request\&X-Amz-SignedHeaders=host\&X-AmzDate $=20210211$ T100427Z\&X-AmzSignature $=56262 f f d d d f 988 b 61$ bc435ce8f5c4f81ea6ef72aa7887e274afb4f92728. 
Pia R B, Engle P, and Alderman H. (2007). Early Intervention and Caregiving: Evidence from the Uganda Nutrition and Early Child Development Program. Child Health and Education, 1pp. 112-133(2), pp.112-133.

Pierce R, and Gardner A. (2006). ACDI/VOCA: Uganda -- FY 2002-2006 Title II DAP: final evaluation report. Washington, D.C: USAID, pp.71. Available at: https://pdf.usaid.gov/pdf_docs/PDACl106.pdf.

Pieter D-P, Cowley S, Makara S, Nansozi M, Oloya P, and Arineitwe J. (2011). Strengthening multi-party democracy: end of project evaluation report. Washington, D.C: USAID, pp.154. Available at: https://pdf.usaid.gov/pdf_docs/PA00JZJK.pdf.

Planas M A. (2017). Implementation completion and results report for energy for rural transformation project in support of the second phase of the energy for rural transformation program. Washington, D.C: World Bank, pp.77. Available at: http://documents.worldbank.org/curated/en/388691499446501233/pdf/ICR405306232017.pdf.

Pojarski P I. (2016). Implementation Completion and Results Report for A Second Northern Uganda Social Action Fund Project (NUSAF2). Washington, D.C: World bank, pp.62. Available at:

http://documents1.worldbank.org/curated/en/519571473187545154/pdf/ICR0000380 5-final-08312016.pdf.

Pond R, Matovu F, and Kibuuka F. (2013). Report of the evaluation of the USAID/Uganda stop malaria project. Washington, D.C: USAID, pp.83. Available at: https://pdf.usaid.gov/pdf_docs/PA00JM4D.pdf.

Popkin B P, Koestler L, and Jangeyanga P. (2011). Evaluation report of the northern Uganda water supply services project (NUWATER). Washington, D.C: USAID, pp.134. Available at: https://pdf.usaid.gov/pdf_docs/PDACS579.pdf.

Pronyk P M, Muniz M, Nemser B, Somers M A, McClellan L, Palm C A, Huynh U K, Amor Y B, Begashaw B, McArthur J W, Niang A, Sachs Sonia E, Singh P, Teklehaimanot A, and Sachs J D. (2012). The effect of an integrated multisector model for achieving the Millennium Development Goals and improving child survival in rural sub-Saharan Africa: a non-randomised controlled assessment. The Lancet, 379(9832), pp.21792188.

Purdon M, and Lokina R. (2014). Ex-post Evaluation of the additionality of Clean Development Mechanism Afforestation Projects in Tanzania, Uganda and Moldova. London: Centre for climate change economics and policy, pp.63. Available at: http://theredddesk.org/sites/default/files/resources/pdf/wp166-ex-post-evaluation-ofclean-development-mechanism-afforestation.pdf.

Quigley M A, Kamali A, Kinsman J, Kamulegeya I, Nakiyingi M J, Kiwuwa S, Kengeya KJ.F, Carpenter L M, and Whitworth J A.G. (2004). The impact of attending a behavioural intervention on HIV incidence in Masaka, Uganda. AIDS, 18(15), pp.2055-63. 
Radix Management Consulting Limited. (2017). Evaluation of Public Sector Organisations in Uganda. Kampala: Office of the Prime Minister, pp.140. Available at: http://www.radixconsults.com/wp-content/uploads/2017/06/EVALUATION-OF-PUBLICSECTOR-ORGANISATIONS-IN-UGANDA.pdf.

Ramadhan H. (2012). Evaluation of the impact of Amicaall Uganda programme (10years). New York: UNDP, pp.59. Available at: https://app.box.com/s/crivsx7ijkak89o57ytat94bt72soek6.

Rawat R, Faust E, Maluccio J A, and Kadiyala S. (2014). The impact of a food assistance program on nutritional status, disease progression and food security among people living with HIV in Uganda. JAIDS, 66(1), pp.e15-22.

Rechbauer G. (2013). Implementation Completion and Results Report for Uganda-Second Environmental Management and Capacity Building. Washington, D.C: World Bank, pp.98. Available at: http://documents.worldbank.org/curated/en/876451468114257745/Uganda-SecondEnvironmental-Management-and-Capacity-Building-Project.

Reinikka R, and Svensson J. (2010). Working for God? Evidence from A Change in Financing Of Nonprofit Health Care Providers In Uganda3. Journal of the European Economic Association, 8(6), pp.1159-1178.

Reinikka R, and Svensson J. (2007). The Returns from Reducing Corruption: Evidence from Education in Uganda. Development Economics, pp.40.

Reinikka R, and Svensson J. (2005). Fighting corruption to improve schooling: Evidence from a newspaper compaign in Uganda. Journal of the European Economic Association, 3(23), pp.259-267.

Reinikka R, and Svensson J. (2004). The Power of Information: Evidence from a Newspaper Campaign to Reduce Capture. Washington, D.C: The World Bank.

Reynold D, and Karen T R. (2002). Implementation completion report for Uganda - Third Power Project and Supplemental Credit. Washington, D.C: World Bank, pp.54.

Available at:

http://documents1.worldbank.org/curated/en/424641468317662124/pdf/multiOpage. pdf.

Richard J Carroll. (2014). Implementation Completion and Results Report for Uganda Eighth and Ninth Poverty Reduction Credits Project. Washington, D.C: World Bank, pp.58. Available at:

http://documents1.worldbank.org/curated/en/772461468113066085/pdf/ICR29590P1 01230C0disclosed020250140.pdf.

Rijal A, and Dickson L C. (2014). Territorial Approach to Climate Change (TACC) Project for The Mbale Region of Uganda. New York: United Nations Development Programme, pp.141. Available at: https://erc.undp.org/evaluation/documents/detail/8102.

Rijal A, and Wasige J E. (2016). Enabling Environment for SLM to Overcome Land Degradation in the Uganda Cattle Corridor Districts. New York: United Nations 
Development Programme, pp.109. Available at:

https://www.google.com/search?sxsrf=ALeKk02VntNbgqWL76-

ClbNRItWFpxHDKw\%3A1612939249249\&ei=8X8jYNP4Dsma1 fAPtdmzSA\&q=Enabling+

Environment+for+SLM+to+Overcome+Land+Degradation+in+the+Uganda+Cattle+Corr idor+Districts+Dr+Arun+Rijal\%3B+Dr+John+Ejiet+Wasige\%3B\&oq=Enabling+Environm ent+for+SLM+to+Overcome+Land+Degradation+in+the+Uganda+Cattle+Corridor+Dist ricts+Dr+Arun+Rijal\%3B+Dr+John+Ejiet+Wasige\%3B\&gs_Icp=CgZwc3ktYWIQAzIHCCMQ rgIQJ1D8gwRY5IoEYliRBGgCcAB4AIABIgSIAYAHkgEHMy0xLjAuMZgBAKABAaABAqoBB2 d3cy13a.

Rijsdijk L E, Bos A E. R, Ruiter R A. C, Leerlooijer J N, de Haas B, and Schaalma H P. (2011). The World Starts with Me: A multilevel evaluation of a comprehensive sex education programme targeting adolescents in Uganda. BMC Public Health, 11(1), pp.334.

Rinck D, and Ellis S. (2018). Final Performance Evaluation of The Feed the Future Innovation Lab for Collaborative Research on Aquaculture \& Fisheries (Aquafish II). Washington, D.C: USAID, pp.100. Available at: https://pdf.usaid.gov/pdf_docs/PA00TC2S.pdf.

Rippey H, Kadama H, McCauley A, and Namubiru M. (2007). External assessment of the Elizabeth Glaser Pediatric AIDS Foundation call-to-action pilot program. Washington, D.C: USAID, pp.79. Available at: https://pdf.usaid.gov/pdf_docs/PDACL387.pdf.

Roby J L, and Shaw S A. (2008). Evaluation of a Community-Based Orphan Care Program in Uganda. Journal of contemporary social services, pp.119-128.

Roehler D R, Naumann R B, Mutatina B, Nakitto M, Mwanje B, Brondum L, and ... Dellinger A. M. (2014). Using baseline and formative evaluation data to inform the Uganda Helmet Vaccine Initiative. Global Health Promotion, 20(4), pp.37-44.

Ron S. (2010). Assessment of Groundwater Investigations and Borehole Drilling Capacity in Uganda. New York: UNICEF, pp.128. Available at: https://knowledgepoint.org/upfiles/14311010428865177.pdf.

Rotheram B M.J, Lightfoot M, Kasirye R, and Desmond K. (2012). Vocational training with HIV prevention for Ugandan youth. AIDS and behavior, 16(5), pp.1133-1137.

Roy G. (2000). Uganda - Northern Uganda Reconstruction Project. Washington, D.C: World Bank, pp.34. Available at:

http://documents1.worldbank.org/curated/en/843951511188731249/pdf/multipage.pdf.

Ruanne V B, Heidi V R, Tumwesigye E, Brantley J, Baeten J M, Heerden A V, Turyamureeba B, Joseph P, Krows M, Katherine K T, Schaafsma T T, Hughes J P, and Celum C. (2016). Uptake of antiretroviral therapy and male circumcision after community-based HIV testing and strategies for linkage to care versus standard clinic referral: a multisite, open-label, randomised controlled trial in South Africa and Uganda. The Lancet, 3(5), pp. e212-e220.

Rukundo H. (2017). End of Project Evaluation Report: Sexual Reproductive Maternal Child Health Project. Geneva: CARE, pp.98. Available at: 
https://www.careevaluations.org/evaluation/sexual-reproductive-maternal-childhealth-project/.

Sabine C. (2012). Implementation Completion and Results Report for Uganda-Sustainable Management of Mineral Resources Project. Washington, D.C: World Bank, pp.96. Available at:

http://documents1.worldbank.org/curated/en/581061468349822048/pdf/NonAsciiFile Name0.pdf.

Sackey J, and Turay F. (2009). Uganda Country Assistance Evaluation, 2001-2007 - Joint IEG/OPEV Country Assistance Evaluation. Abidjan: African Development Bank, pp.175. Available at: http://www.oecd.org/countries/uganda/42944274.pdf.

Sanders D, and Buckley A. (2009). ILO Small Enterprise Media in Africa. Geneva: ILO, pp.8. Available at: https://www.ilo.org/wcmsp5/groups/public/---ed_mas/--eval/documents/publication/wcms_117995.pdf.

Saravia E, Pawlowska A E, and Fye L. (2000). Uganda - Enterprise Development Project. Washington, D.C: World Bank, pp.54. Available at: http://documents1.worldbank.org/curated/en/366191468341933760/pdf/multipage.pdf.

Scott L, Custers A, and Dolan C. (2017). Digital Sub-Wallets for Increased Financial Empowerment of Women, Final Report. Geneva: CARE, pp.14. Available at: https://www.careevaluations.org/evaluation/digital-sub\%e2\%80\%90wallets-pilotstudy/.

Seiber E, and Miller A R. (2007). Microfinance investments in quality at private clinics in Uganda: a case-control study. BMC Health Serv Res., 7, pp.168.

Seiber E E, and Amara L R. (2007). Microfinance investments in quality at private clinics in Uganda: a case-control study. BMC Health Services Research, 7(1), pp.168.

Semeere A S, Bbaale D S, Castelnuovo B, Kiragga A N, Kigozi J, Muganzi A, Kambugu A, and Coutinho A G. (2016). Assessing the impact of delivering messages through intimate partners to create demand for voluntary medical male circumcision in Uganda. New Delhi: International Initiative for Impact Evaluation (3ie), pp.60. Available at: http://www.3ieimpact.org/sites/default/files/2019-01/ie48-impact-vmmc-uganda.pdf.

Sennoga E, and Chinien S. (2012). Uganda - Institutional Support Project for Good Governance (ISPGG) - Project Completion Report (PCR). Abidjan: African Develoment Bank, pp.21. Available at:

https://www.afdb.org/fileadmin/uploads/afdb/Documents/Project-andOperations/UGANDAINSTITUTIONAL_SUPPORT_PROJECT_FOR_GOOD_GOVERNANCE_ISPGG_-03-092010_pdf.

Sennoga E B, Kabungo A, and Duru U. (2018). Bujagali Interconnection Project, Project Completion Report. Abidjan: African Develoment Bank, pp.24. Available at: 
https://www.afdb.org/fileadmin/uploads/afdb/Documents/BoardsDocuments/Uganda_-_Bujagali_Interconnection_Project.pdf.

Senyonyi R M, Underwood L A, Suarez E, Musisi S, and Grande T L. (2012). Cognitive behavioral therapy group intervention for HIV transmission risk behavior in perinatally infected adolescents. Health, 4, pp.1334-1335.

Serbanescu F, Goldberg H I, Danel I, Wuhib T, Marum L, Obiero W, and Conlon C M. (2017). Rapid reduction of maternal mortality in Uganda and Zambia through the saving mothers, giving life initiative: results of year 1 evaluation. BMC Pregnancy and Childbirth, 17(1), pp.42.

Seth S C. (2009). Implementation Completion and Results Report for Uganda-Second Phase of the Road Development Program. Washington, D.C: World Bank, pp.62. Available at: http://documents.worldbank.org/curated/en/984861468113065536/Uganda-SecondPhase-of-the-Road-Development-Program-Project.

Seth S C. (2008). Implementation Completion and Results Report for Uganda - Road Sector Institutional Support Technical Assistance Project. Washington, D.C: World Bank, pp.60. Available at:

http://documents1.worldbank.org/curated/en/290121468175741421/pdf/ICR6880Box 03341IC010disclosed081251.pdf.

Shumba C, Memiah P, Atukunda R, Imakit R, Mugadu J, and Stafford K. (2012). Continuous quality improvement in AIDSRelief supported HIV treatment clinics in Uganda: an evaluation of "See-Try-Observe- Continue" (STOC) model in patient care. International Journal of Medicine and Public Health, 2(1), pp.26-31.

Sigei C, Odaga J, Mvundura M, Madrid Y, and Clark A D. (2015). Cost-effectiveness of rotavirus vaccination in Kenya and Uganda. j.vaccine, pp.A109-118.

Singla D R, Kumbakumba E, and Aboud F E. (2015). Effects of a parenting intervention to address both maternal psychological wellbeing and child development and growth in rural Uganda: a community-based, cluster randomised trial. The LANCET Global Health, 3, pp.e458-e469.

Sithole E, Dollo F N, and Nyamutoka P. (2005). Review of the Outcomes and Impact of the Local Access to Justice Component: District Development Programme II, Uganda. New York: United Nations Development Programme. Available at: https://erc.undp.org/evaluation/documents/detail/680.

Siu G, Wight D, Namutebi C, Sekiwunga R, Zalwango F, Kasule S, and Seeley J. (2017). Men's Involvement in a Parenting Programme for Reduction of Gender-Based Violence and Child Maltreatment: Formative Evaluation in Uganda. European Journal of Development Research, 29(5), pp.1017-1037.

Slegtenhorst H, Nugteren M, De Haas A, Rien Strootman, Heydenreich M, Luswata P, Serdarevic N, Grettve E, and Schaap B. (2016). Evaluation of Sida's use of guarantees for market development and poverty reduction. Stockholm: Sida, pp.66. Available at: https://www.sida.se/contentassets/a99e846c5eaf48268efb1f99a0de0edf/21668.pdf. 
Sloane E. (2011). Uganda Cash Transfer Impact Evaluation: Livelihoods and Economic Recovery in Northern Uganda. Oxford: Cash Learning Partnership, pp.41. Available at: http://www.cashlearning.org/downloads/resources/evaluations/ACF\%20Uganda\%20C ash\%20Transfer\%20Impact\%20Evaluation\%20Dec\%202011.pdf.

Sobey R, and Mbogga M. (2018). Strengthening Climate Information \& Early Warning Systems in Uganda (SCIEWS). New York: United Nations Development Programme, pp.19. Available at: https://erc.undp.org/evaluation/documents/download/12116.

Socio economic data centre. (2017). Agender Impact Study of the water and Sanitation subsector. Kampala: Ministry of Water and Environment, pp.91. Available at: https://www.google.com/search?client=firefox-be\&q=Agender+Impact+Study+of+the+watehttps://www.mwe.go.ug/sites/default/files/li brary/2017_Gender\%20Impact\%20Study\%20Report\%20for\%20Water\%20and\%20Sanit ation\%20Sub\%20Sector.pdfr+and+Sanitation+sub-sector.

Sohail A. (2010). The Impact of a Quality-improvement Package on Reproductive Health Services Delivered by Private Providers in Uganda. Studies in Family Planning, 41(3), pp.205-215.

Sonderegger R, Rombouts S, Ocen B, and McKeever R S. (2011). Trauma rehabilitation for war-affected persons in northern Uganda: A pilot evaluation of the EMPOWER programme. British Journal of Clinical Psychology, 50(3), pp.234-249.

Spacek L A, Shihab H M, Lutwama F, Summerton J, Mayanja H, Ronald A, and Quinn T C. (2006). Evaluation of a Low-Cost Method, the Guava EasyCD4 Assay, to Enumerate CD4-Positive Lymphocyte Counts in HIV-Infected Patients in the United States and Uganda. Journal of Acquired Immune Deficiency Syndromes, 41(5), pp.607-610.

Spencer H, Masakure O, and Cranfield J. (2011). Do Fresh Produce Exporters in Sub-Saharan Africa Benefit from GlobalGAP Certification? World Development, 39(3), pp.375-386.

Spencer S, Grant A D, Piola P, Tukpo K, Okia M, Garcia M, and Guthmann J P. (2004). Malaria in camps for internally-displaced persons in Uganda: evaluation of an insecticidetreated bednet distribution programme. Transactions of the Royal Society of Tropical Medicine and Hygiene, 98(12), pp.719-727.

Spindler E, and Ojanduru L. (2018). EDEAN proof of concept: final evaluation report: evaluating a peer learning and community theatre intervention to increase fertility awareness and family planning use. Washington, D.C: Institute for Reproductive Health Georgetown University, pp.101. Available at:

https://pdf.usaid.gov/pdf_docs/PA00T89Z.pdf.

Ssali A, Butler L M, Kabatesi D, King R, Namugenyi A, Kamya M R, Mandel J, Chen S Y, and McFarland W. (2005). Traditional Healers for HIVIAIDS Prevention and Family Planning, Kiboga District, Uganda: Evaluation of a Program to Improve Practices. AIDS and Behavior, 9(4), pp.485-493.

Ssemwanga consulting LTD. (2004). Rural economy and agriculture production (REAP): Palenga and Bobi IDP Camps-Gulu District -- final report for the evaluation of REAP I 
and baseline of REAP II. Washington, D.C: USAID, pp.76. Available at: https://pdf.usaid.gov/pdf_docs/PDACG161.pdf.

Ssengooba F, McPake B, and Palmer N. (2012). Why performance-based contracting failed in Uganda-an "open-box" evaluation of a complex health system intervention. Social science \& medicine, 75(2), pp.377-383.

Ssewakiryanga R, Hodge S, Nuwakora C, and Owor E. (2008). UNDP Uganda Democratic Governance Mid-Term Outcome Evaluation. New York: United Nations Development Programme, pp.87. Available at: https://erc.undp.org/evaluation/documents/detail/2336.

Ssewamala F M, Alicea S, Bannon W M, and Ismayilova L. (2008). A novel economic intervention to reduce HIV risks among school-going AIDS orphans in rural Uganda. The Journal of adolescent health: official publication of the Society for Adolescent Medicine, 42(1), pp.102-104.

Ssewamala F M, Han C K, and Neilands T B. (2009). Asset Ownership and Health and Mental Health Functioning Among AIDS-Orphaned Adolescents: Findings from A Randomized Clinical Trial in Rural Uganda. Social Science \& Medicine, 69(2), pp.191-198.

Ssewamala F M, Han C K, Neilands T B, Ismayilova L, and Sperber E. (2010). Effect of economic assets on sexual risk-taking intentions among orphaned adolescents in Uganda. American journal of public health, 100(3), pp.483-488.

Ssewamala F M, and Ismayilova L. (2009). Integrating Children's Savings Accounts in the Care and Support of Orphaned Adolescents in Rural Uganda. The Social Service Review, 83(3), pp.453-472.

Ssewamala F M, Ismayilova L, McKay M, Sperber E, Bannon W, and Alicea S. (2010). Gender and the Effects of an Economic Empowerment Program on Attitudes Toward Sexual Risk-Taking Among AIDS-Orphaned Adolescent Youth in Uganda. Journal of Adolescent Health, 46(4), pp.372-378.

Ssewamala F M, Karimli L, Torsten N, Huahwang J S, Chang K H, llic V, and Nabunya P. (2016). Applying A Family-Level Economic Strengthening Intervention to Improve Education and Health-Related Outcomes Of School-Going Aids-Orphaned Children: Lessons From A Randomized Experiment In Southern Uganda. Prevention Science, 17 (1), pp.134-143.

Ssewamala F M, Neilands T B, Waldfogel J, and Ismayilova L. (2012). The impact of a comprehensive microfinance intervention on depression levels of AIDS-orphaned children in Uganda. The Journal of adolescent health: official publication of the Society for Adolescent Medicine, 50(4), pp.346-352.

Staedke S G, Mwebaza N, Kamya M R, Clark T D, Grant D, Rosenthal P J, and Whitty C J.M. (2009). Home management of malaria with artemether-lumefantrine compared with standard care in urban Ugandan children: a randomised controlled trial. The Lancet, 373(9675), pp.1623-1631. 
Stephens J, and Maiso G W. (2012). Project of Support for the Preparatory Phase of the Uganda National Action Plan for the Elimination of Child Labour (SNAP Uganda). Geneva: ILO. Available at: https://www.ilo.org/ievaldiscovery/\#a2d44y.

Stolyarenko K. (2017). Youth Entrepreneurship Facility in Uganda. Geneva: ILO, pp.1. Available at: https://www.ilo.org/ievaldiscovery/docs/glossary.pdf.

Strzepek K, Boehlert B, Willwerth J, and Neumann J. (2016). The Contribution of Water Resources Development and Environmental Management to Uganda's Economy. Kampala: Industrial Economics, Incorporated, pp.87. Available at: vdocuments.mx_thecontribution-of-water-resources-development-and-2017-06-20-technology-mit.pdf.

Subhash C Seth. (2009). Implementation Completion and Results Report for Uganda - First Phase of the Road Development Program Project. Washington, D.C: World Bank, pp.57. Available at:

http://documents1.worldbank.org/curated/en/878921468316472255/pdf/ICR9070UGA NDA010Disclosed0031051091.pdf.

Sue L, Carruth M H, Nitkin T, and Akulo L. (2013). Final evaluation report: Lira District child survival project in Uganda. Washington, D.C: USAID, pp.251. Available at: https://pdf.usaid.gov/pdf_docs/PBAAA337.pdf.

Sundberg M, Petrucci F, and Lovasz J. (2015). Joint Evaluation of Budget Support to Uganda. Washington, D.C: World Bank, pp.101. Available at: http://www.oecd.org/derec/worldbankgroup/Strategic-evaluation-cooperation-ec-bsuganda.pdf.

Talisuna A O, Daumerie P G, Balyeku A, Egan T, Piot B, Coghlan R, and Kato F. (2012). Closing the access barrier for effective anti-malarials in the private sector in rural Uganda: consortium for ACT private sector subsidy (CAPSS) pilot study. Malaria Journal, 11(1), pp.356.

Taqi S M, Kshirsagar V, and Jayawickrama M S. (2010). Implementation Completion and Results Report for Uganda - Second Phase of The Agricultural Research and Training Project. Washington, D.C: World Bank, pp.62. Available at: http://documents1.worldbank.org/curated/en/964731468177539355/pdf/ICR09510bo x0341010DIsclosed0July091.pdf.

Tchale H. (2009). Implementation Completion and Results Report for A Northern Uganda Social Action Fund. Washington, D.C: World Bank, pp.61. Available at: http://documents.worldbank.org/curated/en/417791468310732815/UgandaNorthern-Uganda-Social-Action-Fund-Project.

Technical Evaluation Reference Group. (2019). Prospective Country Evaluation Uganda 2019 Annual Country Report. Kampala: IDRC, pp.78. Available at: http://idrcuganda.org/evaluation.html.

Temsch R, and Marchich M. (2002). UNIDO programs funded by Austria to strengthen the leather sector in Uganda. New York: UNIDO, pp.90. Available at: http://www.oecd.org/countries/uganda/35480777.pdf. 
Terberger E, and Große-Rüschkamp A Ayoki M. (2007). Country Programme Evaluation Uganda - Priority Area Financial Sector Development summary version of the Evaluation. Bonn: Federal Ministry for Economic Cooperation and Development (BMZ) , pp.11. Available at: http://www.oecd.org/countries/uganda/40952322.pdf.

Thery A S, and Ogwang J. (2005). Income Generation and Sustainable Livelihood Programme: Outcome Evaluation Final Report. New York: United Nations Development Programme. Available at: https://erc.undp.org/evaluation/documents/detail/288.

Thomson A. (2005). Uganda's Plan for Modernisation of Agriculture (2005/06). Copenhagen: Danida, pp.96. Available at: http://www.oecd.org/countries/uganda/35992588.pdf.

Thorne S, and Mutesasira L K. (2002). Uganda Photovoltaic Pilot Project for Rural Electrification UPPPRE UGA/97/G32. New York: United Nations Development Programme, pp.48. Available at: https://eartheval.org/sites/ceval/files/evaluations/70\%20Photovoltaic\%20Pilot\%20Proj ect\%20for\%20Rural\%20Electrification\%20\%28UPPPRE\%29\%20Uganda.pdf.

Tobian A A. R, Kigozi G, Redd A D, Serwadda D, Kong X, Oliver A, Nalugoda F, Quinn T C, Gray $\mathrm{R} H$, and Wawer M J. (2012). Male Circumcision and Herpes Simplex Virus Type 2 Infection in Female Partners: A Randomized Trial in Rakai, Uganda. The Journal of Infectious Diseases, 205(3), pp.486-490.

Tobian A A.R, Kong X, Wawer M J, Kigozi G, Gravitt P E, Serwadda D, Eaton K P, Nalugoda F, Quinn T C, and Gray R H. (2011). Circumcision of HIV-Infected Men and Transmission of Human Papillomavirus to Female Partners: Analyses of Data from a Randomised Trial in Rakai, Uganda. The Lancet Infectious Diseases, 11(8), pp.604-612.

Tobian A R, Gaydos C, Gray R H, Kigozi G, Serwadda D, Quinn N, Grabowski M K, Musoke R, Ndyanabo A, Nalugoda F, Wawer M J, and Quinn T C. (2013). Male circumcision and mycoplasma genitalium infection in female partners: A randomised trial in rakai, Uganda. Sexually Transmitted Infections, 90(2), pp.150-154.

Todd B, Wanda K, and Mugarura S. (2008). An Assessment of the Likely Impact on Ugandan Households of Rising Global Food Prices. Washington, D.C: International Food Policy Research Institute (IFPRI), pp.56. Available at: http://www.ifpri.org/publication/assessment-likely-impact-ugandan-households-risingglobal-food-prices.

Tropical Health LLP. (2016). Evaluation (phase II) of the universal coverage campaign for long-lasting insecticidal nets in Uganda: assessing effectiveness, efficiency and impact of the mass Ilin distribution. Washington, D.C: USAID, pp.151. Available at: https://pdf.usaid.gov/pdf_docs/PA00MFPQ.pdf.

Tsai A C, and Venkataramani A S. (2015). The causal effect of education on HIV stigma in Uganda: evidence from a natural experiment. Social Science \& Medicine, 142, pp.3746. 
Tsekpo A, and Hudson A. (2019). Parliamentary Strengthening and the Paris Principles: Uganda case study. London: Oversease Development Institute, pp.40. Available at: https://www.google.com/url?sa=t\&rct=j\&q=\&esrc=s\&source=web\&cd=82\&ved=2ahUK EwjD_ueWItrIAhVFtHEKHUKyDLk4UBAWMAF6BAgAEAI\&url=https\%3A\%2F\%2Fwww.odi .org\%2Fsites\%2Fodi.org.uk\%2Ffiles\%2Fodi-assets\%2Fpublications-opinionfiles\%2F4424.pdf\&usg=AOvVaw2Eghda0jLmZkIOL_kzpBgB.

Tumwebaze H, Tumwesigye E, Baeten J M, Kurth A E, Revall J, Murnane P M, and Celum C. (2012). Household-Based HIV Counseling and Testing as a Platform for Referral to HIV Care and Medical Male Circumcision in Uganda: A Pilot Evaluation. PLoS ONE, 7(12), pp.e51620.

Tusiime H, Robrecht R, and Lodewijk S. (2013). Food aid and household food security in a conflict situation: Empirical evidence from Northern Uganda. Food Policy, 43, pp.14-22.

Tylleskar T, Debra J, Meda N, Ingunn M, Engebretsen S, Chopra M, Abdoulaye H D, Tanya D, Ekstrom E C, Fadnes L T, Goga A, Kankasa C, Klungsoyr J I, Lombard C, Nankabirwa V, Nankunda J K, Van de-Perre P, Sanders D, Shanmugam R, Sommerfelt H, Wamani H, and Tumwine J K. (2011). Exclusive breastfeeding promotion by peer counsellors in sub-Saharan Africa (PROMISE-EBF): a cluster-randomised trial. Lancet, 378(9798), pp.420-427.

Uganda Human Rhites Commission. (2016). Irrational Justice: Mob Justice as a human right concern in Uganda. Kampala: Uganda Human Rights Commission, pp.74. Available at: uhrc.ug/irrational-justice-mob-action-human-rights-concern-uganda.

Uganda Human Rights Commission. (2017). Land Disputes and Human Rights in Selected Regions of Uganda: Tracing the Nexus. Kampala: Uganda Human Rights Commission. Available at: https://www.uhrc.ug/?page_id=1142.

UNFPA. (2018). Evaluation of UNFPA support to the prevention of, response to and elimination of gender-based violence and harmful practices (2012-2017). New York: UNFPA, pp.120. Available at: https://www.google.com/url?sa=t\&rct=j\&q=\&esrc=s\&source=web\&cd=1\&ved=2ahUKE wjDoqy6hNvIAhUBbFAKHY0aD7UQFjAAegQIBRAC\&url=https\%3A\%2F\%2Fwww.unfpa.o rg\%2Fsites\%2Fdefault\%2Ffiles\%2Fadminresource\%2FGBV_Report_FINAL_29_Nov.pdf\&usg=AOvVaw1ikjoW5FXOk4BFcfVtbQCf.

Vaillancourt D. (2006). Project performance assessment report for Uganda - District Health Services Pilot and Demonstration Project. Washington, D.C: World Bank, pp.93. Available at: http://documents1.worldbank.org/curated/en/316011468310727777/pdf/357960rev0 pdf.pdf.

Vaillancourt D. (2005). Project performance assessment report for Uganda - Sexually Transmitted Infections Project. Washington, D.C: World Bank, pp.84. Available at: http://documents1.worldbank.org/curated/en/202701468177540145/pdf/32600.pdf.

Valadez J, Jeffery C, Brant T, Vargas W, and Pagano M. (2015). Final Impact Assessment of the Results-Based Financing Programme for Northern Uganda. Liverpool: Liverpool 
School of Tropica Medicine, pp.107. Available at:

https://assets.publishing.service.gov.uk/government/uploads/system/uploads/attach ment_data/file/607579/Evaluation-of-Results-Based-Financing-Programme-forNorthern-Uganda.pdf.

Van D H D. (2003). Results of International Debt Relief 1990-1999 with case studies of Bolivia, Jamaica, Mozambique, Nicaragua, Peru, Tanzania, Uganda and Zambia. Hague: IOB, pp.225. Available at: http://www.oecd.org/countries/jamaica/35149431.pdf.

Verena E, Pfeiffer A, Schauer E, Elbert T, and Neuner F. (2011). Community-Implemented Trauma Therapy for Former Child Soldiers in Northern Uganda A Randomized Controlled Trial: DFG (Deutsche Forschungsgemeinschaft) and the Ein Herz fur Kinder foundation.

Verspoor A M, Nannyonjo H, and Bertoncino C. (2001). Implementation completion report for Uganda - Education Sector Adjustment Operation Project. Washington, D.C: World Bank, pp.63. Available at:

http://documents.worldbank.org/curated/en/457841468121756735/Uganda-

Education-Sector-Adjustment-Operation-Project.

Waelkens M P. (2009). Care for people living with disabilities in the west Nile region of Uganda: Ex-post evaluation of a programme implemented by doctors with Africa Cuamm. UMU Press, 7(3), pp.180-198.

Wagle D. (2015). Implementation Completion and Results Report for A Uganda-Financial Sector Development Policy Credit. Washington, D.C: World Bank, pp.48. Available at: http://documents1.worldbank.org/curated/en/791081468103474064/pdf/ICR31390P1 17970C0disclosed010300150.pdf.

Wagman J A, Gray R H, Campbell J C, Thoma M, Ndyanabo A, Ssekasanvu J, Nalugoda F, Kagaayi J, Nakigozi G, Serwadda D, and Brahmbhatt H. (2014). Effectiveness of an integrated intimate partner violence and HIV prevention intervention in Rakai, Uganda: analysis of an intervention in an existing cluster randomised cohort. The Lancet Global Health, 3(1), pp.23-33.

Waiswa P, Pariyo G, Kallander K, Akuze J, Namazzi G, Ekirapa K E, Kerber K, Sengendo H, Aliganyira P, Lawn J E, and Peterson S. (2015). Effect of the Uganda Newborn Study on care-seeking and care practices: a cluster-randomised controlled trial. Glob Health Action, 8, pp.24584-24584.

Walakira E J, Muhangi D, Murokora D, Ssengendo J E, and Kayiwa J. (2015). Performance evaluation of USAID/Uganda's 2009-2014 STRIDES for family health program. Washington, D.C: USAID, pp.96. Available at: https://pdf.usaid.gov/pdf_docs/PA00KS5M.pdf.

Walker D, Muyinda H, Foster S, Kengeya-Kayondo J, and Whitworth J. (2001). The quality of care by private practitioners for sexually transmitted diseases in Uganda. Health Policy and Planning, 16(1), pp.35-40. 
Wally H. (2015). Final Evaluation of the Avian and Human Influenza Preparedness and Response Project (AHIP). Washington, D.C: World Bank, pp.11. Available at: http://documents.worldbank.org/curated/en/660961475114036848/UgandaPreparedness-And-Control-Of-Avian-Influenza.

Wambugu L, and Getachew A. (2008). Rights of Children in Conflict An Evaluation of Japanese Official Development Assistance in Acholiland, Northern Uganda. Addis Ababa: Institute for Security Studies, pp.60. Available at:

https://www.africaportal.org/publications/rights-of-children-in-conflict-an-evaluationof-japanese-official-development-assistance-in-acholiland-northern-uganda/.

Wambui G. (2003). Implementation completion report for Uganda - Small Towns Water and Sanitation Project. Washington, D.C: World Bank, pp.55. Available at: http://documents1.worldbank.org/curated/en/213081468761352553/pdf/275290UG.pdf

Wandwasi P. (2017). Meta-evaluation of world bank evaluations of poverty reduction interventions in Uganda.

Wanyama J, Ssegane H, Kisekka I, Komakech A J, Banadda N, Zziwa A, Ebong T O, Mutumba C, Kiggundu N, Kayizi R K, Mucunguzi D B, and Kiyimba F L. (2017). Irrigation Development in Uganda: Constraints, Lessons Learned, and Future Perspectives. American society of civil engineers, 143, pp.04017003.

Wanyama J N, Castelnuovo B, Gavin R, Newell K, Sempa J B, Kambugu A, Manabe Y C, and Colebunders R. (2012). A Randomized Controlled Trial to Evaluate the Effectiveness of a Board Game on Patients' Knowledge Uptake of HIV and Sexually Transmitted Diseases at the Infectious Diseases Institute, Kampala, Uganda. JAIDS Journal of Acquired Immune Deficiency Syndromes, 59(3), pp.253-8.

Wanyenze R K, Atuyambe L, Kibirige V, Mbabazi S, Tumwesigye N M, Djurhuus K, and Namale A. (2011). The new female condom (FC2) in Uganda: perceptions and experiences of users and their sexual partners. African Journal of AIDS Research, 10(3), pp.219-224.

Wanyenze R K, Hahn J A, Liechty C A, Ragland K, Ronald A, Mayanja-Kizza H, Coates T, Kamya M R, and Bangsberg D R. (2011). Linkage to HIV care and survival following inpatient HIV counseling and testing. AIDS Behavior, 15(4), pp.751-760.

Wanyenze R K, Kamya M R, Fatch R, Mayanja-K H, Baveewo S, Szekeres G, Bangsberg D R, Coates T, and Hahn J A. (2013). Abbreviated HIV counselling and testing and enhanced referral to care in Uganda: a factorial randomised controlled trial. LANCET, 1(3), pp.PE137-E145.

Wanyenze R K, Wagner G, Alamo S, Amanyire G, Ouma J, Kwarisima D, Sunday P, Mangen F W, and Kamya M. (2010). Evaluation of the Efficiency of Patient Flow at Three HIV Clinics in Uganda. AIDS Patient Care and STDs, 24(7), pp.441-446.

Ware N C, Pisarski E E, Nakku-Joloba E, Wyatt M A, Muwonge T R, Turyameeba B, and Katabira E T. (2018). Integrated delivery of antiretroviral treatment and pre-exposure 
prophylaxis to HIV-1 serodiscordant couples in East Africa: a qualitative evaluation study in Uganda. Journal of International Aids Society, 21(5), pp.e25113.

Watts C, Devries K, Kiss L, Abramsky T, Nambusi K, and Lori M. (2015). The SASA Study: A Cluster Randomised Controlled Trial to Assess the Impact of a Violence and HIV Prevention Programme in Kampala, Uganda. New Delhi: International Initiative for Impact Evaluation (3ie), pp.44. Available at:

http://www.3ieimpact.org/sites/default/files/2019-01/ie_24-sasa_KCUd1B7.pdf.

Wawer M J, Makumbi F, Kigozi G, Serwadda D, Watya S, Nalugoda F, Buwembo D, Ssempijja V, Kiwanuka N, Moulton L H, Sewankambo N K, Reynolds S J, Quinn T C, Opendi P, Iga B, Ridzon R, Laeyendecker O, and Gray R H. (2009). Circumcision in HIV-Infected Men and its Effect on HIV Transmission to Female Partners in Rakai, Uganda: A Randomised Controlled Trial. Lancet, 374(9685), pp.229-237.

Wawer M J, Makumbi F, Kigozi G, Serwadda D, Watya S, Nalugoda F, Buwembo D, Ssempijja V, Kiwanuka N, Moulton L H, Sewankambo N K, Reynolds S J, Quinn T C, Opendi P, Iga B, Ridzon R, Laeyendecker O, and Gray R H. (2009). Circumcision in HIV-Infected Men and its Effect on HIV Transmission to Female Partners in Rakai, Uganda: A Randomised Controlled Trial. The Lancet, 374(374), pp.229-237.

Wawer M J, Tobian A A.R, Kigozi G, Kong X, Gravitt P E, Serwadda D, Nalugoda F, Makumbi F, Ssempiija V, Sewankambo N, Watya S, Eaton K P, Oliver A E, Chen M Z, Reynolds S J, Quinn T C, and Gray R H. (2011). Effect of circumcision of HIV-negative men on transmission of human papillomavirus to HIV-negative women: a randomised trial in Rakai, Uganda. The Lancet, 377(9761), pp.209-218.

Weaver M R, Burnett S M, Crozier I, Kinoti S N, Kirunda I, Mbonye M K, Naikoba S, Allan R, Rubashembusya T, Zawedde S, and Willis K S. (2014). Improving Facility Performance in Infectious Disease Care in Uganda: A Mixed Design Study with Pre/Post and Cluster Randomized Trial Components. PLOS ONE, 11(1), pp.e0148672..

Webber A D, Hill C M, and Reynolds V. (2007). Assessing the failure of a community-based human-wildlife conflict mitigation project in Budongo Forest Reserve, Uganda. Oryx, 41(2), pp.177-184.

Week J, Andersson D, Cramer C, Geda A, Hailu D, Muhereza F, Rizzi M, Ronge E, and Stein H. (2002). Supporting Ownership, Swedish Development Cooperation with Kenya,Tanzania and Uganda (Volume II: Country Studies). Stockholm: Sida, pp.252. Available at: http://www.oecd.org/countries/tanzania/35203817.pdf.

Weidle P J, Malamba S, Mwebaze R, Sozi C, Rukundo G, Downing R, Samb B 2002). Assessment of a pilot antiretroviral drug t, a: patients' response, survival, and drug resistance The Lancet. (2002). Assessment of a pilot antiretroviral drug therapy programme in Uganda: patients' response, survival, and drug resistance. The Lancet, 360 (9326), pp.34-40.

Weier J N. (2002). Uganda - Protected Areas Management and Sustainable Use Project. Washington D.C.: World Bank, pp.94. Available at: 
http://documents1.worldbank.org/curated/en/525121468778177363/pdf/multiOpage. pdf.

Weingärtner L, Hoerz T, and Kitanda R. (2011). German Humanitarian Aid Abroad - Uganda Country Study. Bonn: Federal Ministry for Economic Cooperation and Development (BMZ). Available at: http://www.oecd.org/countries/uganda/49865099.pdf.

Were M C, Shena C, Bwanab M, Emenyonuc N, Musinguzi N, Nkuyahagad F, Kembabazi A, and Tierney W M. (2010). Creation and evaluation of EMR-based paper clinical summaries to support HIV-care in Uganda, Africa. International Journal of Medical Informatics, 79(2), pp.90-96.

Wielders I, and Amutjojo LJ. (2012). Final evaluation report of UN Peacebuilding Fund programmes in Acholiland, Northern Uganda. New York: United Nations Development Programme (UNDP), pp.78. Available at:

https://erc.undp.org/evaluation/documents/detail/6963.

Williams S, and Khaukha S. (2012). Terminal Evaluation-Conservation of The Biodiversity in The Albertine Rift Forests of Uganda. New York: United National Development Program (UNDP), pp.74. Available at: https://erc.undp.org/evaluation/documents/detail/7145.

Williams S, and Ngubwagye J M. (2016). Conservation and sustainable use of threatened savannah woodlands in the Kidepo Critical Landscape in North Eastern Uganda. New York: United Nations Development Programme (UNDP), pp.115. Available at: https://erc.undp.org/evaluation/documents/detail/9620.

Wilson L E, Gravitt P, Tobian A A.R, Kigozi4 G, Serwadda D, Nalugoda F, Watya S, Wawer M J, and Gray R H. (2013). Male circumcision reduces penile high-risk human papillomavirus viral load in a randomised clinical trial in Rakai, Uganda. BMJ Journals, 89(3), pp.262-6.

Witter S, Kardan A, Scott M, and Moore L. (2015). Independent Evaluation of the DemandDriven Impact Evaluations for Decisions (3DE) Pilot. London: DFID, pp.164. Available at: http://www.oecd.org/derec/unitedkingdom/Demand-Driven-Impact-EvaluationsDecisions-3DE-Pilot.pdf.

Wolff B, Nyanzi B, Katongole G, Ssesanga D, Ruberantwari A, and Whitworth J. (2005). Evaluation of a home-based voluntary counselling and testing. Health policy and planning, 20(2), pp.109-116.

Wong M D. (2003). Implementation completion report for Uganda - Private Sector Competitiveness Project. Washington, D.C: World Bank, pp.30. Available at: http://documents.worldbank.org/curated/en/969071468761054723/Uganda-PrivateSector-Competitiveness-Project.

Wydick B, Glewwe P, and Rutledge L. (2013). Does International Child Sponsorship Work? A Six-Country Study of Impacts on Adult life outcomes. Journal of Political Economy, 121, No. 2(2), pp.393-436. 
Yang H, and Daly J. (2007). Implementation completion and results report for Uganda Decentralized Services Delivery: a Makerere University Training Pilot Project. Washington, D.C: World Bank, pp.73. Available at: http://documents.worldbank.org/curated/en/890221468318018857/UgandaDecentralized-Services-Delivery-a-Makerere-University-Training-Pilot-Project.

Yawe B. (2010). Hospital Performance Evaluation in Uganda: A Super-Efficiency Data Envelope Analysis Model. Zambia Social Science JournaL, 1(1), pp.28.

Ybarra M L, Bull S S, Korchmaros J D, Bangsberg D R, and Kiwanuka J P. (2013). Adolescent Abstinence and Unprotected Sex in CyberSenga, an Internet-Based HIV Prevention Program: Randomized Clinical Trial of Efficacy. PLoS ONE, 8(8), pp.e70083.

Ybarra M L, Korchmaros J D, Prescott T L, and Birungi R. (2015). A Randomized Controlled Trial to Increase Hiv Preventive Information, Motivation, And Behavioral Skills in Ugandan Adolescents. Annals of Behavioral Medicine, 49(3), pp.473-485.

Yitzhak A K, Asebe E, and Riverson J D. (2001). Implementation completion report for Uganda - Transport Rehabilitation Project. Washington, D.C: World Bank, pp.51. Available at: http://documents.worldbank.org/curated/en/826081468317109626/UgandaTransport-Rehabilitation-Project.

Zeitlin A, Bategeka L, Guloba M, Kasirye I, and Mugisha F. (2011). Management and motivation in Ugandan primary schools: Impact evaluation final report. London: Centre for the Study of African Economies, University of Oxford, pp.42. Available at: http://www.iig.ox.ac.uk/output/reports/pdfs/iiG-D10UgandaPrimarySchoolsImpactReportFinal.pdf.

Zeljko B, and Moritz P. (2015). Project Performance Assessment Report for Uganda- FifthNinth Poverty Reduction Support Credits 5-7. Washington, D.C: World bank, pp.136. Available at:

http://documents1.worldbank.org/curated/en/942871468188377758/pdf/96202-PPARP090881-P090219-P101231-P101232-P097325-Box385353B-OUO-9-IDA-SecM20150150.pdf.

Zemedkun G. (2012). Implementation Completion and Results Report for Uganda-Road Development Program, Phase III. Washington, D.C: World Bank, pp.70. Available at: http://documents1.worldbank.org/curated/en/837001468349792374/pdf/ICR21850P0 740700fficila0Use0ONly090.pdf.

\section{Funding}

This map has been funded by the Campbell Collaboration and a grant from the Foreign, Commonwealth and Development Office under the Centre of Excellence for Development Impact and Learning (CEDIL). 


\section{Plans for updating the EGM}

No funding is currently available for this purpose. It will be sought once the map is published. 
in Centre of Excellence for Development Impact 